Historic, Archive Document

Do not assume content reflects current scientific knowledge, policies, or practices. 



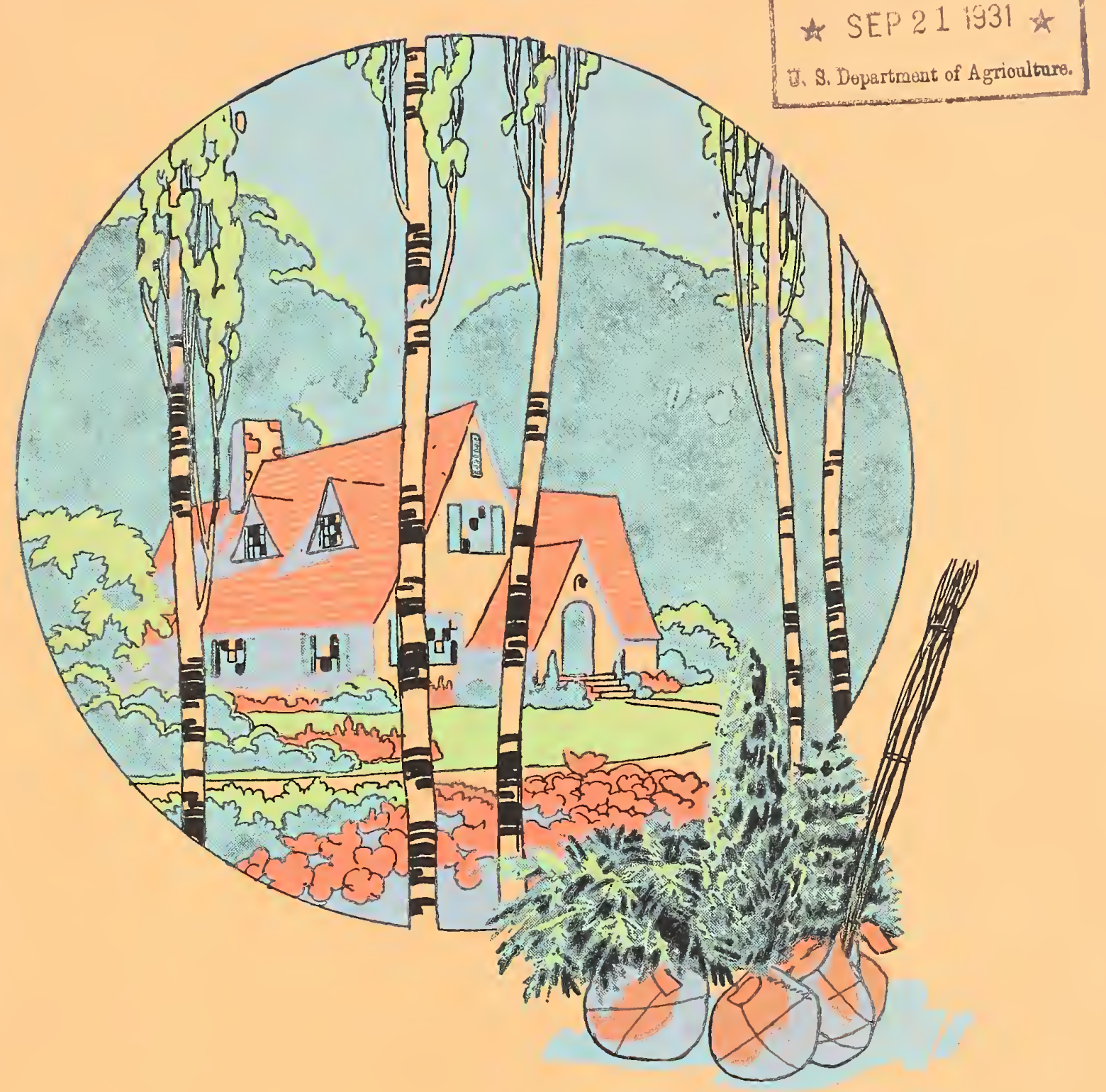

\section{HILLENMEYER N URS ERIES}




\section{A \\ MESSAGE FROM THE \\ HILLENMEYERS}

We know you will like our new Catalog. This one tells you How, When and What to plant. It contains cultural directions, pruning instructions, planting lists and many things of horticultural interest from cover to cover.

This catalog is our only

salesman. We have no agents. You buy direct and save.

Our prices are greatly reduced this year. When you see the fine bushy, well trained specimens with their superior root systems you will realize you are getting real bargains in quality as well as cost. Price is only part of the cost, for actual results are what you purchase when buying nursery stock. As a careful buyer, we know you will be pleased with our plants from the standpoint of cost, quality and dependability.

We are appreciative of your past patronage and we are happy to say we are in position to serve you better and more liberally than ever before.

\section{HILLENMEYER NURSERIES}

\section{LEXINGTON, KENTUCKY}

LOUIS E. HILLENMEYER

WALTER W. HILLENMEYER

FALL 1931-SPRING 1932 


\section{LOWEST PRICES IN YEARS}

\section{Take a tip from} Hillenmeyer

\section{Buy while prices} are down
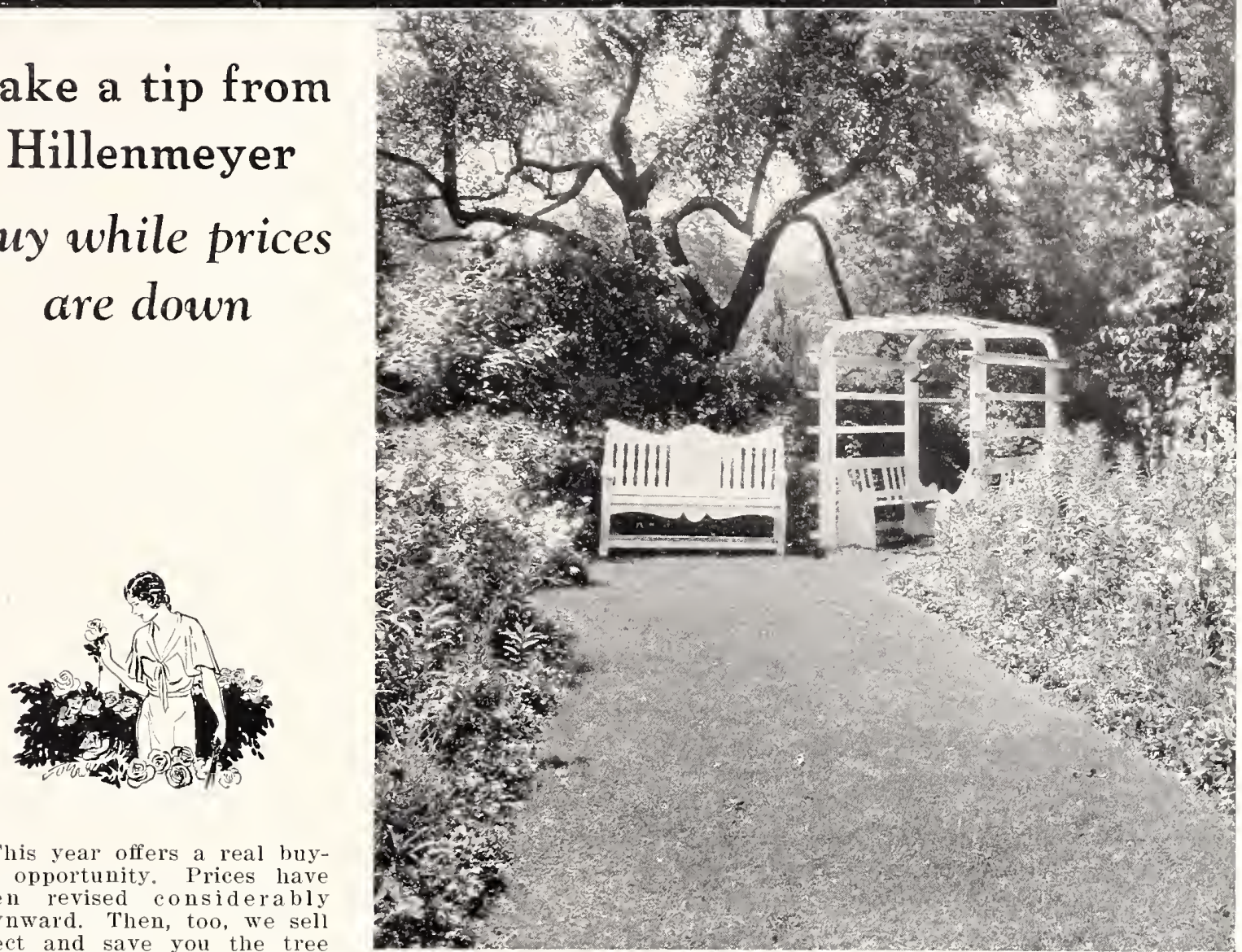

This year offers a real buying opportunity. Prices have been revised considerably downward. Then, too, we sell direct and save you the tree agent's commission.

This is your chance to buy superior nursery stock at prices that compare favorably with those more often asked for inferior stock. We know our plants have the vitality, not surpassed by any offered. They are produced on the most fertile of Blue Grass land, dug fresh, packed carefully, and guaranteed to reach you in prime condition or yomr money back.

\section{Nursery Stock a Good Investment}

Is there any other thing about your home that grows in value, interest and beanty each succeeding. year like trees and plants? Most other things are wearing out with use and age and constantly depreciating in value. That is why we say our nursery stock is a permanent and accumulative investment. What is that shade tree that cost you two or three dollars a few years ago now worth to your place? If you are contemplating a planting, not for years have you had such an unusual opportunity to secure plants of Hillenmeyer quality at such low prices.

\section{BUDGET PAYMENTS}

We are willing to co-operate further in the way of extending credits. The planting season comes in fall and spring and if your planting is not done then. a year's delay is experienced. We will help those of our patrons who can give satisfactory references by handling their purchases on liberal terms of payment. Write us for details.

\section{M P O R T A N T}

We have no fight with reputable nurseries selling through agents. They pay them big commissions. while we feel we can save you money by selling direct. We have

\section{NO AGENTS.}

If you must buy through agents be sure they represent an established firm. Thousands of dollars are wasted annually in Kentucky on stock from tree swindlers who set up a mere name of a nursery and sell anything at any price. They are gone in a season and their guarantees and promises vanish with them. A reliable nursery does not have to resort to such tactics. Our representative will call by appointment but we do not make a house to house canvass. You must be the judge of what you buy or get it from reliable sources. We have no transient agents, whether they say so or not. 


\section{Visit Our MODERN NURSERY}

We invite you to drive out and nay us a visit. We are not boasting when we say we have two hundred and fity acres of as fine nursery stock as we have ever grown. We would like tor you to see our place. It is organized tor efficient production and delivery ot dependable stock. An inspection of our nursery will convince you of its completeness and variety.

The growing season is the ideal time to see things in color, leat and fruit. Other seasons offer particular interesting sights. We will be pleased to talk over your planting problems, assist you with your selection or give you any horticultural intormation we can. We are always glad to see you. Visit us when convenient

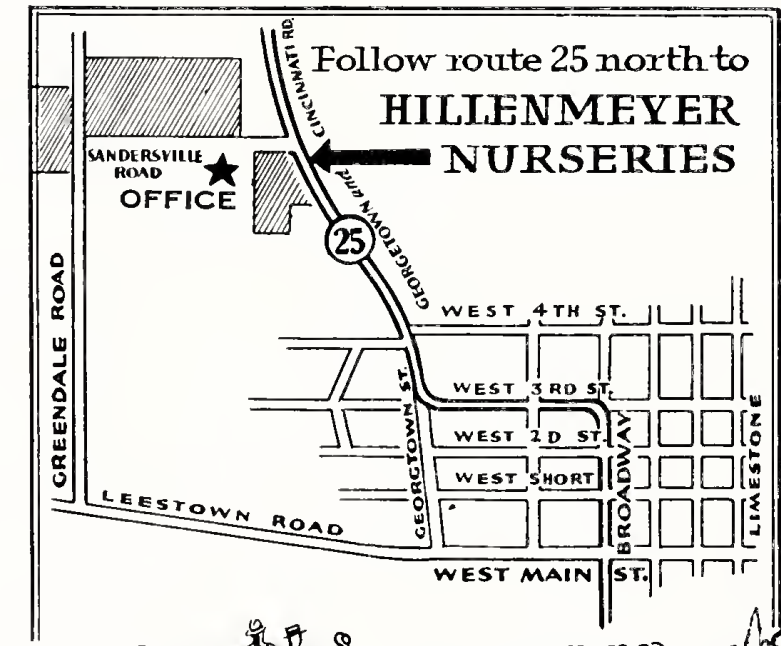

\section{SELECT YOUR PLANTS RIGHT AT THE NURSERY}

Our office grounds have mally specimens that are of particular interest to any purchaser of nursery stock. Here you can compare their various characteristics. Then, too, our many acres of growing plants are interesting at all seasons. We invite your personal inspection and selection of plants. If you will visit us we can give you much information about varieties and planting not possible otherwise.

During the planting season we maintain a corps of helpers who will get your order out while you wait. This insures you of fresh plants, full of vitality, and if planted at once are sure to grow.

\section{HOW TO REACH US}

We are located just twelve minutes from the heart ot Lexington, or a mile and a half from the city limits. Take Georgetown-Cincinnati Road (U. S. No. 25, commonly called the Dixie Highway) and one mile from the city limits you will find our BRANCH NURSERY. (By interurban you are fifteen minutes to Station No. 7.) Turn in at the Sandersville Road-our offices, sales grounds and warehouse are located a short distance trom the main road. We will be pleased to show you our place.

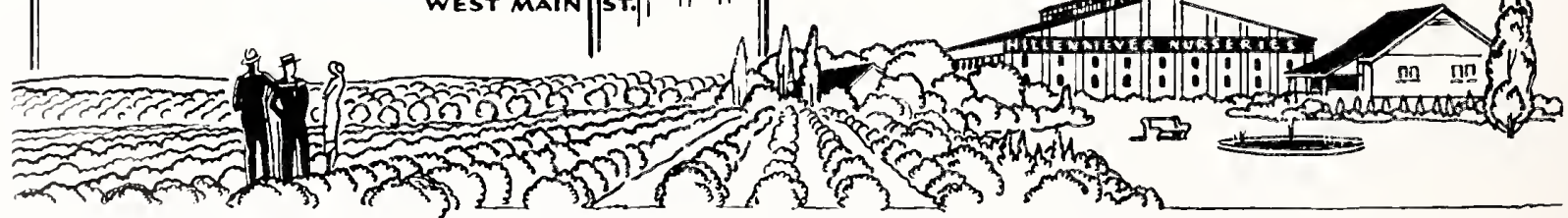

In addition to our nursery there are many histuric spots of interest in and around Lexington well worth seeing. 
NOW!

\section{Hillenmeyer Of- fers More inValue and Service than Ever Before ...}

VALUEs. We mention on the first page something of our unusual values this year. This is not alone in price but in quality at that price. Ask about our Budget Payment Plan.

ORDER Filily. Early ordering enables us not only to reserve for you choice plants but these early orders get first attention before unfavorable weather or before the "rush" begins. The planting season is limited to a few weeks and reservations made early get best service.

DELIVERY. Arrangements can be made for distant deliveries according to mileage and quantities. We deliver without additional charge to all local patrons within the city and the residential sections nearby.

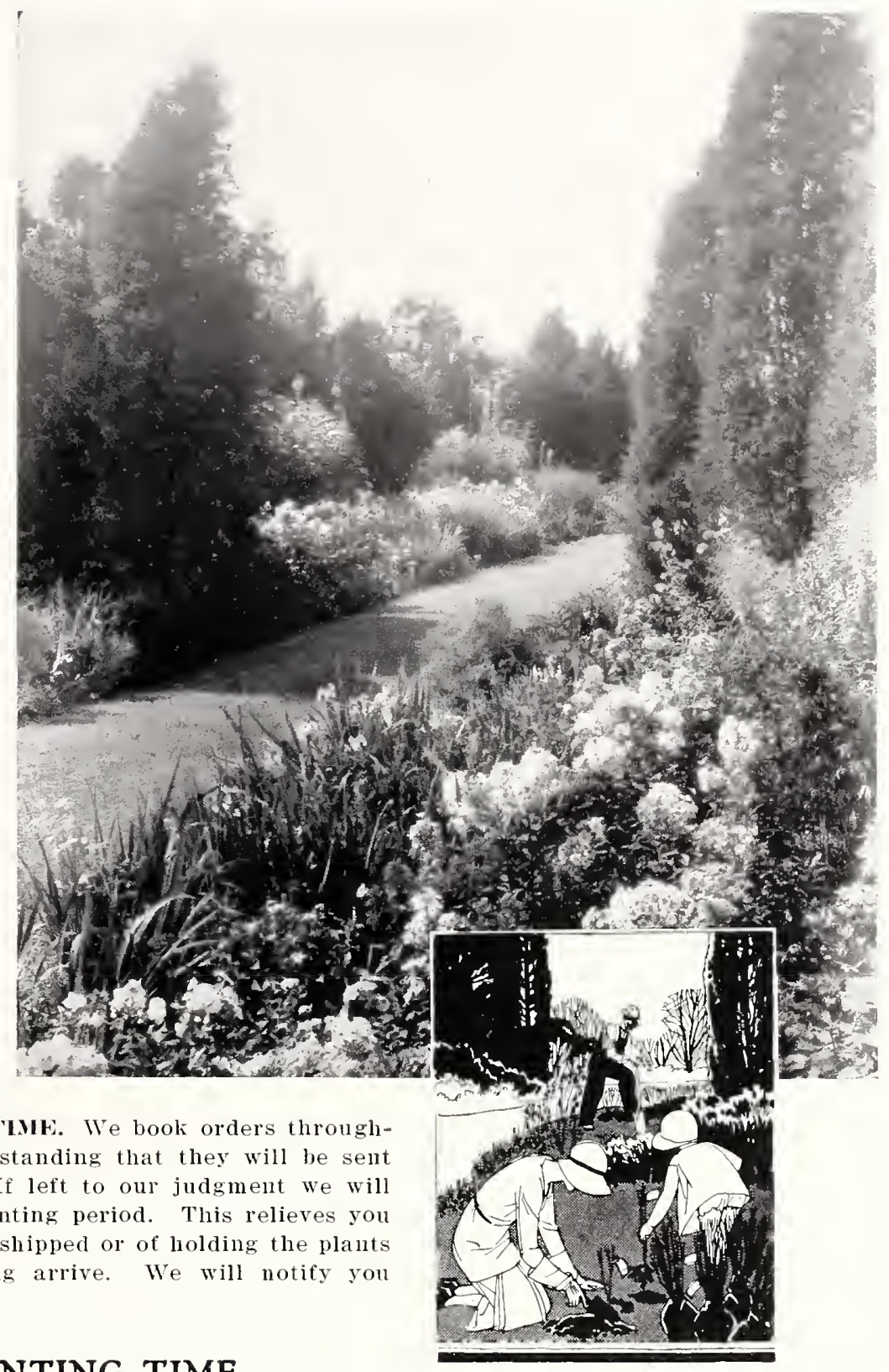

ORDERS SHIPPED AT RIGH'T TIME. We book orders throughout the entire year with the understanding that they will be sent at the "proper planting" season. If left to our judgment we will see that they arrive at the best planting period. This relieves you of the worry of when to have them shipped or of holding the plants until proper conditions for planting arrive. We will notify you when shipment is made.

\section{THE BEST PLANTING TIME}

In the spring we are dependent on when the frost is out of the glound. The last of February or early March are the usual opening dates.

In the fall we need sufficient frost to stop growth and harden the wood. For deciduous stock rarely is this previous to October fitteenth. Perennials and evergreens can be planted earlier. In all events the calendar measures time but not planting conditions. Why not rely on us to send your order at the proper time?

To us, however, of most importance, is your success with plants. This depends not alone on the time they are planted but equally as much on the preparation of the soil to receive them, and the care in planting. First get your soil in best physical condition, properly enriching it if it needs it. Then when you receive your plants don't expose the roots longer than absolutely necessary. Put them right in the ground or protect them carefully and otherwise follow the planting instructions sent with each order.

\section{FREE HOW to PLANT Booklet}

WITH EVERY ORDER we mail a copy of a simple HOW TO PLANT BOOKLET. Written in understandable terms, you really cannot fail to have success witl your planting if you follow directions, Written for the novice and is fully illustrated. This is sent without charge as we spare no effort to make every order a satisfactory one. 


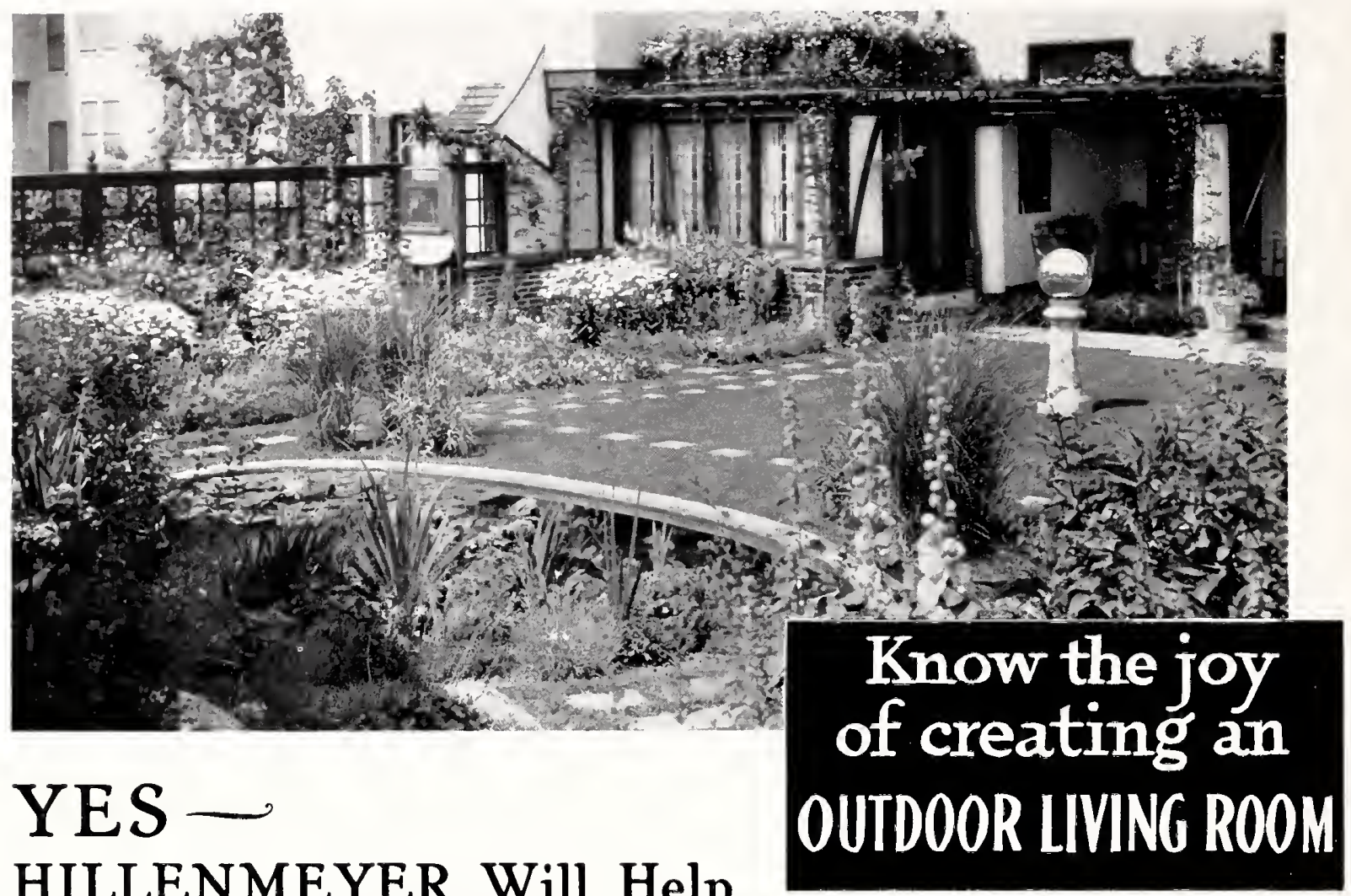

HILLENMEYER Will Help You Plan Your Grounds

$\mathrm{P}$

ROPER landscaping of one's place is recognized by all

as the real finishing touch of the home grounds. We have established a service designed to be of assistance to you.

\section{NO ACTUAL CHARGE for PLANS}

As an evidence of "good faith" we simply ask for a deposit of five dollars. This money is kept until you place your order, then it is credited to your account. In other words, your plans cost you nothing and the deposit arrangement gives us protection from "curiosity inquirers" Of local patrons we ask no deposit, reserving the privilege to charge for plans if the order isn't placed with us.

SUGGEsTioxs. Don't wait until it is time to plant before you call on us. If you forget it until you get the planting urge send in your measurements any way and if we cannot work out your plan, will then advise you.

Give all the ground dimensions, marking every angle, distance between windows, location of existing trees and walks, points of the compass and such
other matters of interest. Scale draw-
ings are not necessary kodak pictures

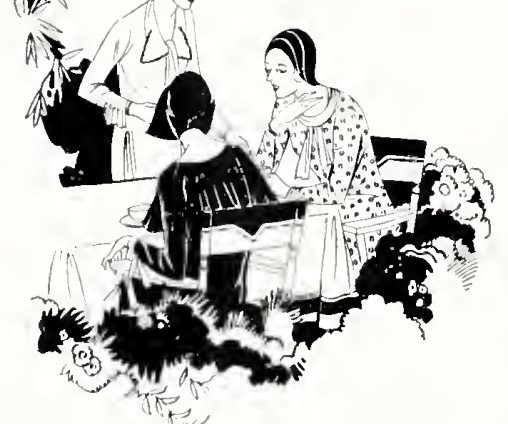
or architect's drawings a re invaluable in giving us an idea of what your place is like. Pools, gardens, rockeries, or any particular feature you wish incorporated should be mentioned. It will help if you give us an idea of what $y$ o u w is h to spend and your preference of plants, if you have any.
The Outdoor Living Room is a creation of the modem day. It is the vogue and fashion of the times. The back yard of yesteryear has passed and in its place we have-walls built of hedges or borders of living green, shade trees with their sheltering arms casting cooling shadows on the grassy carpet of the the great outdoors. Gay colored flowers adding their beauty, charm, and fragrance to this glorified Outdoor Room. Here, too, the walks of inviting stepping stones or grass lead past the sun dial, bird bath, or lily pool to convenient benches or garden furniture placed for the comfort of those who really enjoy things beautiful.

\section{NOW IS THE TIME TO PLAN}

Does your back yard present an uninviting picture? Why not create a modern Outdoor Living Room in its stead, where clildren may play fearless of the thundering traffic on the street; where Mother will find a charming spot for relaxation and entertainment; where Father, too, will bring his friends for it really is an inviting and inspiring place, cool and restful. This new room offers new pleasures and new charms to your home environment. To this add the indescribable happiness and enjoyment it will bring your family and friends.

These Outdoor Living Rooms grow in value, interest and beauty each succeeding year. Best of all they are not expensive provided you let Hillenmeyer do it. 


\section{DECORATIVE SHRUBS}

$\mathrm{T}$ HE ornamental shrub group includes all those deciduous, blooming, and berry-bearing, woody plants that are ordinarily called shrubs. They naturally cover a wide lange as to size, from vely low growing plants to those that are tall enough fol screens and wind breaks. In color of blossom, character of glowth. adaptability to soil, you will find something suited for every loca tion. They will put the finishing touches to your home grounds and your outdoor living room.

Some of the more unusual and distinctive slrubs we offer are illustrated and described on pages 25 to 28 . These outstanding varieties will bring new chal"m and interest to your garden for they are shrubs not often seen in general plantings. Add distintion to your shrub borders by planting some this year.

\section{How to Use This Shrub List}

The common names and technical names are both used.

(F) indicates those plants best suited for foundation or doorstep planting.

The height to which they grow is indicated immediately after the name, as: 1 to 2 feet, or, 5 to 6 feet.

You will notice that occasionally five plants of a particular size are specially priced. If you do not wish five of the same variety you may buy an assortment at that price, providing the grade of each plant is the same.

\section{Quantity Rates On All Shrubs}

These prices apply to any assortment.

5 of any $\$ .40$ size for.

5 of any $\$ .50$ size for

Larger sizes and quantity lots quoted on request.
$\$ 1.75$

$\$ 2.25$

\section{Abelia}

Melia crandiflora (Abelia). (F). 3 to 4 feet, white. July to Septemtractive of the broad-leaved evergreen shrubs. For full description

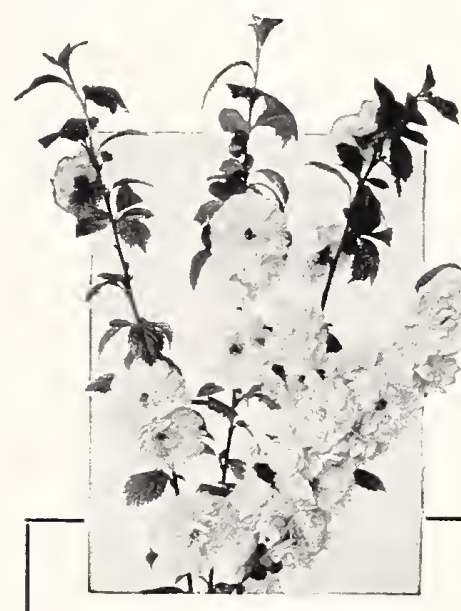

FLOWERING PEACH.

\section{GE N E R A I I Y}

lawn should be left open as it gives an air of spaciousness as well as neatness. Use shade trees to frame the lawn and house and to provide a background for the house. Shrubs along the borders will denote the property lines and screen out objectionable views. Evergreens or suitable shrubs for doorstep and foundation planting will frame the entrance and tie the house to the ground and give a harmonious effeet to the home lawn. And don't forget the rear lawn, make it an outdoor living room.

Tall shrubs in borders should be placed in the background and some of lower growing or dwarf habits planted in front. And don't make the background of long borders all the same skyline. Intersperse some taller growing trees or shrubs to add interest.
Aralia

eanthopamax pentaphyllum feet an unusually hardy shrub. oil in very adverse will grow under the shade fails. canes are inclinedive. The prickly and comparatively growth.

4 to 5 feet.....\$ .75 each 3 to 4 feet......\$.50 each

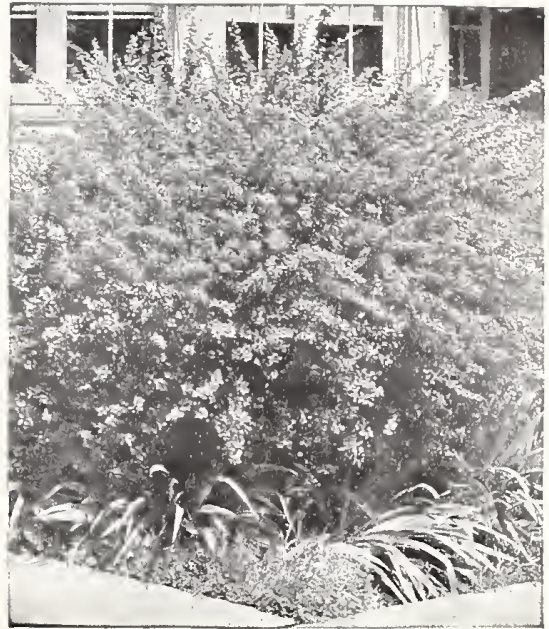

JAPANESE BARBERI:X See page 6.

Aralia spinosa (Hereules Club). 15 to 18 feet. A rather unusual shrub having white flowers in summer, followed by dark purple berries. Useful for tropical effects.

6 to 8 feet

$\$ 1.50$ each

Amygdalus - Flowering Peach

Inyedalus persica (Flowering Peach). We have these in both pink and red. These make small trees 15 feet and in April every twig and branch is brilliant with its beautiful flowers. One of the most attractive ornamental trees. Order to color.

4 to 5 feet.

.75 each

3 to 4 feet

50 each

\section{Aronia-Red Chokeberry}

Aronia arbutifolia (Red Chokeberry). Valuable because of its red berries and fall coloring. Grows in moist places and endures shade. White flowers in June.

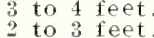

.75 each

Benzoin aestavalis - Spice Bush

Henzoin acstavalis (spiec Bush). This glows eight to ten feet with yellow flowers in March and April followed by scarlet berries. Colors beautifully in the autumn and leaves aromatic.

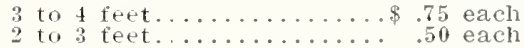

\section{Some Landscape Suggestions} Try to group three or more shrubs in a mass
planting, as alternating or variety planting often gives an undesirable effect.

Make your entrance walks direct on small properties. Curves in walks and roads, borders and beds are generally more pleasing where they can be used. Don't overdo curves but use them where you can.

Sticking a few trees and shrubs here and there is not landscaping or beautification. Too few are willing to study the picture before planting. It isn't hard for an amateur to get good effects with a little study. Stick stakes in the ground where you think you want trees, lay the hose down to mark the edge of a foundation or perennial border, then get off and study the arrangement and make changes to suit your ideas. Always remember you can't plant trees on rollers and push them around after planting. 


\section{Shrub Assortment Offer}

These prices appiy to any assortment. 5 of any $\$ 0$ size for $\$ 1.75$
of any 50 size for $\$ 2.25$
of any $\$ 75$ size for $\$ 3.25$

Latl'ger sizes and quantity lots quoted on request.

\section{Berberis-Barberry}

Herloris thumbersi atropnrpurea (ned heaved J a p a ese II:arberry. Full description on page 25 .

Herberis thumbergi (Japanese Harberry). (F). doubt is the most valuabe all-purpose shrub

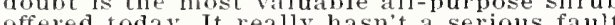
offered today. It really hasn t a serious fault and can be used wherever a plant of this size is desired. Grows in semi-shady moist or dry locations. When used as a specimen plant or as an edging plant for borders, foundations or hedges, its drooping habit, deep green foliage in the summer months and red berries that hang all winter, are attractive. We grow large quantities of this and umhesitatingly recommend it to every one who desires a hardy, thrifty plant that will adapt itself to soil conditions under most trying

$21 / 2$ feet

2 feet

sere Hedges, palse 3a.

Horberis vulgaris (Common or English bar b(r). 'I hs glows six to eight feet, is upright in habit, and has yellow flowers in Apr. Color's well in the fall and is planted for its attractive red fruits that persist all winter. The best berry bearing variety.

3 to 4 foet. \$ $\$ 50$ each ; 2 to 3 feet. .\$. 40 each

llepberis vuluaris atropurpurea (Purple Barleerry). ( $F)$. 4 to 6 feet. Yellow. May. An English variety; one of the most attractive foliage shrubs we have. Royal purple leaves appear in April and are soon followed by chrome yellow blossoms. The leaves hold color well until fall. The clustered berries common to all Barberry are bright red and usually adhere well into the winter. For group or border planting when used el masse it is very desirable. For foundation, is without a peer.

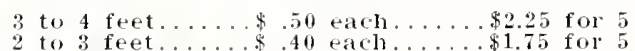

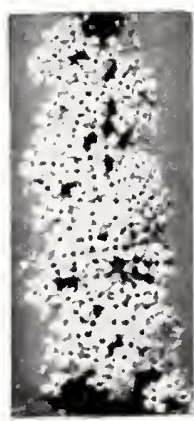

\section{Buddleia - Butterfly Bush} lludaleia davidi rllurerfl Bush or summer Lilac). 4 to 6 feet. Violet. July-September. A very attractive new addition to the flowering plants. While a perennial in habit, yet because of its vigor and size, it is used largely in shrub plantings. The tops in severe winter will freeze back, but it pushes with such renewed vigor this is not harmful. The flowers are borne on the tips of every bit of new growth, and in August the plants are masses of very let flowers that attract butterflies.

TTEREL
JUSII.

3 to 4 feet

\section{$\$ .50$ each}

$\$ 2.25$ for 5

\section{Callicarpa-Beautyberry}

Callicarpa mronrea (Besutyberry). 3 feet Pink-tinted blossoms in August followed by clusters of violet-purple berries. Perennia -in that it frequently is winter killed, but comes again.

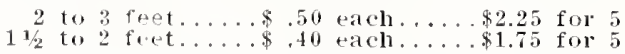

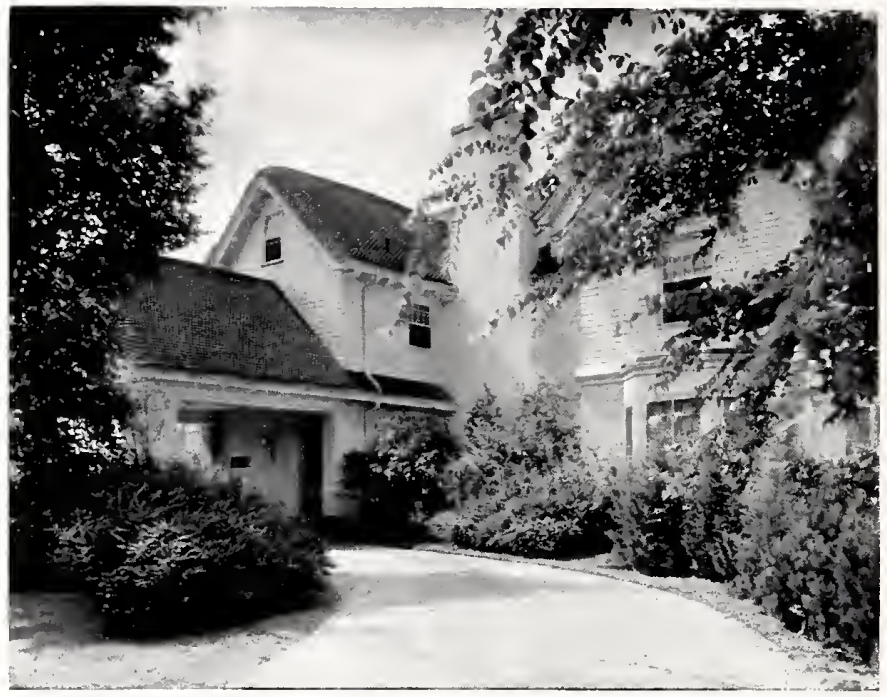

Let Hillenmcycr check your toundation planting to see if it is all that it should be. The foundation planting is one of the most important features of home planting. In this picture Barberry is planted to the left of the drive.

\section{Calycanthus-Allspice}

Calycauthus loridns (Svect sh rub or Allspiee). (F), 4 to 5 feet. Chocolate brown. This is an old-fashioned shrub well known to everyone. It blossoms intermittently all summer and its flowers are usually very sweet scented. Its reddish brown shoots and large, glossy green leaves are considered very attractive.

2 to 3 feet.......... .50 each

$11 / 2$ to 2 feet $\$ 1.75$ for $5 \ldots . \$ .40$ each

\section{Cercis-Redbud}

Cercis eanalensis (Medbud). Trained as a shrub. See page 21 for deseription.

4 to 5 feet.

$\$ 1.25$ each 3 to 4 feet.

$\$ 1.00$ each

Cereis chinensis (imponien) (Chinese Redbud). 10 to 12 feet. Listed by some as a tree but makes a bushy shrub of slower growth and larger. and darker flower than our native variety. Best in rather moist soil. Foliage extra good.

4 to 5 feet.......\$1.25 each; 3 to 4 feet

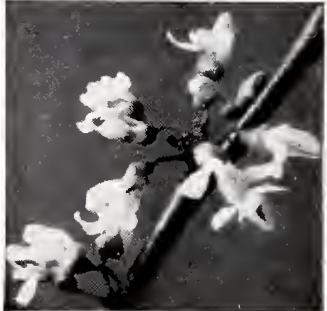

REDBUD
$\$ 1.00$ each

\section{Chionanthus - White Fringe}

Chiomanhus virminiea (White Fringe). 15 to $18 \mathrm{feet}$ An old favorite with white tassel-like flowers in May. Foliage, dark green. Slow growing.

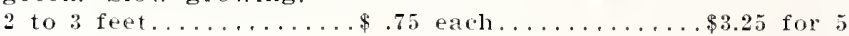

\section{Clethra-Sweet Pepper Bush}

Clethra aluifolia (Sweet Pepper Bush). Attractive summer blooming plant growing four to five feet, producing spikes of very fragrant white fowers in mid and late summer. Prefers semi-shade and moisture although it will grow in the open in good soil. Also called Summer sweet.

2 to 3 feet.....\$.50 each; 18 to 24 inches.....\$.40 each

\section{BARGAINS IN SHRUBS}

This year we have marked down our shrub prices to lowest in years. Our shrubs are cut back, well branched, stocky plants, wonderful root system and three to five years old. Don't confuse with department and dime store sizes and quality when comparing prices.

Flants fresh dug from the nursery are easily worth fifty per cent more than those not properly handled. We have the best shrubs in years. Then, too, we can give you any assorted list at quantity rates. Note special low prices. 


\section{Cornus-Dogwood}

Cornus Horida (White Flowerilla bocworod). 15 to 20 feet. White. May This is really a small tree and should be classed with shade trees. this and Fedbud are largely used. We hardy linow of a plant that is quite as attractive in all sensons of the year.

5 to 6 feet

$\begin{array}{llll}4 & \text { to } & 5 & \text { teet } \\ 3 & \text { to } & 4 & \text { feet }\end{array}$

\section{$\$ 2.00$ each}

$\$ 1.75$ each

$\$ 8.75$ for 5

Balled and Burlapped, 25 cents extra.

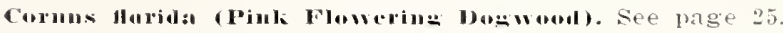

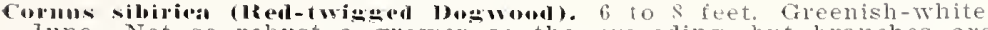
June. Not so robust a grower as the preceding, but branches are brighter red color in winter, making it even more attlactive at this creases its brilliancy of color when used in conspicuous places.

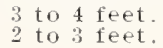$$
\$ .50 \text { each }
$$

$\$ 2.25 \mathrm{for} 5$

\section{Cotoneaster}

Cotoneaster tranelueti (1'ranchets Cotoneaster). A to $6 \mathrm{ft}$ A comparatively new shrub of silvery green leaves, long graceful drooping winter.

2 to 3 feet, Balled and Burlapped...\$1.50

\section{Crataeğus}

See page 26 .

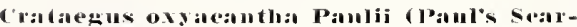
let Thoru).

Crataegus ongaeantha (English Hawthorn).

Crataenus eoldata (Washingtur 'Iluoru).

\section{Cydonia-Flowering Quince}

CMonia jalloming (billamese Qminee or Nowering Ruimer). 6 to $s$ feet. Scarlet. April-May. No doubt one of the most attractive spring blooming shrubs, blossoms alwars large, produced in great masses just as the leaves are coming out. Foliage is a dark glossy green. If it can be kept free of San Jose scale will pay for space it occupies in any planting.

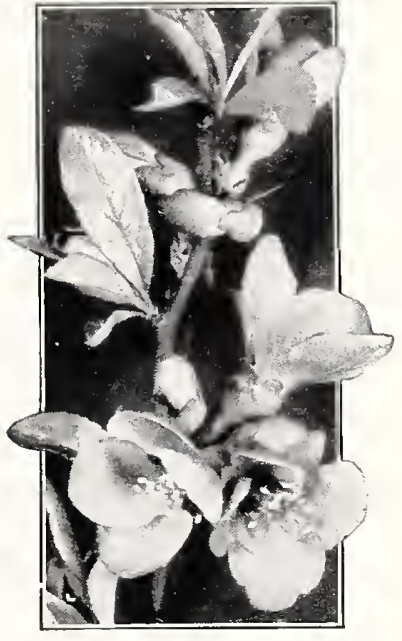

FLOWERING QUINCE.

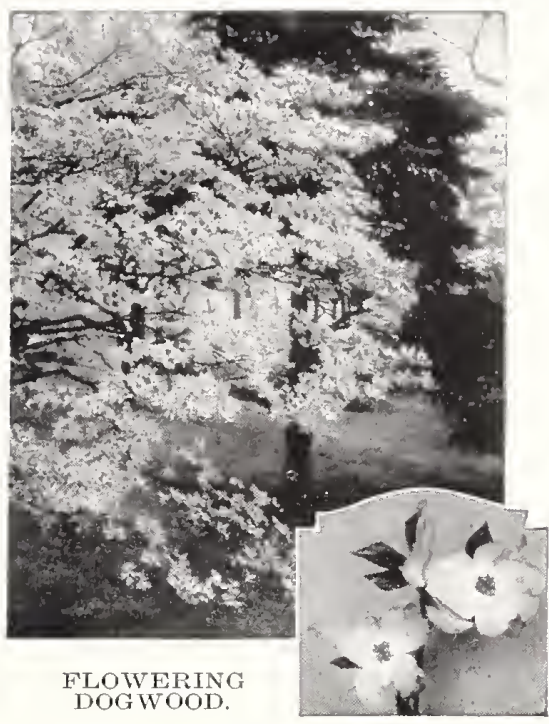

Deutzia

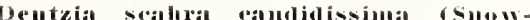
hake Dentria). 6 to 10 feet. White. June. A Japanese shrub noted for its haldiness, fine habit of growth and profusion of attractive flowers which are borne in racemes. The smatl flow erettes resemble double Lily of the Valley. Wherequick effect and screel is wanted this is a very desirable plant.

4 to 5 feet.

$$
\begin{aligned}
& \$ .75 \text { edeh } \\
& 3.25 \text { for } 5 \\
& \$ 2.25 \mathrm{fol}^{\circ} \\
& \text { * } 40 \text { each }
\end{aligned}
$$$$
\$ 1.75 \text { for } 5
$$

Delltwa gracilis (stender belltaia). (F). $1 \frac{1 / 2}{2}$ to $2 \frac{1 / 2}{2}$ feet. White. May. This is a dwart shrub very dense in growth, blooming piofusely in small latemes on alching branches. Sometimes tected places can be used as a low growing shrub for border planting.

2 to 3 feet. \$ .50 each. $\$ 2.25$ for $11 / 2$ to 2 feet.\$\$ 40 each.\$\$1.75 for 5

bentria sealura (Prideof therester). (F). 6 to 8 feet. Pinkish white. June. This valiety is very much the same as Teutzia candidissina, but is more populat on account of its color. It is rely hardy, adapting itself to any type of soil and if better known rould be one of the most satisfactory shrubs planted toray. 3 to 4 feet. 2 to $: 3$ feet.

$\$ .75$ each $\ldots \ldots \$ 3.25$ for 5
$\$ .50$ each $\ldots \ldots \$ 2.25$ for
$\$ .40$ each $\ldots \ldots \$ 1.75$ for

\section{Elaeaḡnus-Russian Olive}

1:1eagums anguxtifulia (kussian Olive). Grows 15 feet or more bark dark green but foliage silver in color. Fragrant, deep golden flowers followed by ornamental olive fruit. Very striking contrast among deep gieen foliage plants.

4 to 5 feet
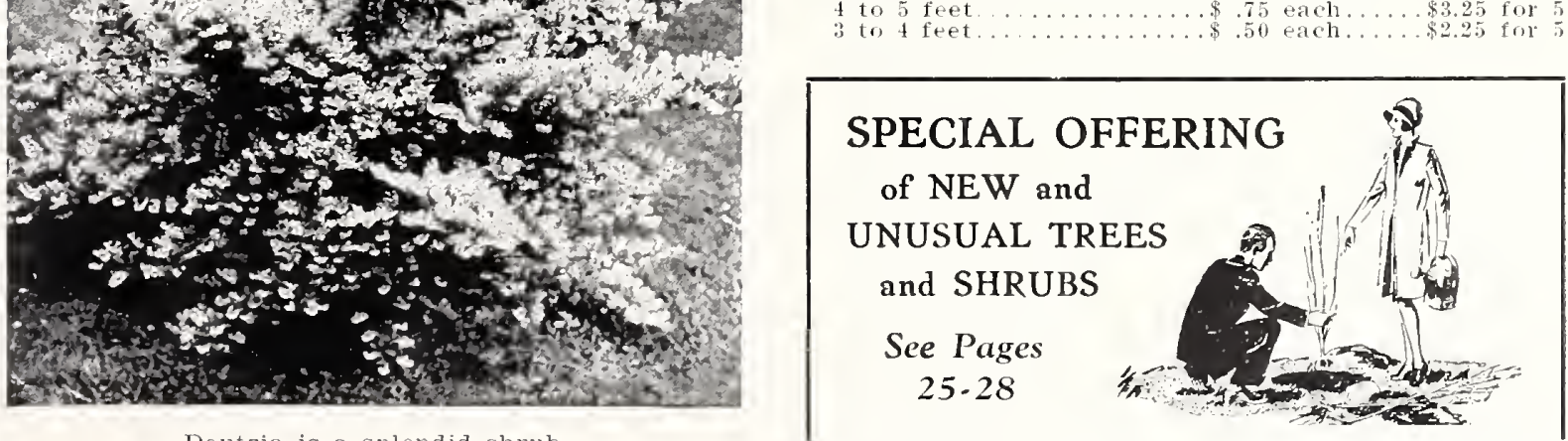

Deutzia is a splendid shrub.

Why wait years for shade when we can move in big trees for you, guaranteed to grow. 
Shrub Assortment Offer

\section{These prices apply to any assortment.} 5 of any +40 size for
5 of any \& 50 size for
of any 75 size for

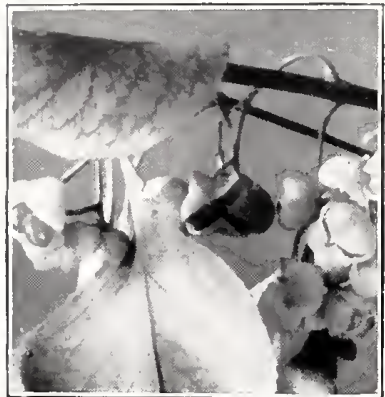

FRUITS OF EUONYMUS.

tions its mative liabitat is

3 to 4 feet...... 55 each; 2 to 3 feet..... .50 each

Guonymus europiens (Enropean Euonymus.) A tall slender shrub with green bark and deep green foliage coloring in the fall. Prized
coral fruit opening in the fall.

5 to 6 feet.. $\$ 1.00$ each; 4 to 5 feet.. $\$ .75$ each

Enowymus patens (Wveriston Wahoo). See page 19 for description.

$\begin{array}{llll}2 & \text { to } 3 & \text { feet, heary. B. \& } \\ 11 / 2 & \text { to } 2 \text { feet, heary, B. \& } \mathbf{B} .\end{array}$

\section{Exochorda-Pearl Bush}

Exochorda serandiflora (Pearl Busla). 8 to 10 feet. White. April. This is a plant that is not as well known as it should be. It is one of the most pleasing of the early spring flowers, being a mass of blossom during April. The leaves are light green of unusual construction and in mass planting should be used extensively. Plune severely at planting time for tensively. Plun
best results.

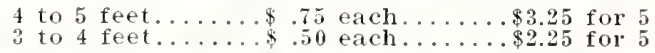

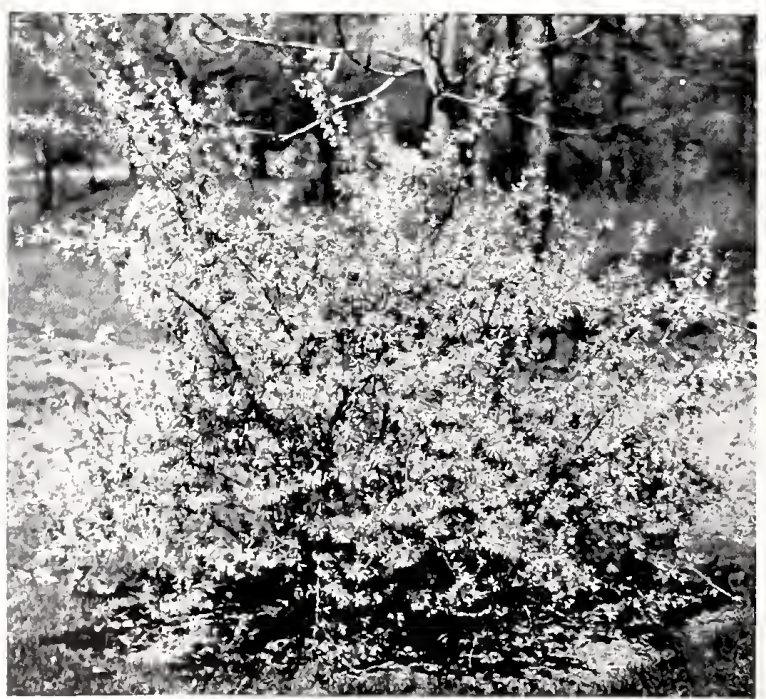

The Golden Bell is first to bloom in spring.

\section{Forsythia-Golden Bell}

Forsythia spectabilis (Showy Border Golden Bell). See pilge 26 .

Forsthia viridissima (Golden Bell). This is often called Green-stemmed Golden Bell. 6 to 8 feet. Yellow. April. This is decidedly the most popular of all the Golden Bells. The flowers appear before the leares and the plant malies a great show early in the spring. Priced below.

Forsy thia fortunei (Fortune's Golden Bell). 6 to 8 feet. Yellow. April. A folm of F. suspensa, but with more upright branches and darler, heavier foliage. Priced below.

Forsythia suspensa (Drooping Golden Bell). 4 to 6 feet. Yellow. April. A drooping variety that makes a desirable bush when planted alone or used on arch trellises.

4 to 5 feet.

to 4 feet

$\$ .75$ each

$\$ 3.25$ for 5

- to 3 feet.

40 each.

$\$ 1.25$ for

\section{Halesia-Silver Bell}

IIalesia tetrantera (Silver Bell) 15 to 18 feet. Blooming with the Dogwood, it is unusually attractive with its great mass of snow-white bell-shaped flowers. Small tree or large shrub. Foliage attractive.

5 to 6 feet.........\$ $\$ 1.00$ each ....\$4.50 for 5 \$ 50 each

\section{Hamamelis-Witch Hazel} IImamelis virginiana (Witel Hazel). 10 to 12 feet.
Ribbon-like, yellow flowers in late a utumn. Large tibon-1ike, yellow forge shady places.

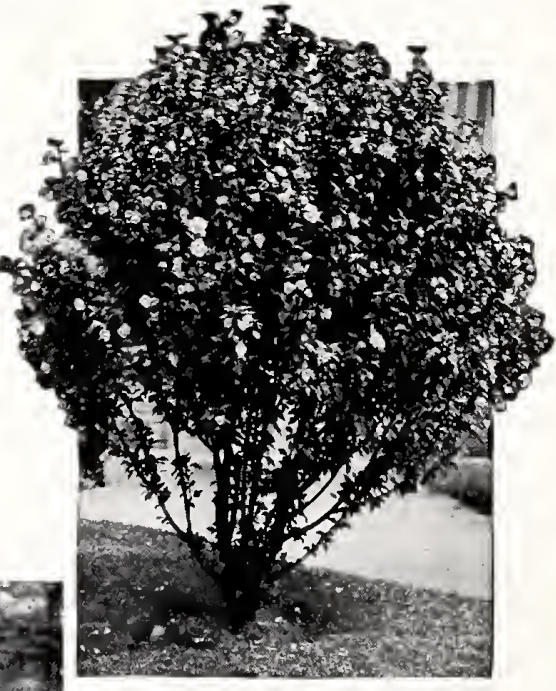

HIBISCUS, ROSE OF SHARON.
4 to 5 feet. $\$ .75$ eich 4 to 5 feet..\$ .75 each
3 to 4 feet..\$ .50 each

\section{Hibiscus- Rose of Sharon}

Hibiseus syriacus (Rose of Sharon). 10 to $12 \mathrm{ft}$. These prove one of the most satisfactory of shrubs because of their long period of bloom from June to frost. It is rather upright in growth, a nd rarely spreads over 3 feet. It does astonishingly well in cities or congested areas where other plants fail. Plant it with confidence. Listed to color:

' ot us A l b a, single white.

Joma a are, double white.

singl e Pi uk. Clear pink.

Ardens, double mottled pink.

Boule de Feu, double ed.

3 to 4 feet.......\$ .50 each ......\$2.25 for 5 2 to 3 feet.......\$ 40 each.......\$1.75 for 5

\section{Hydrangea}

lydraugea arboreseens grandiflora. (Snowhill), (F). 3 to 4 feet. White. May and June. (Also called Hills of Snow, Summer Hydrangea or Snowball Hydrangea.) $\mathrm{Th}$ is magnificent hardy American shrub is the very finest addition to this class of plants found in many a year. The blooms are of the very largest size, of pure smow-white color and the foliage is finely finished. One of its most valuable characteristics is its coming into bloom just after the passing of the early spring shrubs; while its long period of bloom from early June through August, makes it doubly valuable not only to the florist but to every owner of a garden. Perfectly hardy. Habit of plant excellent.

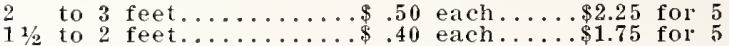
(Hydrangea Continued, Pase 9.) 


\section{Hydrangea-Continued}

Hydrangea panieniata graudiflora (Oh Fashioned Hydrangea). (F) 4 to 5 feet. White. August. Commonly known as Hardy Hydrangea. This popular variety does not bloom until Augus and September. The large spilies are first greenish-white, then pure white, latel changing to bronze pink. The blossoms al' a bronze pink and taken indoors they will dry and make a very attractive winter bouguet.

2 to 3 feet.

$$
\$ .50 \text { each } \ldots \ldots \$ 2.25 \text { for } 5
$$

\section{Hypericum-Gold Flower}

Hyperioum moserianum (St. John's Wort or Gold Flower). (F), 1 to 2 feet. Yellow. July to September. This rather unique low growing shrub always attracts attention. Flower a beautifu rich yellow, borne on slender stems, surrounded with rather roundish, leathery green leaves throughout the summer. During
severe winters it often kills to the ground but next spring will come back more vigorous than before.

$1 \frac{1}{2}$ to 2 feet

1 to $11 / 2$ feet

$\$ .50$ each

40 each

$\$ 2.25$ for 5

Jasminum - Winter Jasmine

Jasminum mudiforum (Winter Jasmine). 2 to 3 feet. Rich, golden, yellow flowers appearing before foliage in March and April. stems green and leaves small and glossy. Creeping in habit of growth.

2 to 3 feet.

\section{Kerria}

Kerria japouica (single Japanese Fer ria). Grows 4 to 5 feet with yellow blossoms blooming in May and intermittently throughout the summer. Stools from the ground and its green branches malke interesting winter effect. See prices below.

Kerria ìmoniea dorepleno (Double Kerria). This grows 4 to 6 feet, having bright green stems and attractive deep green foliage. The blossoms are double, being globe shape and unusually attractive. Blooms all summer. 2 to 3 ieet....\$.50 each ...\$\$2.25 for 5

Kōlkwitais) (Heauty Hush). See page 27 .

\section{Lagerstroemia-Crapem yrtle}

Cagerstroemia indiea (Crapemyrtle). Familiar to everyone living in the South. It has small, very dark green shining leaves, and blossoms in August and september in panicles of peculiar but attractive flowers. Not hardy in many places in Kentucky. Plant ouly iu spring. Your ehoice: Pink, Hed or Purple.

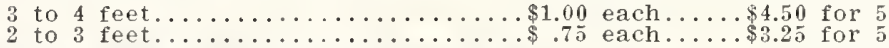

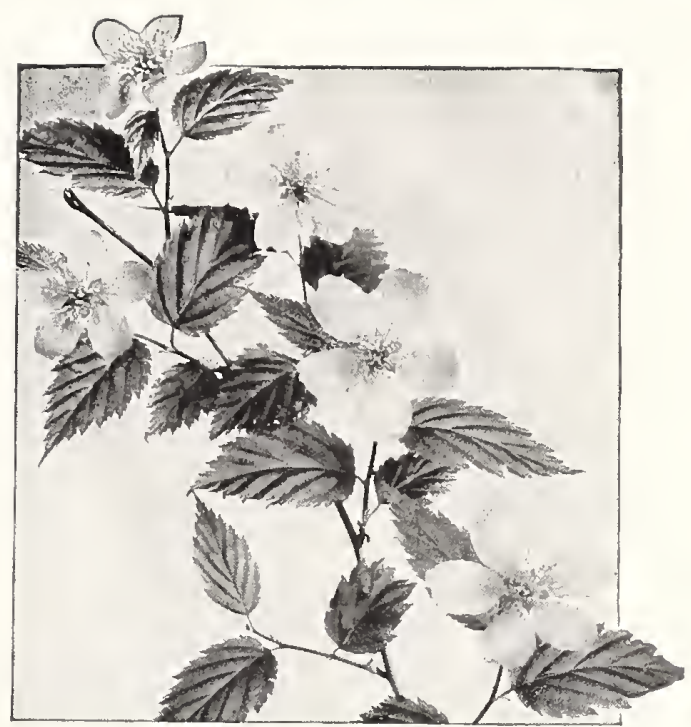

ISERRIA JAPONTCA-KERFIA

\section{Lespedeza-Purple Bush Clover}

Lespedera (Purple Hush clover). One of the most attractive. August blooming herbaceous shrubs. Simply covered with reddish purple, sweet scented, pea-like flowers, borne on arching branches and lasting several weeks., Very glaceful, makes a cron "forvard" plant for shrub freeze uut in severe winter, but come back each spring.

Strolug plants, 2 yr.......... 50 each

$$
\$ 2.25 \text { foi }
$$

\section{Ligustrum-Privet}

Liguxirum simense (Amoor Privet). (F), 6 to 10 feet. White. June. A small leaved almost evergreen variety of Privet that is much used for hedges but also very desirable for landscape work because of its unusual rapidity of growth, good foliage and graceful branching. It is not particular about soil and for semicelled. It is not used enough as a shrub. We are very partial to its use in the South. Hardy where California Privet vill succeed. See prices below.

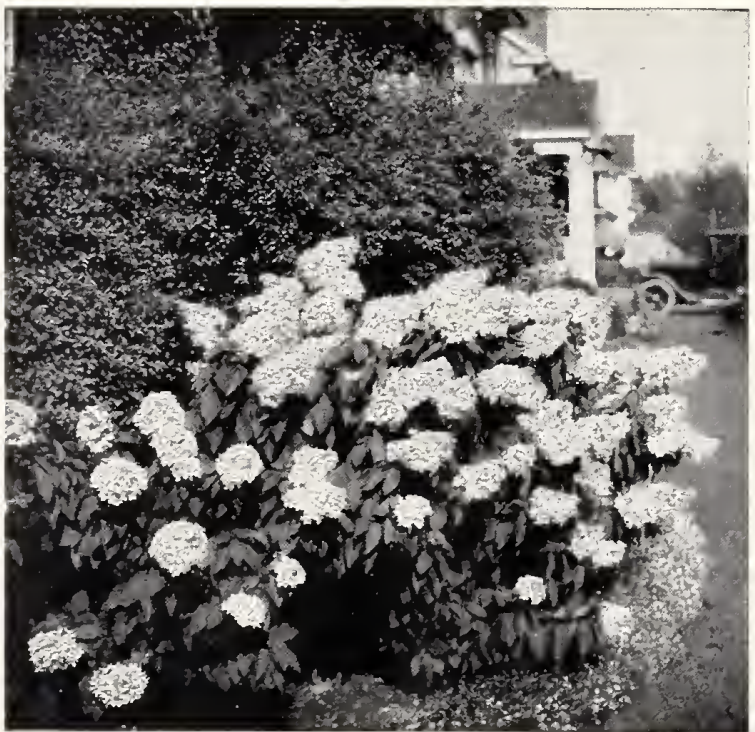

Hydrangea P. G. is ideal for foundation planting.
Lignstrum ibota (Privet lbota). 6 to 10 feet, This is another of the Chinese type resembling Regel's Privet very closely but being more erect in growth. Its bronze foliage in the fall and attractive berry make it valuable. Then, too, its hardiness and ability to withstand not only severe weather, but adverse veather plants for mass plantin.

Lisustrum ibotum remeli:uum (Privet Regels). (F) 5 to 7 feet. White. June. A low, spreading variety, being very twiggy, with a dense foliage not so glossy as California. Because of its graceful appearance, haldiness and adaptability to any soil and shady places, it is the most widely used Privet for land scape work.

4 to 5 feet.

to 4 feet.

0 , 1 eet.

\section{Privet for Hedg̨es}

(See Hedge Plants, page 32.)

Plant a hedge of privet or some other desirable hedge plant. There is no type of planting more useful or moie ornamental than a hedge. Turn to page 32 for description of hedge plants and suggestions on planting and pruning the hedge.

The new Beauty Bush described on page 27 is a wonderful shrub and quite beautiful. 


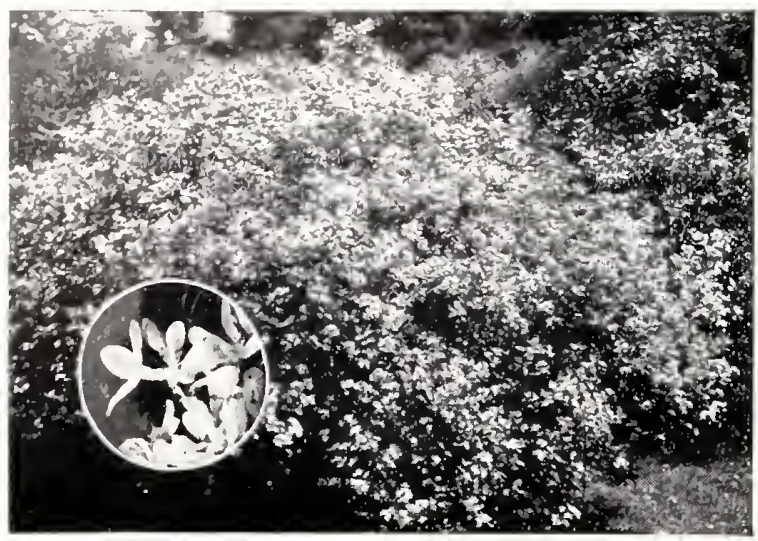

LONICERA-BUSH HONEYSUCKLE.

\section{Lonicera-Honeysuckle}

Lonicera fracrantissima (Fragrant Busll). (F). 7 to 10 feet. White. April. So called because of its very fragrant blossom. The foliage is very deep green and glossy. This grows well in partial shade, in adand glossy. This glows well in partial shade, in adBerause of its nearly evergreen habit it is being largely used for hedges. Without doubt one of the largely used for hedges. Without doubt one of the
very best plants for landscape purposes grown very best plants for
today. Prices below.

Lonicera morrowi (Morrow's Honeysnekle). 8 to 12 feet. This is one of the best, quick growing, compact and "filler" shlubs "e have, The foliage is bright gleen, the blossoms cream colored appearing in Aplif. The red and coral fruits follow from June to August. In dry or moist soil, shade or sun, eity
or country, this variety vill thrive. Prices below.

Lonicera standishii (Standish loneysmekle). 4 to 5 feet. Creamy white blossoms in March or early April before fol:age aplears. The leaves are very deep green and persist nearly all winter. The beries
are red. 'This is one of the best low-glowing honeysuckles. See prices below.

laniecrat tatarica (Tatarian 11omessuckle). 7 to $9 \mathrm{feet}$ Pink. April. This is very attractive in blossom. pink. April, This is very attactive in blossom. being one of the few early pik fowering shrut
Has bright led beries that stay on all summer.
4 to 5 feet
.75 each
to 4 feet
.50 each
$\$ 3.25$ for 5
2 to 3 feet.

Mag̀nolia

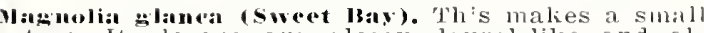
tree. Its leaves are glossy, laurel-like and almost evergreen. The flowers are white in June and ale followed by attractive fruits.

3 to 4 feet, Falled and Burlapped.

sing

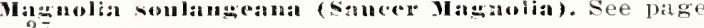

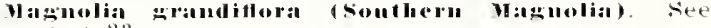
lage 23.

\section{Mahonia}

Malnonia aequifolinm. This is a broad-leared evcrgleen shrub. For description see page $1 !$.

\section{Malus-Flowering Crabs}

Walus floribundal (Japanesc Floweriug Crab), 12 to 15 feet. Makes a small tree with graceful arch ing blanches. When laden with led blossoms and buds, shading to pink, it is a sight to beh
the spling it is celtainly a mass of color.

4 to 5 feet.

$\$ 1.50$

lolus inensis pleat (Bechtel's Crab). See page 26.

Malus seheidectieri (Selreidecker Crab). 10 to 15 feet. Very similar to the above variety, Floribunda. Has larger, double flower's

4 to 5 feet

$\$ 1.50$ each

\section{Oxydendron-Sour Wood}

Mvendrou arboreum (Sour Wood). 10 to 12 feet. White, July and Ausust. Flowers resemble Lilyof-the-Talley, but are borne in panicles. Its foliage is most brilliant in fall.

3 to 4 feet. $\$ \begin{array}{r}75 \text { each } \ldots \ldots \$ 3.25 \text { for } 5 \\ .50 \text { each } \ldots \ldots 2.25 \text { for } 5\end{array}$

\section{Philadelphus-Mock Orangెe}

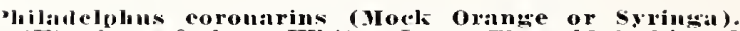
(F). 6 to 8 feet. White. June. The old-fashioned mock orange, well known to everyone because of its waxy white, fragrant flowers. It proves a specially good plant for every use, the foliage being large, oval in shape and deep green. For cut flowers it is valuable, and pruning in this manner often keeps the bush confined where it is not desirable to have it grow too tall. Very valuable for background, or grouping.

4 to 5 feet

3 to 4 feet

$\$ .75$ each $\ldots \ldots \$ 3.25$ for 5

2 to 3 feet

Philadelphus coromarins aureus (Golden Leaf Mock oriuge). 3 to 4 feet. Has dwarf, compact habit with bright, golden leaves that are most attractive. The blossoms are white. They are very good for a low border shrub.

2 to 3 feet

$\$ .50$ each

$\$ 2.25$ for $^{\circ}$

Plibadelphns grandiflora (Large-flowering Mock Oramge). 7 to 10 feet. White. June. This is the most vigorous but lacks somewhat in fragrance. Blossoms are larger and very attractive. Where a tall plant is wanted there is hardly anything better than this. Succeeds under all soil conditions.

4 to 5 feet..........\$.75 each....\$3.25 for 5 3 to 4 feet............ 50 each ....\$\$2.25 for 5

Pluildelphns lemoinci (Lemoine's Mock orange). This grows 4 to 5 feet and is of good, compact, upright habit. Leaves smaller than the other varieties and blooms sweetly scented. Where a Mock Orange is wanted for foundation or other low planting this variety is recommended.

3 to 4 feet....\$.50 each; 2 to 3 feet....\$.40 each

I’hiladelphus virwinal (Mock Oriüe). See page 27

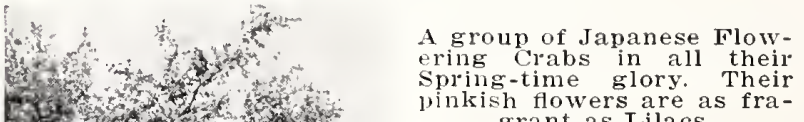
grant as Lilacs. 
Physocarpus-Ninebark

Plusocarpus opulifolins (Ninebark spirea). S to 10 feet. A vigorous shrub doing especially well in shade, with creamy white flowers in May and June. Pods assume a bright red color and are most attractive on the long arching branches.

4 to 5 feet.........\$ .50 each; 3 to 4 feet........\$ $\$ 40$ each

\section{Prunus-Plum}

Prumus chlabra albiplena (Double Flowering Nlmond. (F). 3 to 4 feet. Rose-pink. Apric with double pink flovers of medium size from base to tip of branch. The plants are usually propagated on plum or peach stock as it belongs to this family and should be planted deeper than ordinarily advised for other shrubs.

2 to 3 feet................... $\$ 75$ each....\$3.25 for 5 1 to 2 feet

$\$ 3.25$ for 5

Prunus pissardi (Purple Plum). We have a new variety of this called Cistina, and valued chiefly because of its purple foliage in the spring. This variety is a deeper shade than the ordinary courage new growth for best color effect.

3 to 4 feet.

Prunus trilobat plena (Double Fowering Plum). Grows 6 to 8 feet. Has deep pink flowers in April and called one of the most attractive of the spring flowering trees.

4 to 5 feet........\$1.00 each; 3 to 4 feet........\$. 75 each

\section{Pyracantha}

Pyracatha. (See Broad-Leaved Evergreens, page 19.)

\section{Rhodotypos}

Hhodotypos kerrioides (Jetbead). (F). 4 to 5 feet. White. May and June. Very ornamental shrub with brigh green, plaited leaves and large white flowers one-half to one inch across. These are produced at the end of the branchlets and are followed by conspicuous shining black fruits that adhere practically all winter. A desirable shrub.

4 to 5 feet...... \$ $\$ 75$ each $\ldots \ldots 3.25$ for 5

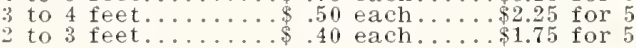

\section{Rhus-Sumac}

Hthus aromatiea canadensis (Fraprant sumae). A to 5 feet. Yellow flowers in clusters followed in summer with coral red fruits. Has pleasor in dry, shady, rocky places.

2 feet.....\$.50 each; $1 \frac{1 / 2}{2}$ feet.....\$.40 each

IRhus eopallina (Shining Sumate). 7 to 10 feet. The native variety that colors so wonderfully in the fall. It is not as robust a grower as some of the others but because of its glossy is most desirable.

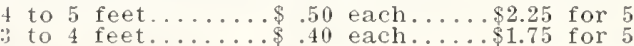

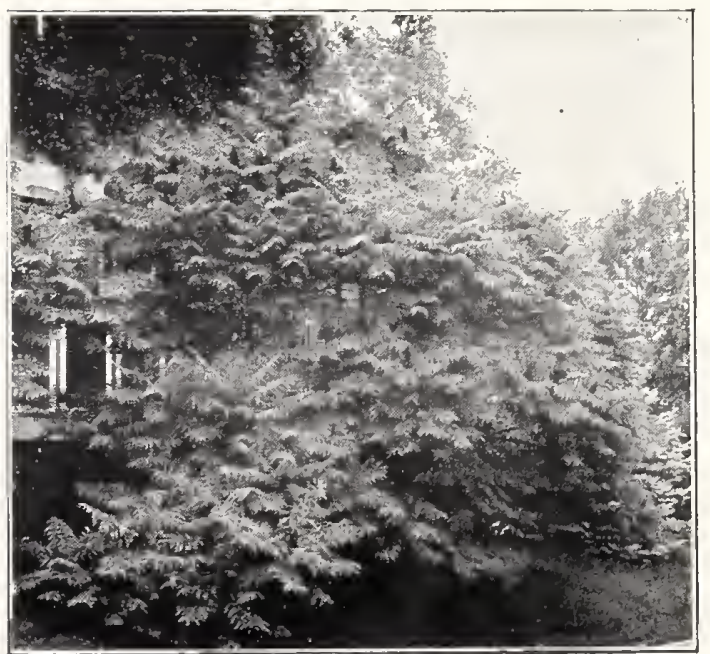

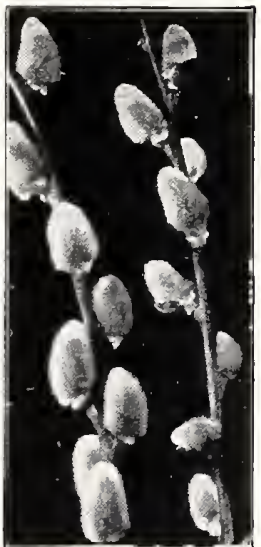

PUSSY age lesembles our native locust but the of long, graceful, deep rose pink colored flowers summer but not hearily.

$\begin{array}{lll}4 & \text { to } & 5 \text { feet } \\ 3 & \text { to } & + \text { feet }\end{array}$

2 to 3 feet

.50
.40 each

$\$ 3.25$ for 5

$\$ 1.75$ for 5

Rosa-Rose see pages 29-31.

Salix - Willow

sulix capreal (Pussy Willow). 15 to 20 feet. These are bush form and may be classified as sinall trees. 'They grow on catlins that appear before the foliage in the spring. Valuable because winter-cut spikes may be forced indoors. 4 to 5 feet.

\section{Sambucus-Elder}

Sanbuens anadensis anrea (Golden Elder). 7 to 9 tetet. This golden leaf variety is very attractive and where color is wanted in a tall shrub this is recommended. Has the usual types of soil.

3 to 4 feet

2 to 3 feet.

\section{SEE SPECIAL BARGAIN PRICES OF SHIUB} ASSORTMENTS ON NEXT PAGE.

SHREDDED SUMAC-(Rhus Typhina Laciniata).

Shrubs with evergreen foliage are needed in your border. Turn to page 19. 
Spiraea-Spirea

Spiraea Inthony waterer. (F) 2 feet. Bright pink. June and July. A compact low-growing s h $\mathrm{r}$ u with dense foliage usually deep green with occasional variegated leaves of pink and white on young growth. Flowers are borne in full flat clusters on erect stems. If these are cut away when they intermittently during the summer. Ver valuable for edging in front of shrubbery or sometimes used as a dwarf hedge.

$1 \mathrm{1} / 2$ to $2 \mathrm{ft} \ldots \$ .50$ each . .\$2.25 for 5 1 to $1^{1} \mathrm{ft} . . \$ 40$ each. .\$1.75 for 5

Spiraea arouta (Garband spirea). to 5 feet. This has small, light gleen leaves and is very free flowering in Aplil. Its soft foliage gives it a billowy appearance and makes it one of the most attractive plants. Very much like Spirea ly larger.

2 to $3 \mathrm{ft} \ldots \ldots \$ .50$ each.$\$ 2.25 \mathrm{fol} 5$ 11.2 to $2 \mathrm{ft} . . \$ 40$ each. $\$ 1.75 \mathrm{for} 5$

Spiratea doumlasi. 6 to 8 feet. Deep pink. July. Slightly taller and a little mole branched than spirea Billiardi. Telminals of each branch
clowned with flower spilie six inches long.

3 to $4 \mathrm{ft} \ldots . \$ 50$ tach ...\$2.25 for 5 2 to $3 \mathrm{ft} \ldots . \$ .40$ each ...\$1.75 for 5

spiraca fortumei. 4 to 5 feet. This variety is taller than spirea Anthony waterer, but is not as vigorous as spirea Douglasi. The color of its blossoms is pink and they bloom in June and July. The terminal growth has a reddish appearance which is quite pleasing.

3 to 4 feet....\$.50 each; 2 to 3 feet..... 40 each

Spiraea prunifolia (Plum-leaved Spirea). (F). 5 to 6 feet. White. April-May. This is an old-fashioned variety, flowers borne. close to the slender erect branches in the spring before foliage appears. The indivldual flowers resemble miniature roses and are usually borne in great profusion. The foliage is shiny dark green and in the fall turns bright red.

3 to 4 feet.........\$.50 each....\$2.25 for 5 2 to 3 feet..........\$.40 each....\$1.75 for 5

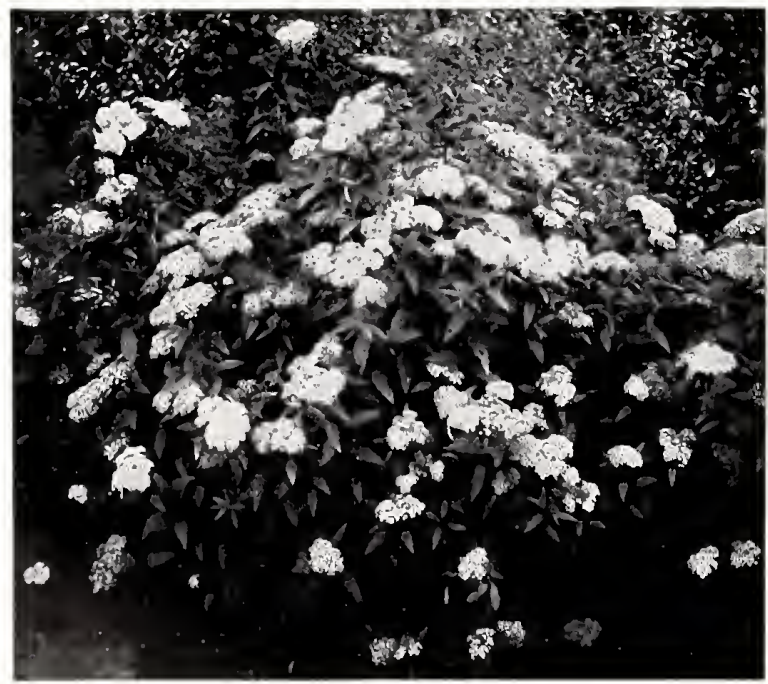

SPIREA ANTHONY WATERER spiraea reevesiana (Reeves Spirea). (F). 4 to 5 feet. White. May. This is one of the best of the Spirea group. White flowers borne along the stem just as the foliage appears make a most attractive bush wherever used. The foliage appears early and remains exceptionally late in the fall. In habit it is very graceful and can be used in foundations where can be used this height ale desired.

3 to 4 feet. $32.25 \% 5 \% \$ 50$ each

2 to 3 feet ......... 40 each $\$ 1.75$ for 5

Spiraea thumberri (Snow Garland).

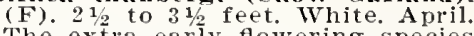
The extra early flowering species is the pride of the Southland. It is spreading in growth with arching slender branches that ale a perfect mass or minute fowers followed with exceptionally delicate green foliage. For edging purlecommend it highly. 2 to 3 feet.......... .50 each $11 / 2$ to 2 feet........\$ 40 each $\$ 1.75$ for $5 \cdots \$ .40$ each

Spiraea trichoearpa (līorean Spirea). See page 28

Spiraea vanhoutte (Bridal Bower or Hridal Wreath). (F) 4 to 6 feet. White. May. This is the most useful of the hardy shrubs. It has grown so popular that we sell more of it than any other variety we grow. The flowers are in flat clusters usually an inch or more across produced on spreading, pendulent branches often drooping to the ground. In full bloom they are the ground. In full bloom they are a mass of white and never fail to an attractive green which it rean attractive green which it retains late in the year. This valiety hedging, grouping and mass effect. There is nothing superior in the catalog.
plant Spirea Vanhoutte.

4 to 5 feet..........\$ .75 each....\$3.25 for 5 3 to 4 feet $\ldots \ldots \ldots \ldots \ldots \ldots \$ .50$ each $\ldots \ldots \ldots 2.25$ for 5

\section{Symphoricarpos-Snowberry}

S y u hor ica r pos racentosus (Sllowberry). (F). 4 to 5 feet. This shrub has small pinkish flowers in July, followed by white berries which remain on well into the winter. Very attractive medi $\mathrm{m}$ growing shrubs. Prices below.

Symphorjearpos vulgaris (Coralberry. 4 to 5 feet June. This is a native shrub that in many localities grows in great masses. It is very hardy and easy to establish where other things fail. Its beauty lies in the wonderful wealth of coral berries that come in late summer and usually adhere all

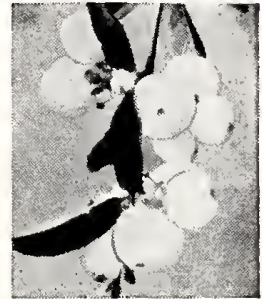

SNOWBERRY.

3 to 4 feet ...... \$ $\$ 50$ each... $\$ 2.25$ for

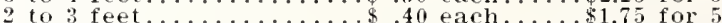

\section{Shrub Assortment Offer}

Make up you own collections while these low prices prevail. Remember that even though
these are bargain prices you get the same quality for which Hillenmeyers are famous.

These prices apply to any assortment.

5 of any $\$ .40$ size for............. $\$ 1.75$

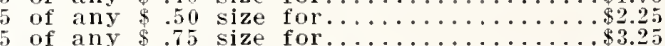

CONSIL'T OUL IANDSCAPE DEPARTMLNT

New and unusual shrubs and trees are offered on pages 25-28. 


\section{Syringa-Lilac}

syrimza josikaca (Hungariau Lilac). Another new addition to our list, growing $s$ to 10 feet with heavy round-like foliage. It produces violet Howers later than the ordinary lilacs and the foliage is not sub-
ject to mildew, remaining dark green all summer. to 4 feet.

Syrusa persica (Persian Libae). 8 to 10 feet. This has a rich, liac color and blooms slightly later than the

3 to 4 feet.

Sy xiuna villosa (Late Tilse)، This is the latest blooming variety having pale pinkish lilac blooms that are very fragrant. Plants grow 6 to 8 feet, making bushy compact specimens.

3 to 4 feet.

Syringa vulparis alna (Common White Lilae). 6 to 8 feet. April. No shrubs are better known than the Lilac. This is the old fashioned white that everyone knows. Prices below.

Syringa vulgaris (Common Purple Lilae). 7 to 10 feet This is the old fashioned variety always so familiar in our grandmother's garden. Usually more vigorous in growth than the white variety.

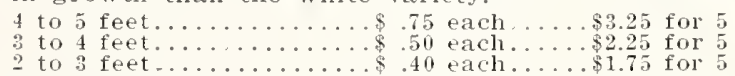

French Lilae. These are the very much improved variety sold to name and color. They bloom unusually soon after planting and their large trusses of blossoms are very attractive. They ale mole expensive than the common variety but

Chas. $\mathbf{x}$. Reddish purple.

Mme. Lemoine. Double white.

Viehael bneluer. Pale Lilac.

Pres. Grev. Blue.

Wil. Robiuson. Deep pink.

to 4 feet.

$\$ 1,00$ each .....\$4.50 for 5

\section{Tamarix}

'Tamarix pentaulra. Often known as: 'Tamarix aestavalis (Five-xtamen Tamarix). (F). 6 to 7 feet. Pink. June. Shrubs with strong but slender, delicate growth. Filmy, blue grey foliage similar to asparagus with carmen pink flowers in June, and scattered blossoms the balance of the summer, making it an
unusually desirable shrub. Will grow in poor and unusually desirable sh
dry soil. Prices below.

Tanarix afrieana (Afriean Tamarix). 7 to 10 feet. Lavender-pink. April. This is the most vigorous of the Tamarix family. It has strong canes that bend gracefully as they leng the on the stems before the foliage and ale pleasing in mass planting. Sea green foliage and drooping liabplanting in shrub borders.

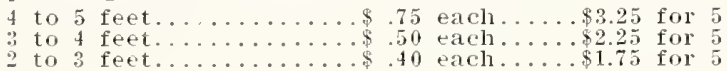

\section{Viburnum}

Viburumm acerifolinm (Maple-Leaved Jibnrunm). A slender shrub growing 4 to 6 feet with leaves that lesemble the Maple tree. The fow This is followed flat heads in May, white in color. This is followed for planting in the shade although it does well in for planting

4 to 5 feet....\$ .75 each; 3 to 4 feet....\$ .50 each

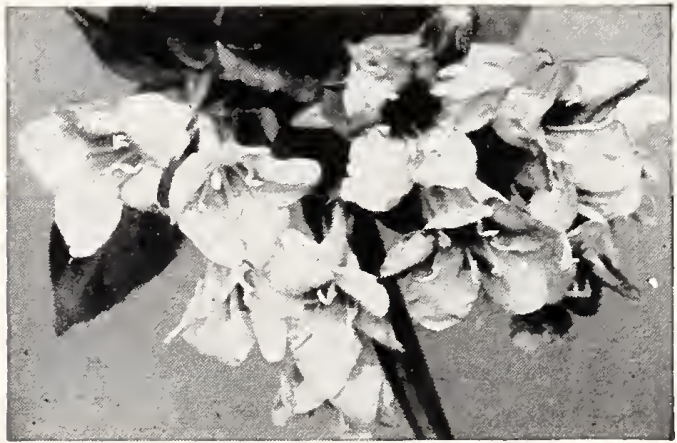

WEIGELA ROSEA.

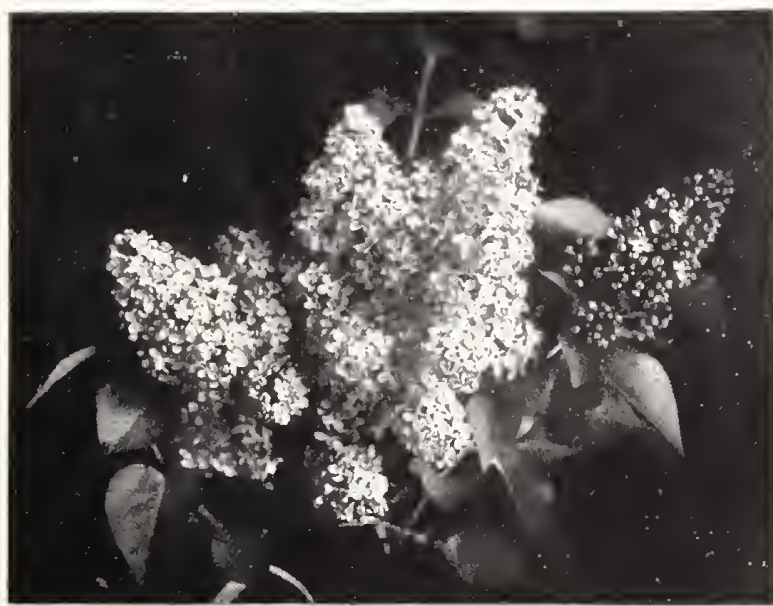

PUPPLE IILAC-An old favorite.

Viburunm dentatum (Arrow Wrod). 10 to 12 feet. Flowers creamy white in flat clusters in Mlay and the foliage coloring is purple and red in the fall. This will grow in wet soll. See prices below.

Viburnum lantana (Wayfaring 'lree). (F). 10 to 12 feet. White. June. A large, vigorous shrub with soft, heavy lantana-like leaves and large clusters of white flowers in May, succeeded by red berries
which turn black as they ripen. See prices below. Viburumm opulus (Himbush Cramberry). 8 to 10 feet.
White. May. This plant belongs to the Snowball family and is unusually attractive because of its bright berries that attract bilds in midsummer and also for its color effect in the fall. The flowers are also for its color effect in the fall. The flowers are inconspiculous. This is one of the best things for natural planting but owing to scarcity of stock it

Imericau Hizhlush Cranbery. See page 28

Viburnum opulus sterile (Common Suowball Busli). 10 to 12 feet. White. May. This old fashioned variety is well known to every lover of plants. Its balls of pure white literally cover the bush when in bloom. See prices below.

Vibnrum tomentosmu blieatum (Japanese Suowhall). (F). 6 to 8 feet. White. Mlay. This species is one of the most satisfactory shrubs grown. Its pure white double blossoms with a setting of dark plaited leaves and perfect form lnake it one of the best. Fine for

3 to 4 feet

$\$, 75$ each

$\$ 2.25$ for 5

Viburumm rlytiophyllum. See listing in Broad-Leaved Evergreen section, page 19.

\section{Weigela}

Weimela eandida (White or snow Weimela). (F). 5 to 6 feet. White. May. Most vigorous of the Weigela variety. Flowers are large and quite showy. In exposed places the tops are sometimes injured in severe winters. Very rapid in growth and seems to
thrive better in light soil. See prices below.

Weimela desboise. This is a new addition to our list, being a deep rose pink, growing 6 to 7 feet in helght and blooms profusely. Sereral shades darker than Weigela rosea.

Wrimela fhribuma. Stronger growing than. We $\mathrm{g}$ e l a Eva Rathke. Blossoms of bright crimson, blooming in June. Consideled the best of the led shades.

i to 4 feet........\$.50 each: g to : feet.......\$.40 each

Weichela rosea. (F). 4 to 5 feet. Pink. May. The most popular Weigela sold today. Its delicate pink, bell-shaped blossoms are borne in great profusion along great, arching canes. 'There is also a scattering of blossoms throughout the summer. The leaves are large and especially free of disease. This variety is the best of the group and is good for all uses where a shrub this height is needed.

3 to 4 feet. .50 each
$\$ .40$ each. $\$ 2.25$ for 5

You will get better results with Hillenmeyer stock delivered fresh direct from the nursery. 


\section{EVERGREENS-Rich in Color -}

\section{Our Evergreens are noted for shapeliness and beauty}

T $T$ IS impossible to describe here the beauty and utility of the aristocratic Evergreens. They have an individua charm that they retain throughout the entire year. Their green foliage of every possible shade and hue is especially pleasing during the winter months, when everything else is bleak and dreary. The many different types and forms make it possible to secure varieties appropriate for any planting.

Evergreens are not all alike. Do not confuse the plants listed here with the seedling stock offered by some nurseries. The better varieties and dwarf plants are more expensive, because it takes a great amount of time and care to grow them. It is possible to buy Foundation and Doorway Collections at low prices, but these trees grow rapidly and may not prove entirely satisfactory after a few years.

Plant permanently and, if necessary. do it by sections. Then the complete planting will possess a grandeur that cannot be excelled.

\section{EVERGREEN PRICES}

We have cut deeply into prices on al evergreens. 'They are lower than they have been for many years. Look at our prices on Arbol Vitaes, for instance, and
be convinced. Do not compare prices alone. Height does not indicate quality. ive shear our evergreens constantly and they ale full. busly and better balanced thati most plants offered. Vis iting nurserymen have said we have the finest lot of evergleens in Ameriea. Mavle this is liberal but we da know they are extra good Quantity lot speciahly pricod

\section{Arbor Vitae-Thuja}

Thuia Occidentalis (American Arbor Vina. One of the most popular evergreens be cause of its easmess to transplant, glow ing kindy under adverse conditions and a a specimen or hedge plant it is very attrac of growth and while it is not as green in of growth and while it is not as green in other varieties it is one of the most popular because of its many good qualities. 6 feet .................. \$5.00 each 5 to 6 teet 31 to 5 feet $\$ 4.50$ each to $31 / 2$ f teet \$2.50 each $\$ 2.00$ erch

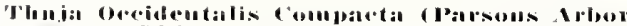
Bivate. This variety is almost globe shape, simila to Globe Ailoor "vitae in practically "very respect, but slightly bighter groen. Very good for formal planting. $21 / 2 \times 21 / 2$ fetet j to $21 / 2$ feet +4.50 a ach 1 to $1 \frac{1}{2}$ feel

Whuja Oereidentalis Ellwangeriana cTom Glumb lrbor Viral. This has very fine cut " This is characterize the othe ind has a soft ftather compact growing found in other evelogens. nlo

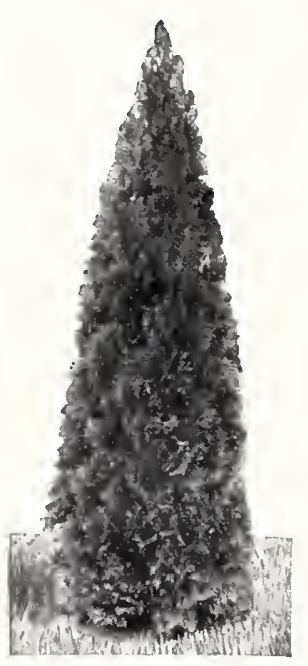

Thuja Oecidentalis Fillicoides (Femleaf Arbor Vitat. A decided pyramidal tree not unlike the regular Pyramidal Arbor Vitae, except that the foliage is a deeper green and has a "crinkled" appearance. Slow growing and very attractive.

tho to 5 feet.

$\$ 5.00$ each

Thuia Oecidentalis Giobosa (Globe Arbor Vitac). 'This usually develops into a perfect globe shape plant. the spread equaling the lieight. The foliage is light green and nttlactive. These are largely used for front line planting, as specimens in urns or symmetry is especially desired.

$21 / 2 \times 21 / 2$ feet........... $\$ 4.50$ each 2 to $21 / 2$ feet............. \$3.50 each

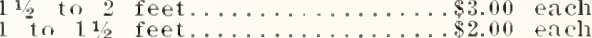

I'huja Oreibleulalis Lurear (Geo. Peabous Arbor. Virac). This variety is similar to the American Albor Vitae, except that the foliage is golden when exposed to the direct l'ays of the sun. It is by far the best of the American Golden types.

$21 / 2$ to 3 feet............ \$3.50 *ach PYPAMIDAL
APBOR YITAL

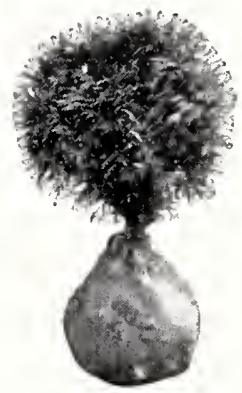

Thuia Orevidentalis Pyramilalis (Pyramidal Arbor Vitac). This is strilingly attractive, spleading very little at its base and retaining the shape without shearing. The color is deep rich green and like all Arbor Vitaes is easy to transplant. Fol corners. in front of pillars, center or backglound of group plantings there is hardy an erergreen of the dwarf rniety that is quite so popular.

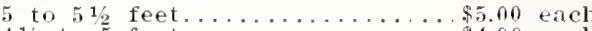
$41 / 2$ to 5 feet.............. $\$ 4.00$ each

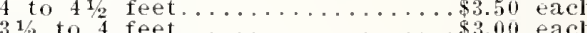

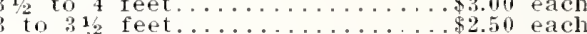

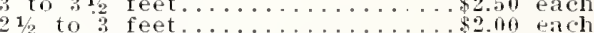

Whuja Oecildentalis leosentlatis (Roscuthal Arlor vitae). Much like Pyramidal Arbor Vitae, being dark green, broader at the base ind very slow in growth.

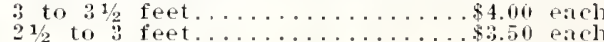

ARDOR YT A I

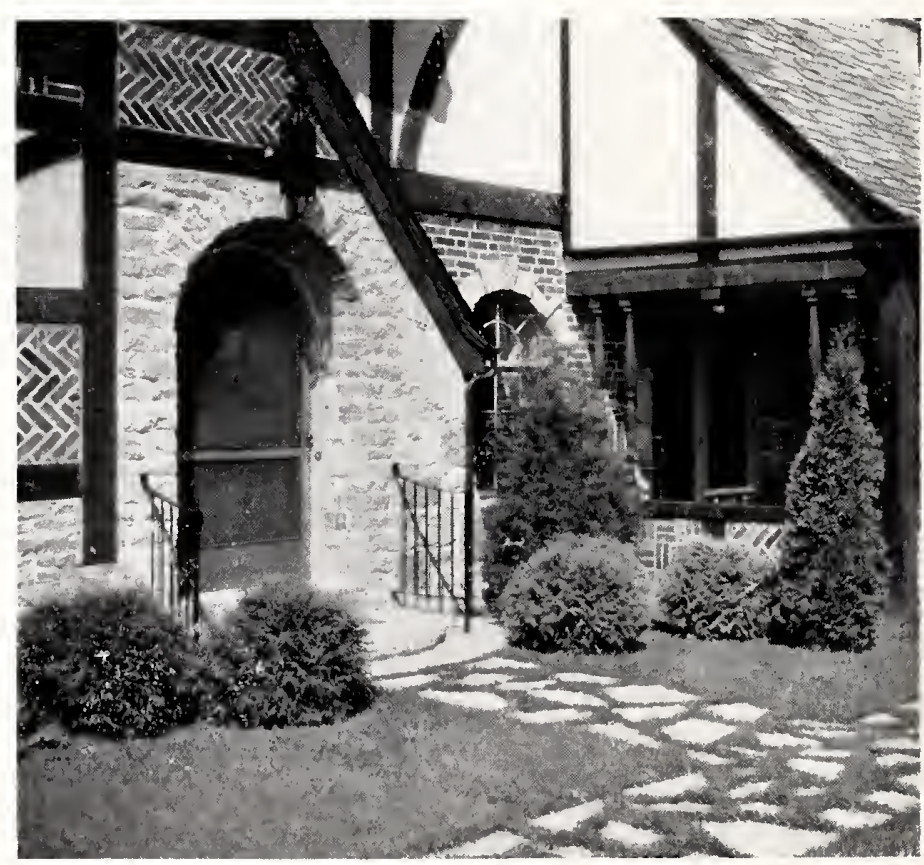

An attractive entrance planting of Arbor Vitaes 


\section{Arbor Vitae-Continued}

Thuja oecidentalis Vervacueana rvervanes A v bu vitale). A true American type of compact habit. with variegated greenish yellow foliage, spring and sum mer. Broadly pyramidal in habit of growth and winter color very good.

3 to 4 feet.....\$4.00 each; 2 to 3 feet....\$3.00 each

Thuja Oecidendalis Wareana (Ware Arbor Virate). This is a small globe variety and its unusually dark green color makes it very useful. It is the darkest green of all the American Arbor Vitaes. It can be sheared to a perfect globe though if left develop naturally it is oblong.

$21 / 2$ feet.

2 to $2 \frac{1}{2}$ feet

$\$ 4.50$ each

1 to $11 \%$ feet

$\$ 3.50$ each

$\$ 2.00$ each

Ihuia orientalix (Oriental Mrbor Virac). This has the typical pressed foliage ot the Arbor Vitae family, but is inclined is aifferent from the other varieties in charactel of growth and appearance. It grows rely rapidly and can be used where mass effect is wanted, as a specimen or in a hedge. It shear's especially well and it real compact as it is inclined to grom open.

6 to 7 feet

5 to 6 feet.

to 4 feet.

$\$ 5.00$ each

$\$ 3.00$ each

$\$ 2.00$ each

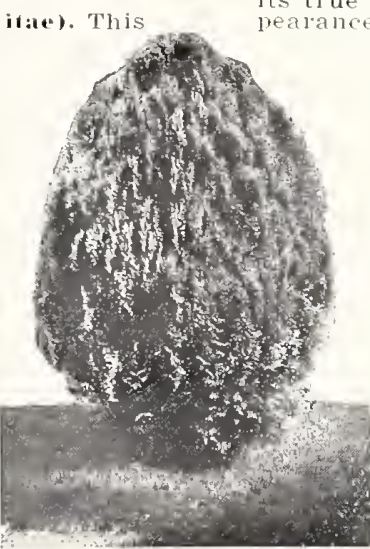

the spring growth is as attractive as any othel blue evergleen offered

3 to 4 feet......\$4.00 each: 2 to 3 feet....\$3.50 tach

Chambeguaris Pisifera (Sawara Cruress). The foliage of this resembles the Arbor vitae very much and the tree develops decidedly erect with very graceful branches. When sheared, the foliage develops ts true color especially well. It is very lacy in apside. It is a fine plant in the foundation planting where a heavy plant is wanted and on the lawn it makes an attractive specimen 6 to 7 feet 1 to 6 feet $31 / 2$ to 4 feet 1 to

$\$ 7.00$ each 5.00 each 4. 100 each .50 each

Chamareynatis Pisitera lurea (Go t d e Suvira Crurext. 'This has all the char" acteristics of the green form described above except that the foliare is a very light green or bordering on yellow. Both of these will do well in city planting where some tenderer eveloreens fail. 5 to 6 feet........... 5 .0n each 4 to 5 feet

to $31 / 3$ feet

$21 / 2$ to 3 feet

$\$ 4.50 \mathrm{each}$

$\$ 4.00$ each

3.00 each

Chathatevuaris Pixilera Plumbsa (Plnmen Cruresis. The foliage of this is a grey. sh gleen very fine cut and has a eathery appearance. It resembles a fine

Thuja orientalis Inrea Ninat (bevelumus fablen Arbor Vitae). This is without doubt the showiest of all the Arbor titae family. The color is an un usually attractive hisht especially well with us and appearance. Does especiall

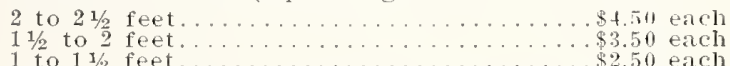

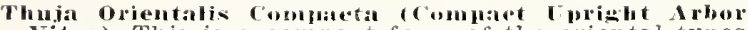
Vitae). This is a compact form of the oriental types having jts follage in veltical layers. The general shape is columnar to prinmidal, and colol of foliage dark green.

5106 feet

$41 / 2$ to 5 feet
$410+1 / 2$ feet

$\$ 5.00$ each

Japan

Japan Cypress-Chamaecyparis

Chamaecsmaris Lawsoniama Ammi (Scarab's Croress). This variety resembles the general Petinospora group except that the foliage is an attractive blue cal fashion. It is inclined to grow a little open and development. Pyamidal in habit of
growth and it kept shealed, as all valieties of this
family should be, in foundation planting it will family should be, in founi

5 to 6 feet

5 to 6 feet
4 to 5 feet
$: 1 / 2$ to 4 feet

$: \begin{aligned} & 1 / 2 \text { to }+ \text { feet } \\ & 3 \text { to } 31 / 0 \text { feet }\end{aligned}$

$2 \frac{1}{2}$ to $\frac{3}{3}$ feet

$\$ 5.00$ each

$\$ 4.50$ each

$\$ 4.00$ each

$\$ 3.00$ each

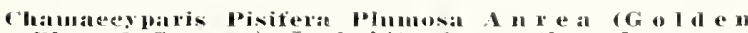
Plnmei Cxpress). In habit of growth and appearance is like the green form previously described. 'The young follage is very light green bordering on yellow and for contrast planting for foundation or lawn groups is one of the most popular.

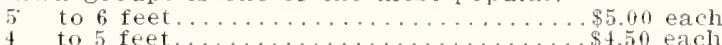

416 to 4 feet

3 to $31 / 2$ feet

$\$+00$ each

$\$ 3.50$ each

chamatesparis Pixidera Filitera ('Phreal Brauched cymess. One of the best dwart evergleens of unusual foliage, very drooping and graceful resembling cords ol threads of green foliage. Very compact and fine color looth winter and summel.

3 to 4 feet

$\$ 5.00$ each $\$ 4.50$ each

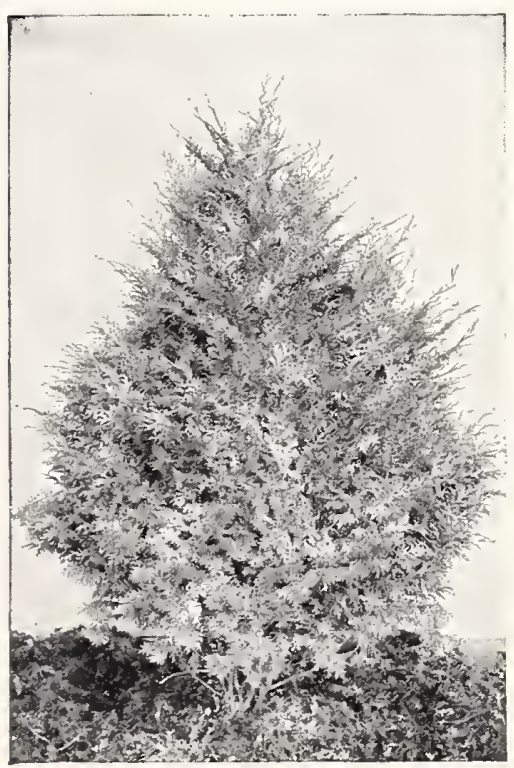

SAWARA CTPRESS.

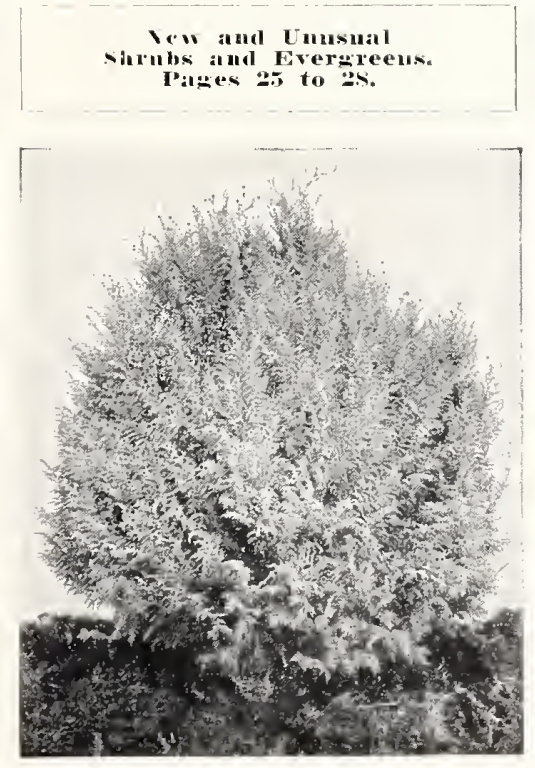

PLUMED CYPRESS,

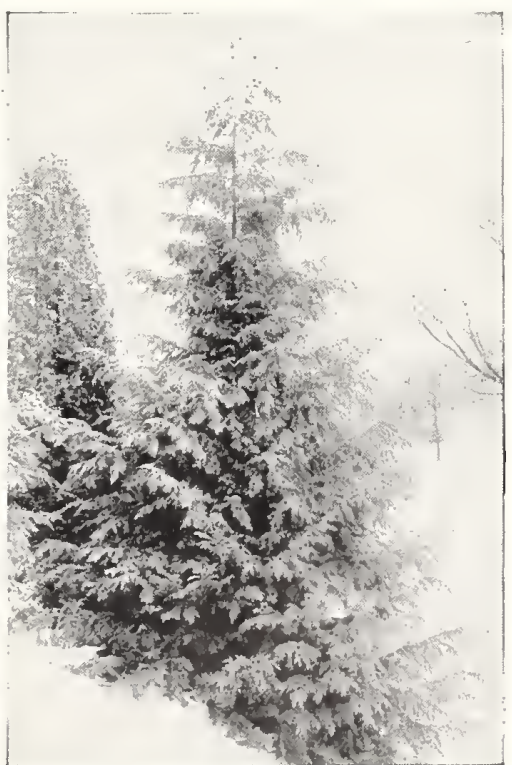

HEMLOCK-TSUGA, page 16

Our planting bookl't, which will be sent with every order, makes it easy for you to plant successfully. 


\section{Hemlock - Tsuga a}

'Isura Caubdeusis (Camadan llemlonk) We consider Iremlock the very bes of all the evergreens. It grows rapplaces it adapts itself to all conditons and if kept shealed can be wel ased as a foundation plant. If left to develop naturally it has sweeping fendulous branches that are most soft billowd when sheat ar it hanot Te duplicated appearather everons. The foliage is always a very deep green and under adrerse circumstances it is more largely planted than any other erergreen. We have saying here, "When in doubt plant 6 to 7 feet 5 to 6 fet 4 to $\$ 9.00$ each $\$ 7.00$ each 2 is to 3 feet $\$ 3.00$ each; 3 to 4 feet. t.00 ach

Tsusa Caroliniana (Carolina Hemlock). The Carolina has not been generally offered, being a more pendulous rariety than the canada Hemlock. Of moderate growth only Foliage a deep green borne in miniature wholls about the branches, It has proven hardy and quite attractive.

to 6 feet............ $\$$ i.00 each; 4 to 5 feet.

$\$ 5.00$ each to 4 feet...

$\$ 4.00$ each

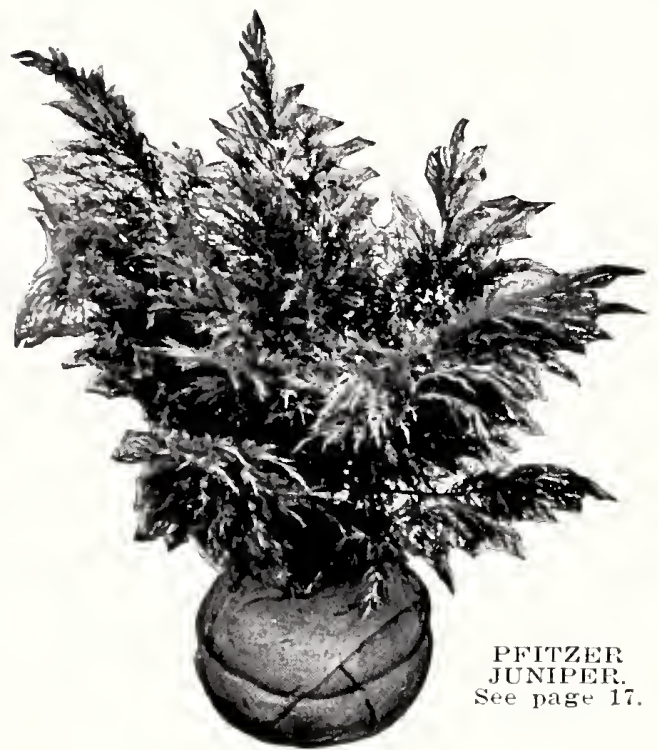

\section{Juniper-Juniperus}

Juniperus Chinensis (Chinese Juniper). This is a valuable addition to our list. It is quite columnar, and tapering to a decided point. and tapering to a decided point. and it is free of all disease. It is destined toe of all disease. erect growing evergreen favorites.

6 to 7 feet..

$\$ 6.00$ each

5 to 6 feet. $\$ 4.00$ each

Juniper Chinensis (Blne). This is a grafted form of the common Chinese Juniper, being compact, vet upright in growth. Makes a velop symmetrially.

5 to 6 feet......

$\$ 6.00$ each 4 to 5 feet.............\$ $\$ 5.011$ each

Jumiper Chimensis (Green). Like the above, a grafted form of selected green foliage and makes an attractive specimen or formal plant where symmetry is desired.

5 to 6 feet......... \$6.00 each 4 to 5 feet..............\$.00 each

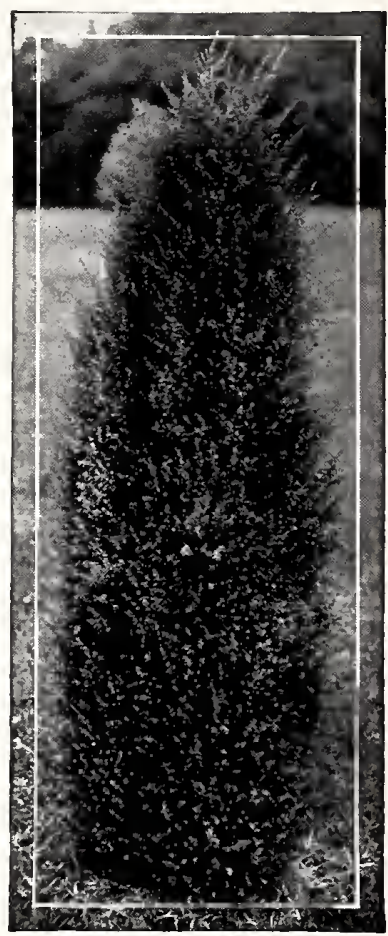

Juniperus communis hibernica, Ir·ish Juniper.

\section{It is Easy to Grow Hillenmeyer's Evergreens}

(1) Digr liole a foot larger and deeper than ball of earth; llse good soil.

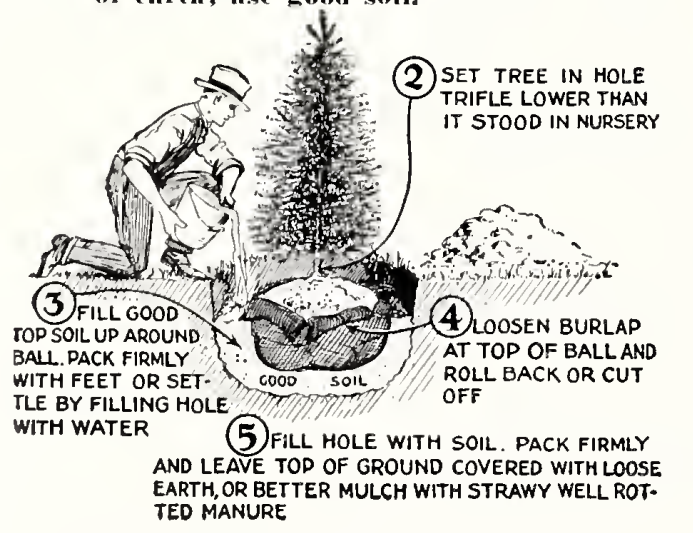

\section{CARE AND AFTER-CARE:}

Planting directions are given in the picture shown. Follow this as directed.

The common error in planting about the foundation is too close planting with the idea of immediate effect. Space wide enough to permit develop-

Pruning should consist principally of the shearing or clipping of the terminal growth in the spring just when the new growth appears. This keeps your trees compact and once they get to the lieight you want then they can be kept this way like a hedge. Don't prune too late in the summer.

Lawn trees are better left to develop naturally. Pruning is not necessary except to shape them up.

Never top or cut an evergreen below the point where it is showing green foliage. Always leave a fringe of foliage on the tips of the branches.

The dead that comes inside of the trees in the fall is natural. They shed this old growth about this time. Shearing in the summer usually causes the trees to cover this unsightliness. 


\section{Juniper-Continued}

Juniperus Chinensis Pfitzeriana (P’tzer Juniper). This is the most popular of all the spreading types. Its habit of growth, its pendulous branches and attractive foliage are strikingly beautiful. The branches are horizontally spreading and the terminals slightly drooping. It lays close to the ground and for edging larger plantings there is nothing superior. Flowing lines are especially valuable in landscape planting and this Juniper seems to fill this requirement better than any other. The follage is a grey green both summer and vinter and noted for its ability to withstand the soot and dust of cities, thriving where others fail. Another advantage is that it lends itself to serere pruning in adve it outgrows its location.

$31 / 2$ to 4 feet...............

3 to $31 / 2$ feet

$\$ 5.00$ each

$21 / 2$ to 3 feet

$\$ 4.50$ each

to $21 /$ feet

5400 each

$\$ 3.50$ each

$\$ 3.00$ each

1 to $11 / 2$ feet.

$\$ 2.50$ each

Juniperiss Communis bepressa Inrea coolden l'rosrrate. Jumper). In habit of growth and general charactelistics like the Prostate Juniper" except the foliage is a vert bright green shading to yellow. It is especially bolder.

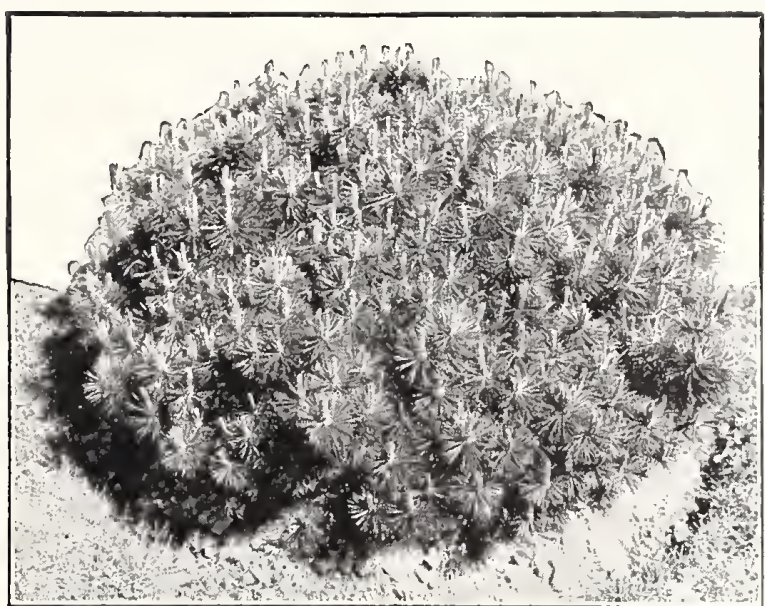

MUGHO PINE.

$41 / 2$ to 5 feet...... \$6.00 each; 4 to $4 \frac{1 / 2}{6}$ feet....... $\$ 5.000$ each 3 to 4 feet.......\$4.00 each; $21 / 2$ to 3 feet........\$3.50 each

Juniperus Communis Depressa Plumosa (Purple Spreading Jumiper). This is a very unusual variety, remaining close to the ground and in summer has a silvery reflex to the othervise gray-green foliage. In fall and winter it turns to a purplish cast that is unusual in evergreens. Fine for rock work or low planting.

4 feet $\ldots \ldots \ldots \ldots \ldots \ldots \$ 6.00$ each; 3 to 4 feet.........\$5.00 each $21 / 2$ to 3 feet........\$4.00 each;2 to $21 / 2$ feet.........\$3.50 each

Juniperus Communis Hiberuica (Irish Juniper). This is a decided columnar form and immediately attracts attention. The foliage is a glaucous green. For formal work, especially in contrast with other plants, it has decided advantage over anything you can use for such work. It is very slender in habit of growth and needs no shearing.

4 to 5 feet.......\$ 34.00 each $; 31 / 2$ to 4 feet......... 3.5 .50 each

Jumiperus lacelsa (Greek Jumiper). This is an unusually attractive dwalf pyramidal form with very compact bluish green foliage. It is vigotous in growth and not particular as to soil. Its good characteristics are rather difficult to describe but it is very pleasing. were ver used.

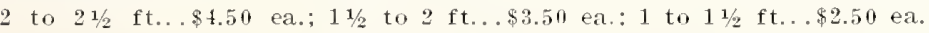

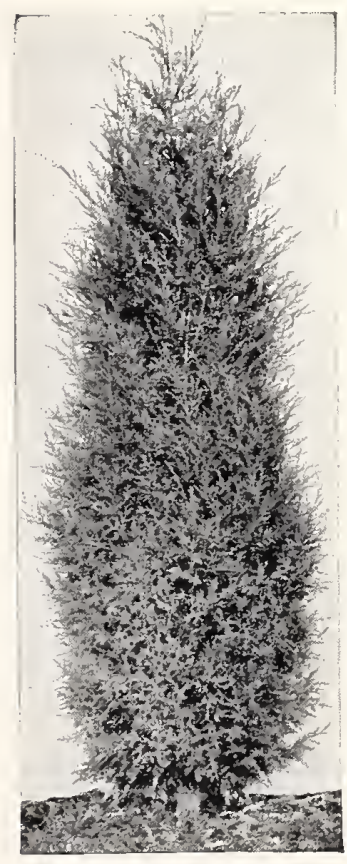

Juniperus Tirginiana.
Jumiperus Sabina (Savil Jumper). One of the best. Spreading fan shape habit, of pleasing color of dark green. Stands the pleasing color of dark green. Stands the city dust, soot, etc., exceptionally well. $3{ }_{21 / 2}^{3}$ to $31 / 2$ feet..............\$. 34.50 each $21 / 2$ to 3 feet............. 24.00 each

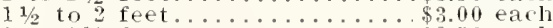

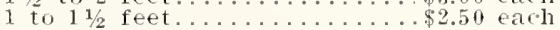

Jumiper Viruiniana (thed Cedar). This is our well known native, not half apprebest of evergreens thriving on dry and poor soil. Well shaped plants, balled and burlapped.

6 to 7 feet.

$\$ 6.00$ each

4 to 5 feet.

$\$ 4.00$ each

Juniperus Virginima Cammati (Cammats Jumiper. A fine pyramidal compact growing evergreen, wonderrul winter color and the best of its type. It is perfecty ham and never sulfers winter

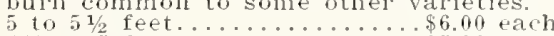
5 to $51 / 2$ feet............. 46.00 each 3 to 4 feet...............\$\$ \$4.50 each Juniperus Virwiniana Glamea (mIne Juni-
per). This is one of the best trees offered today. It grouvs pyramidal but has graceful spreading branches if left ungraceful spreading branches if left untrimn ma be had. In color peright blue and a distinct contrast with any other of this group.

of this groul

5 to $51 / 2$ feet
$11 / 2$ to 5 feet

1 to $41 / 2$ feet
3 to 4 feet.

6.00 ea

$\$ 5.00$ each $\$ 4.50$ each

\section{Pine-Pinus}

Pinus Montana Mughus (Mugho Fine). This is an excellent dwarf Pine, being globe shaped and elect branchin spling, when the new growth which seems like miniature candles completely covers the bush.

$2 \times 2$ feet

$\$ \frac{1}{400}$ each

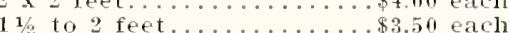
1 to $11 / 2$ feet............\$2.50 each

Piuns Stmons (White Pine). A native tree making a tall and noble specimen. Grows lapidly as evergreens go and with its long flexible, light green, pendulous needles proves one of our best trees. Can be
wind break or specimen.

4 to $4 \frac{1}{2}$ feet.

$\$ 4.50$ each

3 to 4 feet.

$\$ 3.50$ each

2 to 3 feet...........\$2.50 each

Pinus sylvestris (scotel Pine). This is one of the best Pines offered. Very quick to le-establish itself, grows Tapidy and has ability to grow very luxuriantly on high and dry ground. Its needles are shorter than either White or Austrian Pine, in habit more compact. the foliage dark green. Where auick effect is wanted this raiety will prove as satisfac tory as any evergreen.
6 to 7 feet
$\$ 6.50$ each
5 to 6 feet
$\$ 5.00$ eacl
4 to 5 feet
3 to 4 feet.
$\$ 3.50$ each

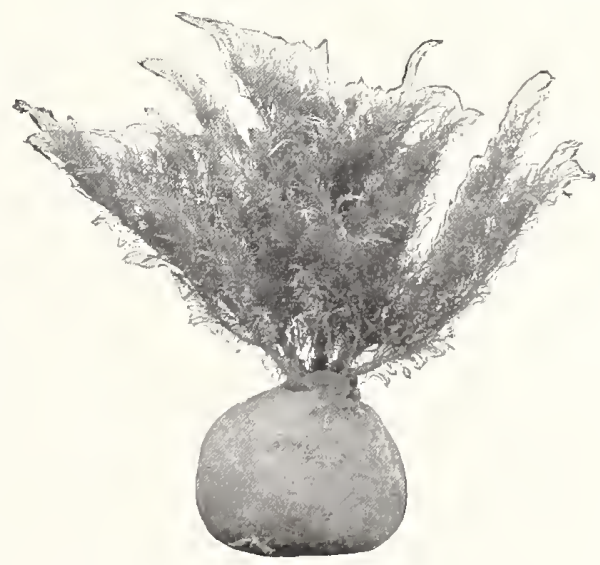

SAVIN JUNIPER.

Hot house cut flowers fade, but evergreens bring beauty to your home the year 'round. 


\section{Pseudotsuga - Dougllas Fir}

l'selud m. foliage. Fesembles the Hemlock or spruce but of a blue cast. Makes a very compact tree and can be used as a specimen or in group jlantings.

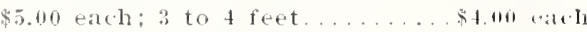

\section{Spruce-Picea}

piecor Caumlemsis white surmed. This is a very hardy evergreen with licht rreen folinge and similar in many respects to the Norway Spruce except that it is decidedly slower growing in ul small tree is wianted.

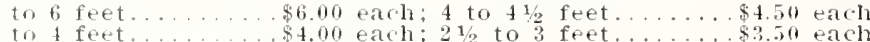

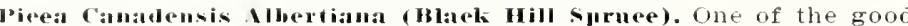
western evergreens finding their way east. In general appearance rot unlise the White spruce, but more compact and slowe croming. The most pleasing characteristic is the very brigh gieen or blue growth that appears in the spring, making one think it is a colorado Blue spruce. loeserves planting wher. such a tree is needed.

+ to $11 / 2$ feet...... $\$ 5.00$ each: $31 / 2$ to 4 leet.

$\$+.511+a \cdot h$

$$
\text { to } 3 \text { t/ feet.....\$4.00 earl }
$$

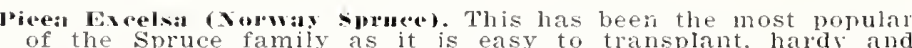
of the Spruce family as it is easy to transplant, hardy and glows rapidly. Pyramidal in shape and when used as a specimen appopriate. 'The needles are dark green.

if to $6 \frac{1}{2}$ feet......\$6.00 each; 5 to 6 feet......\$ $\$ 5.00$ each

to 4 reet.

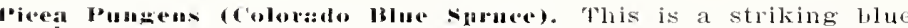
color unusual in plants and considered by many the aristocra of evergreens. Its many silver tipped branches give unusual effect especially when planted in groups of dark green collifers. We offer specially selected blues in compact trees.

$2^{1 / 2}$ to : feet........\$10.00 each: 2 to $2 \frac{1}{2}$ feet......\$.50 each

\section{Taxus-Yew}

Taxus Cuspidata (dajanese lew). The Yew is destined to lerenme one of the most ropular evergreens in America. Not only will it thrive in sunny locations but is particularly valuable for plant bears scarlet fruits. It is really a fine erergreen, a little slow to make up but most promising.

2 to $21 / 2$ feet.........\$6.00 each; $1 \frac{1 / 2}{2}$ to 2 feet

$\$ 5.00$ each

Javus Capitata (I might Jajanene Vew). This resembles the preceding except that it is a more upright form. In foliage and generaly aluearance has every chara ion planting when it is better known.

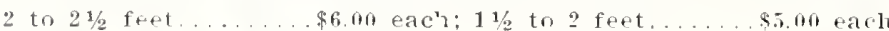

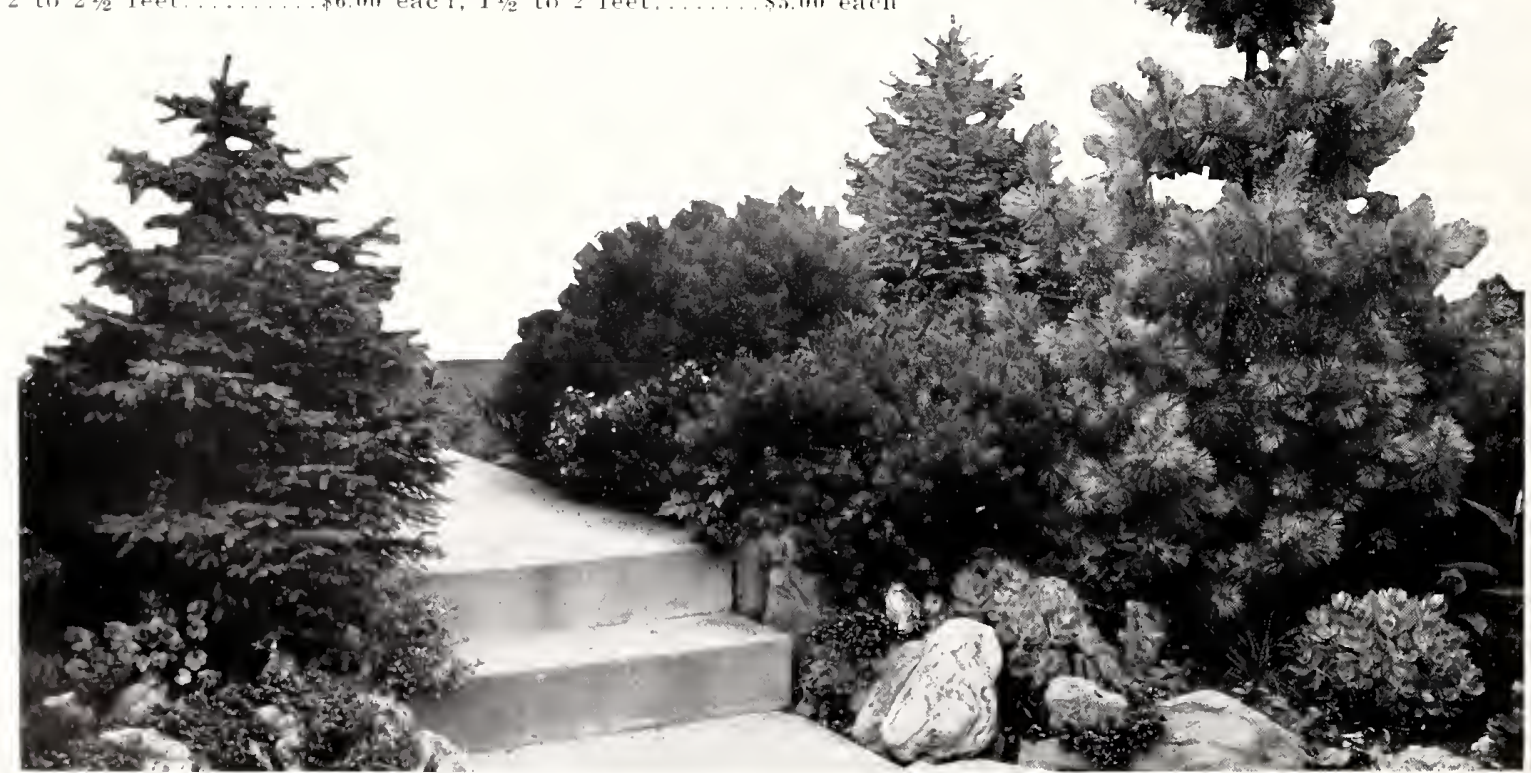

Norway Spruce (left), Mugho Pines (center foreground), White Pine (right).

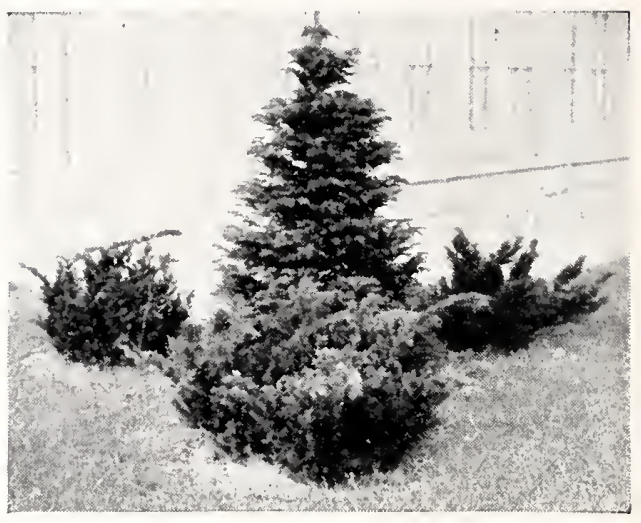

Corner planting of Jews.

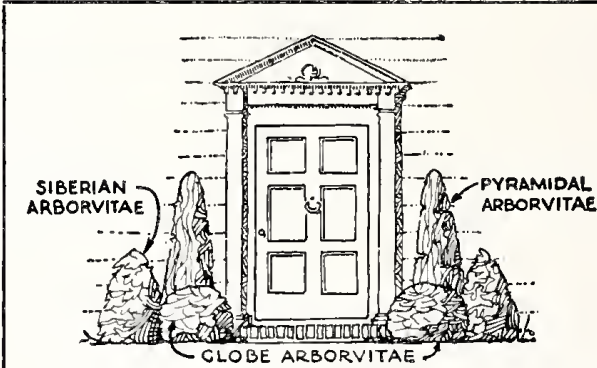

What is more attractive than a well nrranged doorstep planting? It makes the entrance inviting, frames the door way and "fills in" a sharp angle of our house. of Arbor Vitae or Juniper in the corto either side of the walk, with some intermediate growing variety as the for doorstep

planting.
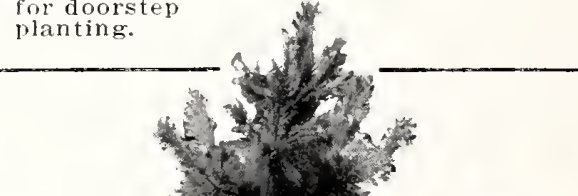

Note tall trees like the upright forms ners, a spreading or low growing type 


\section{DECIDUOUS TREES}

\section{Add Beauty, Comfort and Value}

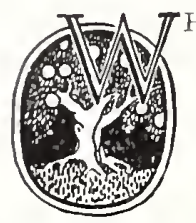

HEREVER you find them, there is a charm about shade trees with their great, sheltering, shielding, leafy arms that spread in protection. Their foliage is deeper than the greenest ivy, and, in the beauty of its passing, the scarlet of kings, as well as the purple of dignitaries might well blush.

We have these trees in all sizes. Some sizes are too large to ship. We have some that grow rapidly. while others are slow in their development. You should plant some of both types on your place so you may take out the shortlived trees when they begin to crowd.

In choosing trees for your home, study the house. If it is high and seems to stick up in the air too much, plant a tree that will tower up and spread orer it, or else one that will shoot up tall and narrow and make it seem lower by opposition to its horizontal lines, such as the eaves. If it is a low house, it can be made to hug the ground or rise higher as seems best by placing the right tree. Plant trees liberally and in groups, for they love companionship. If you do you will enjoy them and leave a legacy for succeeding generations.

\section{Acer-Maple}

Acer dasycarpum (Silver or Water Maple). Because of its quick growth, good foliage and ease to transplant, this tree is in great demand. The tree blooms very early in the spring, leaves appear prompty, being light green in color but silvery beneath, and these remain until late fall. For planting as temporary trees-that is, alternating between the hard wooded and slower growers, as Oaks,
Elms, Sugar Maples, Gum, etc., this variety is highly recommended. 12 to 15 feet, $21 / 2$ inch caliper, $\$ 4.00$ each, $\$ 18.75$ for 12 to 14 feet, 2 inch caliper, $\$ 3.00$ each, $\$ 13.75$ for 5 10 to 12 feet, 13 inch caliper, $\$ 2.25$ each, $\$ 10.00$ for 5 7 to feet, $11 / 4$ inch caliper, $\$ 1.50$ each, $\$ 6.25$ for

Ner platanoides (Norway Maple). A tree resembling the Sugar Maple in character, but of darker and larger foliage, round and spreading in habit of growth. It is really the European Hard Maple and retains this chatreter here. For lawn, as specimens or shade, to plant on streets beneath wires or for spreading ovel sidewalks, ol fol parks, cemeteries, avenues or arching over roadways, this tree is highry lecommended. Sometimes the trunks are in clined to be slightly cronked when young, but it is well known that they grow out of this unsightliness in a few yeals when planted in the open.

12 to 14 feet, 2 inch caliper, $\$ 4.00$ each, $\$ 18.75$ for 5 0 to 12 feet, 13 inch caliper, $\$ 3.50$ each, $\$ 16.25$ for 8 to 10 feet, $11 / 2$ inch caliper, $\$ 3.00$ each, $\$ 13.75$ for 5 7 to 9 feet, $1 \frac{1}{4}$ inch caliper, $\$ 2.25$ each, $\$ 10.00$ for

Acer platanoides selwedleri (Selnwedler's Maple). A tree resembling the Norway Maple in every respect except in early spring the follage is a bright purple, changing from bronze to dull green. In the fall it turns bronze before defoliating.

10 to 12 feet, 13 inch caliper, $\$ 4.00$ each, $\$ 18.75$ for 5

Acer rubrum (Med Maple). It it were not for the crooked trunks of this tree, as a lawn specimen it would prove most attractive. The young shoots are bright red in winter, blooming in early spring, a very brilliant color, with pleasing foliage until frost. Then it vies with the Oaks. Sassafras, Gum, Sumac or Sugar Maples for magnificence in color.

10 to 12 feet, 134 inch caliper, $\$ 4.00$ each, $\$ 18.75$ for 5 8 to 10 feet, $11 / 2$ inch caliper, $\$ 3.50$ each, $\$ 16.25$ for

7 to 9 feet, 114 inch caliper, $\$ 2.75$ each, $\$ 12.50$ for 5

Acer saceharum (Sugar Maple). Known everywhere and is so popular that it is difficult to keep a wellgrown supply on hand. Tree grows to be of great size, foliage of good color and in the fall turns indescribably to all tints imaginable. Being of erect, conical growth, perfectly hardy and wood of such texture that it will survive any abnormal condition of the weather, and its adaptability to all types of soils makes it a variety justly popular. Native grown, it proves valuable for the timber for hard wood finishing and also "tapped" for maple sugar. 12 to 15 feet, $21 / 2$ inch caliper, $\$ 6.00$ each, $\$ 28.75$ for 5 12 to 14 feet, 2 inch caliper, $\$ 5.00$ each, $\$ 23.75$ for 10 to 12 feet, $13 / 4$ inch caliper, $\$ 4.00$ each, $\$ 18.75$ for 8 to 10 feet, $11 / 2$ inch caliper, $\$ 3.50$ each, $\$ 16.25$ for to foet tre inch caliper, $\$ 3.50$ each, $\$ 16.25$ for

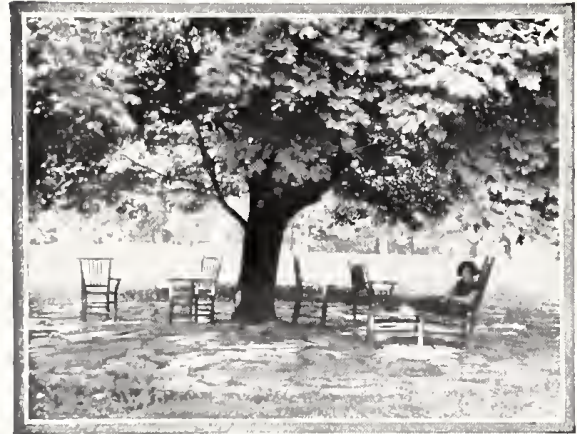

Norway Maple, fine for shade.

NEW and UNUSUA TRENS YOU SHOULD I'IANT lages 25 to 28

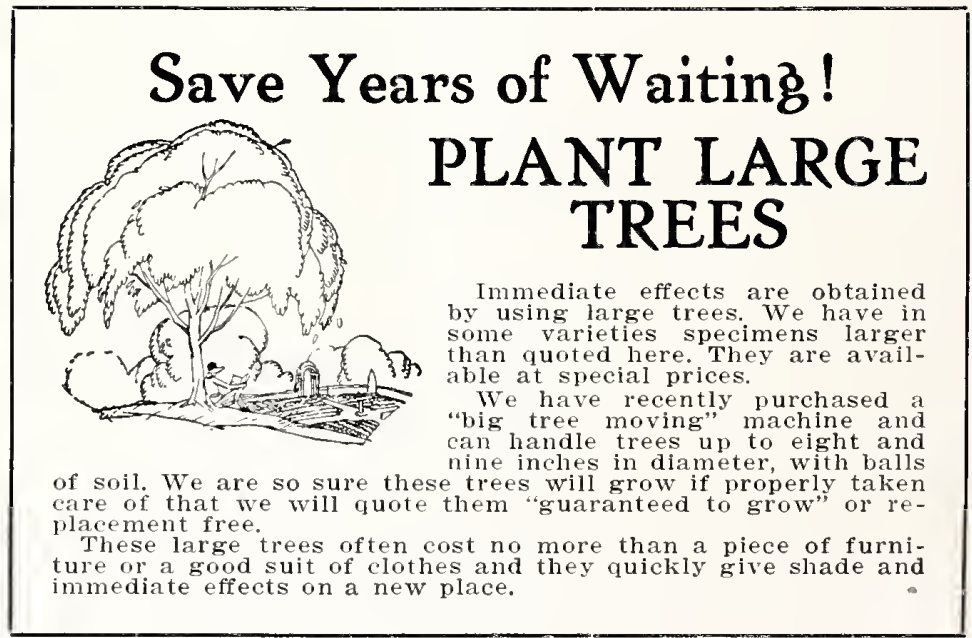




\section{Betula-Birch}

Hetula alba (ISurenean White Birall). Tree of moderately quick growth, bark almost white, erect growing with places, but will do well when planted on dry ground As a specimen greens, it malses a valuable tree for the lawn.

12 to 14 feet, 2 inch caliper...\$4.00 each...\$18.75 for 10 to 12 feet, 13 inch caliper...\$3.50 each..\$\$16.25 for

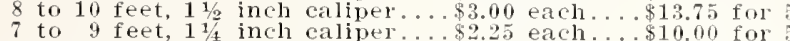

Hetula lenta (sweet Birch). Grows thirty to fifty feet and has attractive somewhat reddish bark. The Catkins are conspicuous in the spring and the tree makes an upright compact specimen.

8 to 10 feet......\$3.00 each; 7 to 9 feet.

$\$ 2.25$ each

Betula nigra (thiver Birelı). This is a native tree with darker bark, but in foliage and general characteristics it resembles the other birches.

12 to 14 feet, 2 inch caliper...\$4.00 each...\$18.75 for 10 to 12 feet, 13 inch caliper...\$3.50 each $\ldots \$ 16.25$ for

betula pendula sracilis (Cut-Leaf Wecping white birob). See page 28.

\section{Catalpa}

(atalpa bunfei (Imbrella). This tree has become popular because of its straight stems and symmetrical, roundish heads which resemble an umbrella. The tops are dwarf and while they do not grow very rapidly their wide leaves give them the appearance of much larger trees. The foliage is very pleasing and the effect obtained when planted in pairs along walks, drives, or entrances is rreatly admired.

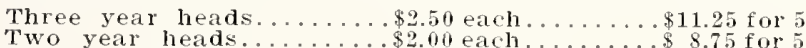

Catalpa speeiosa (Western Catalpa). This is a tree of very quick growth, and thousands of seedling trees have been planted for timber. The growth is astonishing when planted on moist ground, but it thrives on higher and poorer soil. In June the tree is a mass of white bloom and, therefore, is highly desirable when a flower effect is desired.

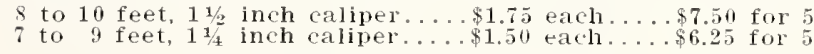

\section{Celtis-Hackberry}

Celtis mississippiensis (Inekberry). 40 to 60 feet. The native hackberry is one of the best of our trees. It is not rapid in growth but is comparatively free of disease. Grows either on dry or wet soil and the fruits are attractive to birds and children.

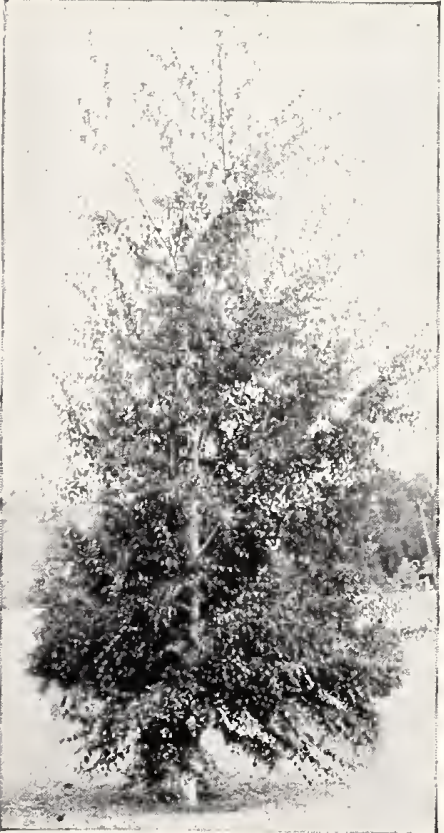

BETULA ALBA.

European White Birch.

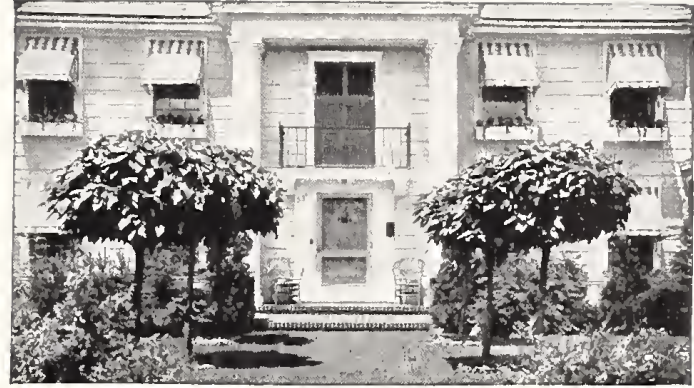

Catalpa Bungei along entrance wall.

\section{Cercis-Judas Tree}

Cercis eanadensis (Itedbud or Judas Tree). A native of our woods, literally covered with its red or pink blossoms early in the spring before it opens its leaves. It is an early harbinger of spring, blooming in April. It is a small, shapely tree; its wood is very tough, and its leaves, large and very green in color. It may be used in lieavy mass-planting of shrubs, with White Flowering Dogwood or against evergreens, or white Birch, to furnish pleasant contrast.

7 to 9 feet. $\$ 2.00$ each; 6 to 8 feet. $\$ 1.75$ each 5 to 6 feet. $\$ 1.50$ each: 4 to 5 feet. $\$ 1.25$ each

\section{Cornus-Dogwood}

Corums florida alba (White Dowwool). A native tree, well known to everyone. There is hardly a woody plant that grows, quite as useful as our native Dogwood. Its blossoms are conspicuous, coming early in the spring. The foliage is attractive all summer, and, in the fall, colors beautifully with red berries that lang on most of the winter. It is beautiful at all seasons of the year. It can be used as a specimen, or in groups, as a background for shrub borders. When planted in contrast with bright, flowering plants, like Redbud, it is bright, flowering
especially showy.

6 to 7 feet.....\$2.50 each....

$\$ 11.25$ for 5

5 to 6 feet.....\$\$ $\$ 2.00$ each

4 to 5 feet.......\$ $\$ 1.75$ each.

When balled and burlapped, $\$ .25$ extra for each. 10 to 12 feet....\$\$.00

Cormus florida mora. See page 25.

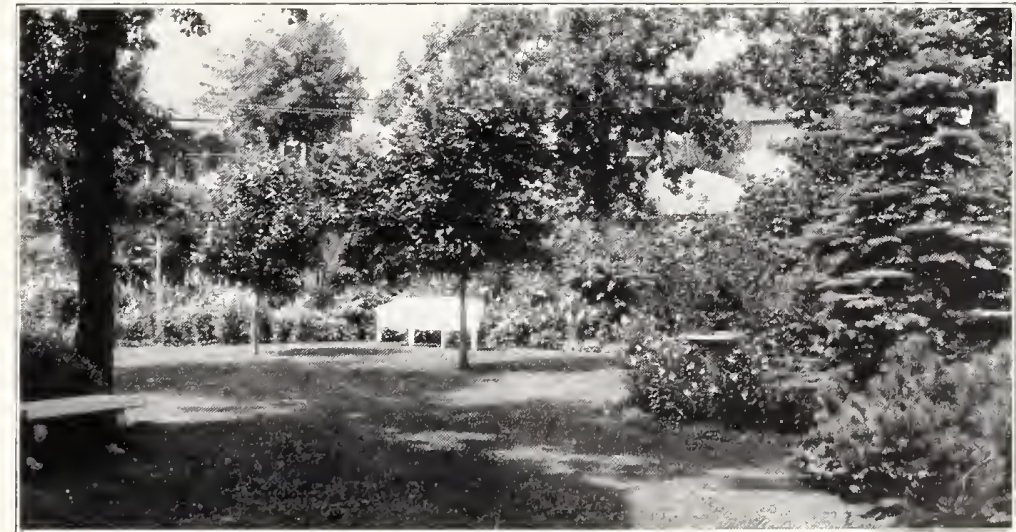

BUDGET IOUR PIANTING

Tirtually all nursery stock grows in zalue as cuell as beauty ath each year's growth. This is not true of any other thing about the home grounds. This is why properly planted homes prove more attractive each year. We can help you with your planting and also help you out on your budget payments. Details on inquiry. Invest in some trees and plants and then see them increase in value. Why not allow a certain sum every year for some planting? Hillenmeyer's quality stock insures your success. If it isn't satisfactory on arrival we will make it so. Prices, too, are the lowest in years.

Order early. We ship at the right season for planting. 
Fraxinus-Ash

Hlue Ash, Green Ish, American Ash. We offer these three varieties which are not unlike in appearance and which are all native. The whole group is desirably successiul in dry, moist, and lime solls. These should be nore generally planted, especially in the paddock and for reforestation purposes.

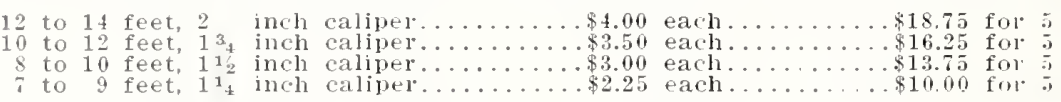

\section{Ginkgo-Maiden Hair}

Giukgo biloba (Maiden Ilmir). A conifer that is deciduous. It is allied to the Pine family. On close examination of the leaves, one will note the aborted Pine needles bound together into a solid leaf. It is of Asiatic origin and carries with it the indescribable oriental appearance in the shape and poPerfectly hardy; here and in the East largely used for arenue trees.

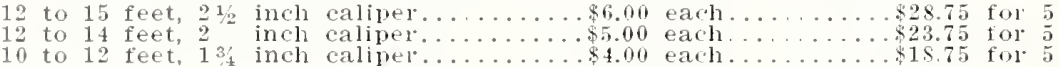

Gymnocladus-Kentucky Coffee

Gymuchidus dioita (hentueky Coffee 'Tree). A native of noble proportions glowing rather irregular in shape with blue green foliage. Resembles the Walnut tree. Fine for heavy clay soils.

10 to 12 feet, 13 inch caliper

$\$ 2.00$ each

18.750105

Halesia-Silverbell

llalciala. See page 8 for description.

\section{Juģlans-Walnut}

\section{Hertilisens \\ libr Trees \\ liage 51 .}

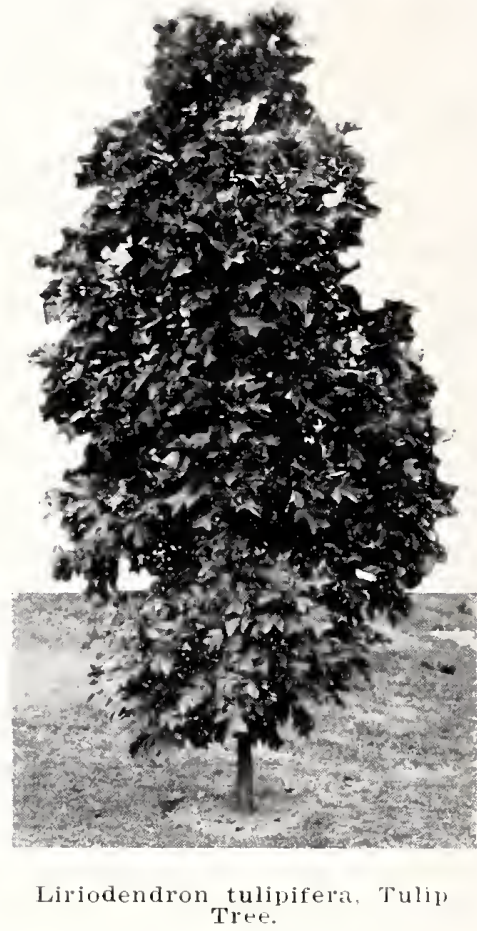

Koelreuteria-Varnish Tree trecocious of the nut bealing trees. In growth, it is rapid in making a lound-headed tree. If you want nuts quiclily, plant Butternuts. 8 to 10 feet......\$\$2.00 each ......\$\$.75 for 5 6 to 8 feet.......\$1.50 each......\$\$6.25 for to 6 feet.......\$1.00 each.......\$3.75 fü

Jülas nigra (Hanck Walunt). Our native forest tree for which there is demand for planting. Too wel known to describe. One of the noblest of our fores trees.

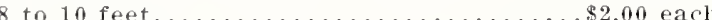

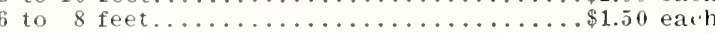

5 to 6 feet...................\$1.00 each

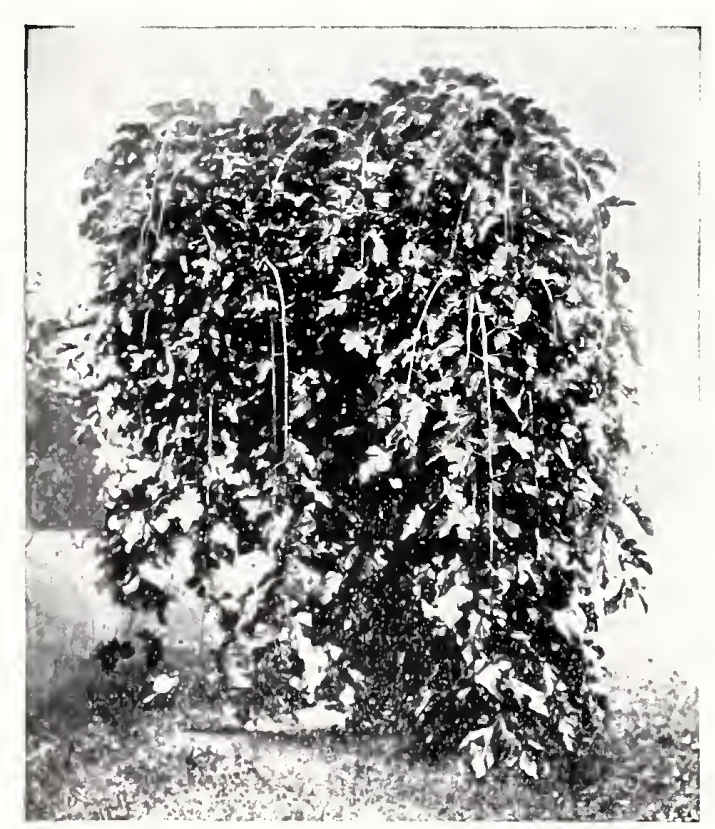

Morus, Teas Weeping Mulberry. See page 23.

\section{Liquidambar - SweetBum}

Liquidambar styracifua (sweetgum). Another native tree not appreciated. It is not of rapid growth nor especially easy to transplant, but the glossy foliage in summer, the brilliant color in the fall and the unusual appearance of the young branches with make it especially valuable.

10 to 12 feet, $13 /$ inch caliper, $\$ 4.00$ each, $\$ 18.75$ for 5

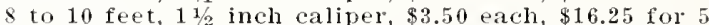
7 to 8 feet, $11 / 4$ inch caliper, $\$ 2.75$ each, $\$ 12.50$ for 5 6 to 8 feet, 1 inch caliper, $\$ 2.00$ each, $\$ 8.75$ for 5

\section{Liriodendron-Tulip Tree}

Liriodendron tulipitera (Tulip Poplar). This is one of the finest of native trees, glowing to be very large. It belongs to the Magnolia family, bearing tulip shaped, yellowish blossoms. Its leaves are large and a very dark green. Grows quickly after it becomes astablished.

12 to 15 feet, $21 \%$ inch caliper, $\$ 5.00$ each, $\$ 23.75$ for 5 12 to 14 feet, 2 inch caliper, $\$ 4.00$ each $\$ 18.75$ for 5 10 to 12 feet, $13 / 4$ inch caliper, $\$ 3.50$ each, $\$ 16.25 \mathrm{for}^{\circ} 5$ 8 to 10 feet, $1 \frac{1}{2}$ inch caliper, $\$ 3.00$ each, $\$ 13.75 \mathrm{for}^{\circ} 5$ 7 to 9 feet, $1 \frac{1}{4}$ inch caliper, $\$ 2.25$ each, $\$ 10.00$ for 5

We have some trees larger than the regular grades, which are excellent specimens. Write us for prices and information. 


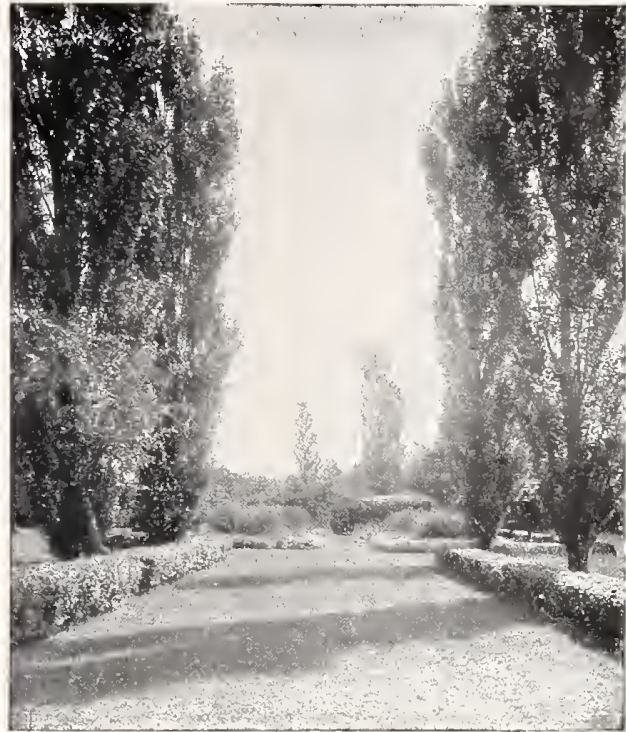

LOMBARDY POPLAR.

\section{Magnolia}

Masuolia acmminata (Cueumber 'lree). A Well known native $m$ oul mountains, which grows conical in shape and has large glaucous leaves, malring it attractive. The flowers are fragrant, usually of dull, white color followed by elongated green seed clusters which later turn coral. Very satisfactory.
5 to $6 \mathrm{ft}$.
$\$ 2.00$ each
8.75 for 5

Iasmolia zrandiflora (Sonthern Masmolia) This is a purely Southern Magnolia and while it usually reaches a medium height it does not do well on limestone soil. It seems to thrive best in moist, porous soils. It demands an abundance planters are well repaid, the flowers being especially large, and attractive and very fragrant. The

5 to 6 feet...\$4.00 each...\$18.75 for 5 4 to 5 feet...\$3.50 each ...\$16.25 for 5

Masnolia somlangeana (Sameer Maguolia). See page 27 .

Mawnolia mlauca (Sweet Hay). See page 10.
Nyssa-Sour Gum

Msal sylutica (somr or Tupelo Gum). This is one of the finest trees known for all fall coloring. It has long, narrow, glossy leaves and is rather slow growing. Very attractive at all sea sons. Not often offered nursery grown. Try some.
5 to
+10 feet
4 feet
$\$ 2.00$ each
$\$ 8.75$ fo

\section{Oxydendron-Sour Wood, see page 10}

\section{Platanus-Sycamore}

Platiuus wecidemtilis (Sycamore). A native sometimes thought too common to plant. However, where a tree for quick effect is wanted, one clean in habit of growth, luxuriant of foliage and easy to transplant, this lesson of Nature in distributing it so liberally should be accepted. The bark is silvery or grayish in for a verae, street, lawn and (

12 to 15 feet, $21 / 2$ inch caliper.

12 to 14 feet, 2 inch caliper.

10 to 12 feet, 13 inch calipel.

7 to 9 feet, $11 / 4$ inch caliper

$\$ 4.00$ each
$\$ 3.00$ each
$\$ 2.25$ each
$\$ 1.75$ each
$\$ 1.50$ each

$\$ 18.75$ for

$\$ 10.00$ for

$\$ 6.25$ frit

(amin comean pametree). 70 to so feet similar to our native variety and not quite as l'ipid, but for city planting is excellent. Its leaves are not quite as lalge alld coarse; the bark is gray instead of white. A gereral favolite for quick, maturing trees. Prices as above

\section{Populus-Poplar}

Populus nisra italicat (Lombardy Poplarb. A tall slender tree reaching great heights, very easy to transplant and of most
rapid glowth. Specimens often leach 50 feet with a spread of less than ten feet, and for this reason when tree plantings are needed for narrow places, between buildings, congested lawns, narrow avenues, this may be used with great satisfaction. Because of its great height and quick glowth it is commendable for backglounds of buildings, to add character to plantings or to offset straight or bare lines. Further for screening unsightly vievs, fire protection from close buildings or wind brealisand all for quick effect we unhesitatingly recommend this variety. A false impression prevails that it sheds its leaves early, but this is a misapplehension, as the tree is healthy in groivtl and foliage. Not the same as Carolina Poplar.
0 to 12 feet, $1 \frac{1}{2}$ inch calliper.
8 to 10 reet, $1 \frac{1}{1}$ inch caliper.
7 to 9 feet, 1 inch caliper
$\$ 1.50$ each
$\$ 1.25$ each
$\$ 1.00$ each
6.25 for 5
5.00 for 5
3.75 for

Poulus simoni (sinuon's Poplar). Does not grow quite as tall as Lombardy and more spleading. The foliage is smaller and very glossy. A tree of Chinese origin but whether it will escape the ravges of canker prevalent on some rarieties, time will only tell. It looks promising.

10 to 12 feet. $\$ 1.75$ each; 8 to 10 feet.

$\$ 1.50$ each

\section{Prunus-Flowering Cherries}

Prums subhirtella pendula (veeping Japanese Flowering clecrs). As a lawn tree this can hardly be excelled. Its sweeping, penin spring. Alu ornament in any lavm. For spring planting ont rrafted trees, 5 to 6 feet........ $\$ 4.00$ (4)

Malus-Flowerinz Crab, Morus-Mulberry Morus alba pendula (Weepins Iulberry. A very odd tree, im nediately attractive with its long sweeping branches that touch the ground. It is grafted On its parent stock-Pussian Mulberry, and is entirely free of all diseases. Bears some fluit.
"Two year heads....\$3.00 each $\$ 13.75$ for

Horus tatarica (IEnsian Vulbery). This makes a roundheaded tree, ruick of glowth and very profuse foliage. It is wonderfully productive of frui and for any one wishing to attract birds, it cannot be sur-
passed. If planted in chicliem passed. If planted in chitit runs it will produce frult considerably smaller than our native variety but the tree bears so profusely that it is vissible for considerable distance. $\&$ to 10 feet.......\$ \$1.75 erch 7 to 9 feet......... $\$ 7.50$ each $\$ 6.25$ for

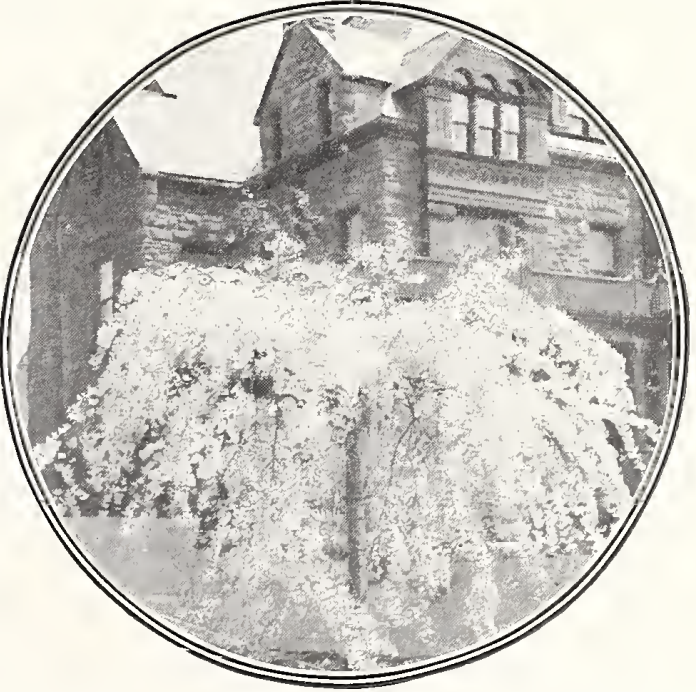

WEEEIXG JAPANESE FLOWERING CHEPRT. promus serrmintal (Janinnexe Flowering (hä ries). For spring plint ing only, Blooming il April, they are the earliest trees in blos som. There is no flowering tree that has the beauty and charm of these wonders of the orient. As the demand incleases our variet list will grow, but the ones listed here are the choicest varieties for planting. Like all cherlies they are shallow rooted and do not neces sarily have to have rich ground in which to thrive. Niden: Large, double blush pink va double blush pink va has. medium growth. slarofinin: Very large double pinkish white double pinkish white fowers. Kank:11: Deep rose. Late and very double. Spring planting only

4 to 5 feet...\$2.50 ench $\$ 11.25$ for

The flowering cherries are beautiful new introductions, but many prefer the crabs and doguoods. 
Quercus-Oak

Querens allo:a (White (Oak).

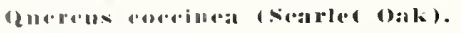

Wh have tine specimens of these in latgel sizes.

Cuotiltiolls 1011 abplicatiols.

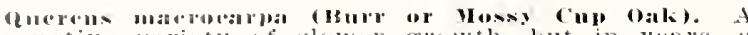
llative larety of slower glowth. but in yeals, at colitge of heal"y texture Fol pelmaneney it has no uperiol. prefels a moist or deep soil.

12 to 15 feet, "2, inch caliper, $\$ 6.00$ each, $\$ 28.75$ tor 12 to 1 feet,, inch caliber, $\$ 5.00$ each, $\$ 2375$ for 10 to 12 teet 13 inch caliner, $\$ 4.00$ eitch, $\$ 18.75$ for to $10 \mathrm{feet}, 1$ 1., inch caliper, $\$ 3.50$ each, $\$ 16.25 \mathrm{for}$

queraus palustis (F'in bak). Of all the Oaks this is prefelred. Pelfectly symmetrical from the base ut, alld in fint for beauty, symmetry and durabis not found in any othel tree It is the plant more rapid of grow th and may be used in an capacity, whether shade, sperimen, avenue, cemetely ol latk tree. If one is a little patient the reward cortal to it and when a hard wood tree is wanted for ans loca tion we unhesitatingly recommend in Oak. If you knew it as we do you mould be equally enthused. 12 to $15 \mathrm{feet}, 212$ inch caliper, $\$ 6.00$ each, $\$ 28.75$ for 5 12 to 14 feet, 2 inch caliper, $\$ 5.00$ each, $\$ 23.75$ for 11) to 12 feet, $13_{4}$ inch caliper, $\$ 4.00$ each, $\$ 18.75$ fol 8 to 10 feet, $11 \%$ inch callipel, $\$ 3.50$ each, $\$ 16.25$ for 7 to 9 feet, $11 / 4$ inch calliper, $\$ 2.75$ each, $\$ 12.50$ for 5 Have fine stock in extra large sizes.

Quereus rahra (Hed Oak). Not as compact as Pin Oak, equally as rapid ind not at all dificult to transplant. Red oak is nevertheless very satisfactory. Leaves tree will glow on any type of soil. Suptree will gl*ow

Hy limited. $21 \%$ inch ealiner, $\$ 6.00$ each

12 to 15 feet, 2,2 inch ealifer, $\$ 6.00$ each, 12 to 14 feet, 2 inch ealiper, $\$ 5.00$ each, 10 to $12 \mathrm{feet}, 13$ inch caliper, $\$ 4.00$ each, $\$$ tr 10 feet, $1 \frac{1}{1 / 2}$ inch caliper, $\$ 3.50$ each,
$\$ 16.25$ for 5

\section{Rhus-Sumac}

For description see shrubs, nage 11

\section{Salix -Willow}

saliv bablomial (Weeping Willow). A tree of stately appearance with long foliage in ever breeze quick to take hold when tremplanted, will give a finish to a lawn not whtained in any other ish to a lam not obtained in any other tree. This, too, makes a good sereen ground thrives with unusial vigor.

8 to 10 feet...\$2.0 each...\$\$.75 for 5

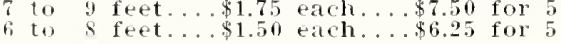

saliv caprea (Pussy willaw). See page 11 for description and price.

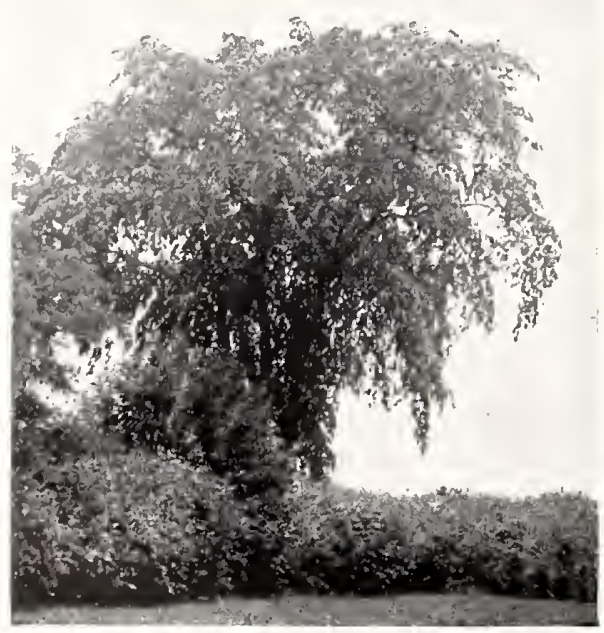

THE ELM. Most beautiful of all shade trees.

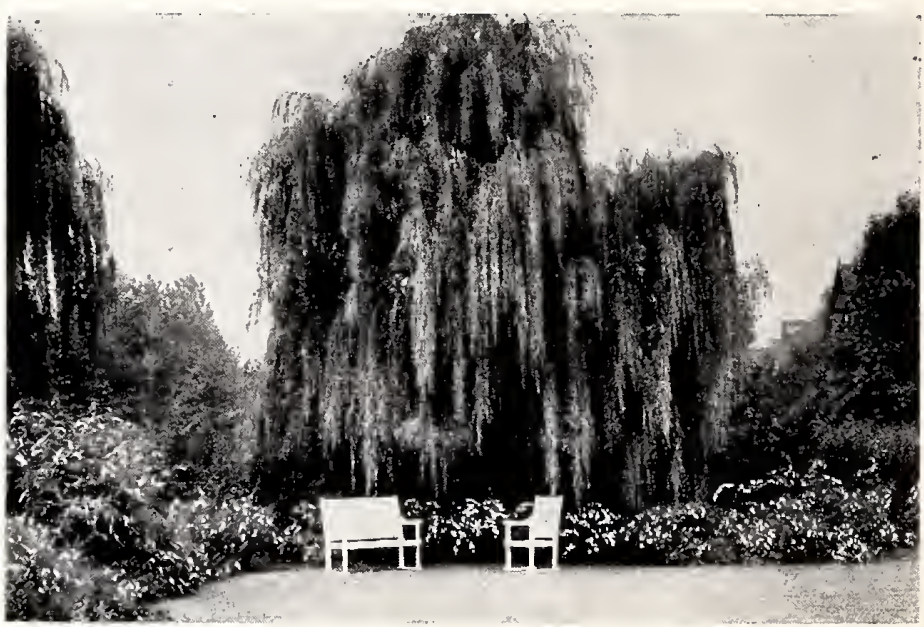

Weeping Willow as a background for the Outdoor Living Room.

\section{Sorbus-Ash}

Sorhus aucuparia (Guropean Mountain Ash). See page 26

\section{Tilia-Linden}

Tilia amcrieana (Mmerican Iinden). Sometimes known as Basswood. This native tree is very attractive and will grow rapidly when planted in low ground. The leaves are distinctly largei than other varieties, branches pendulous in habit of growth and makes an excellent shade tree under favorable conditions.

12 to 14 feet, 2 inch caliper....\$\$.00 each....\$23.75 for 5

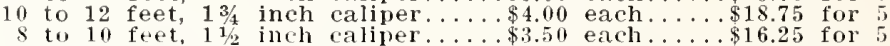

l'ilia vuläaris (Eumpean Lineten). Similar to the American Linden except the tree is more compact, leaves are smaller and the tree develops into a more shapely specimen. In the nursery row it is inclined to be awkward but soon develops into an excellent specimen where a small compact tree is desired.

$\$$ to 10 feet........\$3.50 each; 7 to 9 feet.......\$2.75 each

\section{Ulmus-Elm}

Ulmus :mericam: (Americam Elm). A tree of unusual vigor, a native too well known to describe. It is rapid of growth, with its long, spreading and pendant branches forming giant arches over roads and streets or as a lawn tree is quick to make a marked effect. The wood is tough, the leaves are noderate in size and make a permanent tree for shade. The beetle that defize and make a permanent tree for shade. The

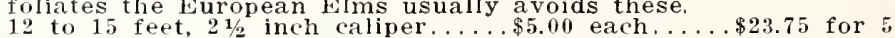

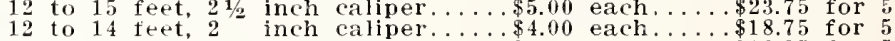
12 to 14 feet, 2 inch caliper....\$4.00 each ....\$18.75 for 5 10 to 12 feet, $13 / 4$ inch caliper....\$\$3.50 each ....\$16.25 for 5

Uluus amerieama molime. See page 26.

Ulmus pumila. See page 27 


\section{Hillenmeyer's Special Offer of UNUSUAL TREES \& SHRUBS}

\section{Some Things New and Different}

On this and the three following pages we present a number of the more unusual and interesting varieties that are not so commonly seen in general plantings. Distinctive as these are, each in some outstanding way, such as rare beauty of spring or summer blossom, unique color of bloom or foliage, length of foliage season, they are not at all unusual in the sense of being difficult to grow. In fact, aside from their distinctive character of beauty, these plants are unusual chiefly in being less familiar and generally overlooked in the average plan of planting.

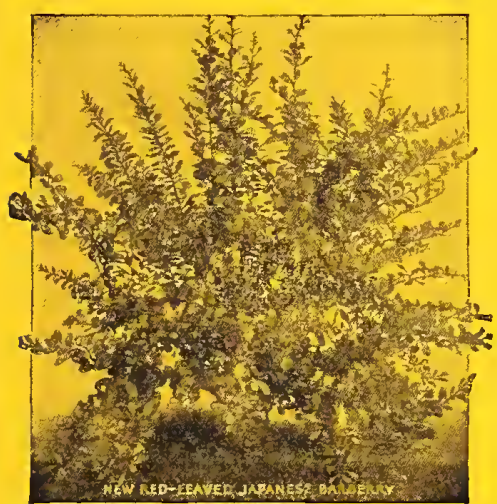

New Red-Leaved Japan Barberry

(Berberis Thunbergi Atropurpurea)

This is a comparatively recent introduction, and while not as strong and hardy as the more common Japanese variety, it is unique and interesting. From the earliest leaf in the spring until fall, the foliage is of a bright red hue. Growing among the general greenery of other shrub plantings, it spots the mass with vivid color interest. It needs full sunlight, as even partial shade dims its brilliant color to a bronze or purple.

3-year, No. 1 plants.... .5c each 2-yeal, No. 1 plants. ...60c each
Be sure and include a few of these unusual plants with your order.

\section{Pink Flowering} Dogwood

\section{(Cornus Rubra)}

The most delightful of the Flowering Dogwoods.

This is not a new or uncommon tree, by any means, but one too often overlooked as a means for beautifying home grounds. Dogwood blossoms are everywhere loved for their fresh beauty and welcomed as one of the earliest signs of spring. The common white variety may be better known but this pink flowering type affords the loveliest display. No other spring-flowering tree is quite so boldly beautiful in bloom. Even if slightly more costly than others at first planting, no other tree yields such hardy and continuous pleasure. Our trees come balled and burlapped to insure safe and sure growth. Once started, they need but simple care. Like the white flowering kind, the leaves of this dogwood color attractively in the fall.

4 to $5 \mathrm{ft}$ trees, Balled and Burlapped...........\$4.50 each

3 to $4 \mathrm{ft}$ trees, Balled and Burlapped............\$3.5o each 



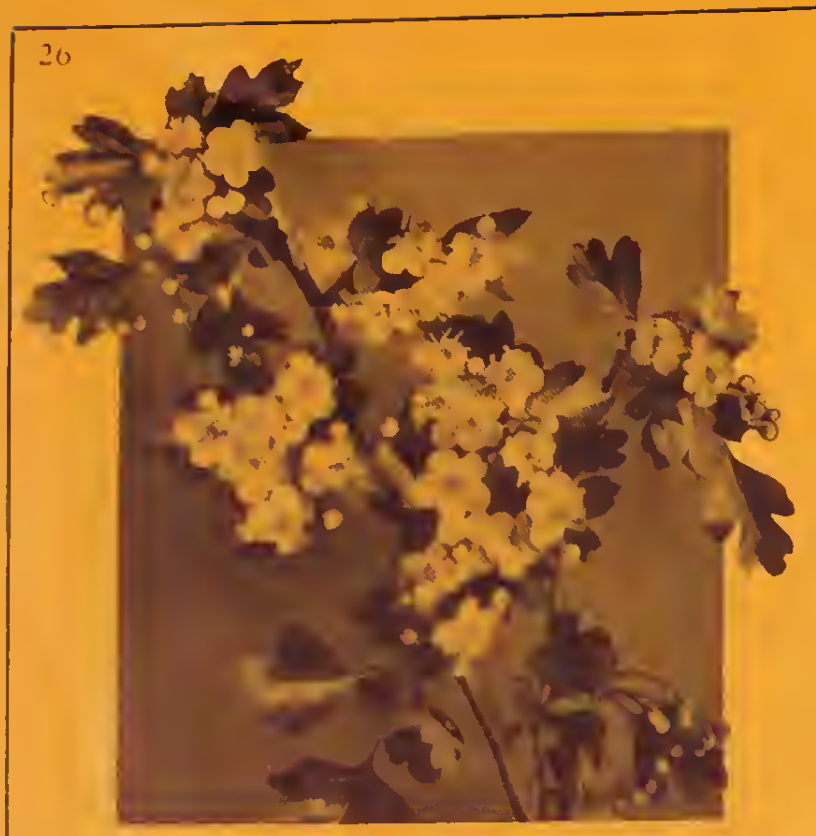

Flowering Thorns

English Hawthorn. (Crataegus Oxyacantha.
For years there has been a steadily growing
demand for English Hawthorns. This variety

demand for English Hawe the tor. hedges, or in

shrub borders. In the spring it is a mass o
sragrat flowers which literally cover the tree.
It will grow twelve to fifteen feet in height;

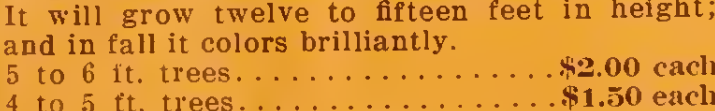

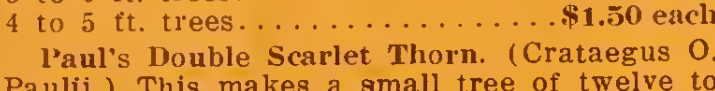

Palli.) This makes a small tree of twelve to
fifteen feet, and in the spring is a mass oof
double brilliant red flowers on every twig.

double brilliant red flowers
Shipped Balled and Burlapped.

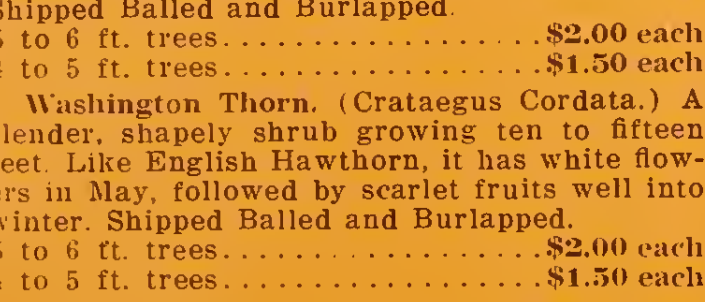

European Mountain Ash

(Sorbus aucuparia)

While this tree naturally does better in
cooler climates, still, in our latitude, it will

grow 20 to 30 feet in height. Almost everyon
laas seen and admired Mountain Ash with its
great clusters oo

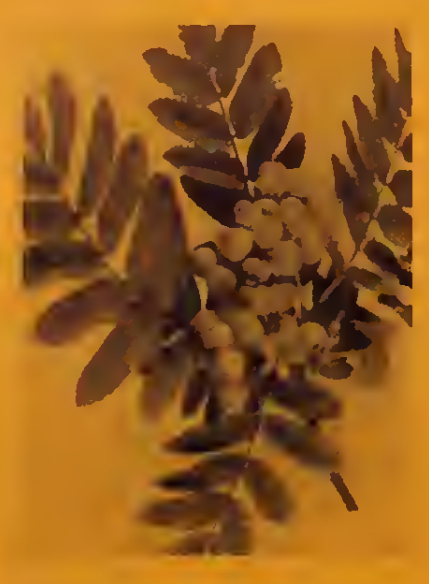

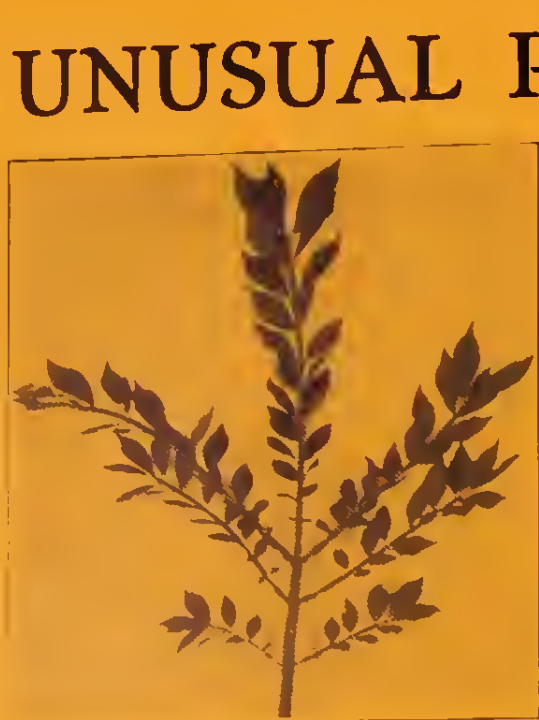

Corkbark Euonymus

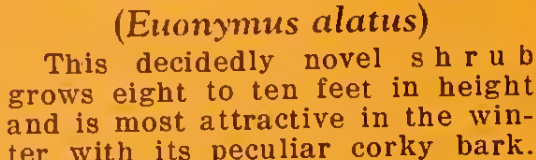
ter with its peculiar corky bark
The foliage is a shing yreen, whicl colors to a brilliant rose in the
fall. The small red berries are borne in interesting containers
that are bright orange color as they open. This is a Japanese
shrub that will grow in shade or sun equally well.
3 to 4 ft. size .......\$1.00 eacl
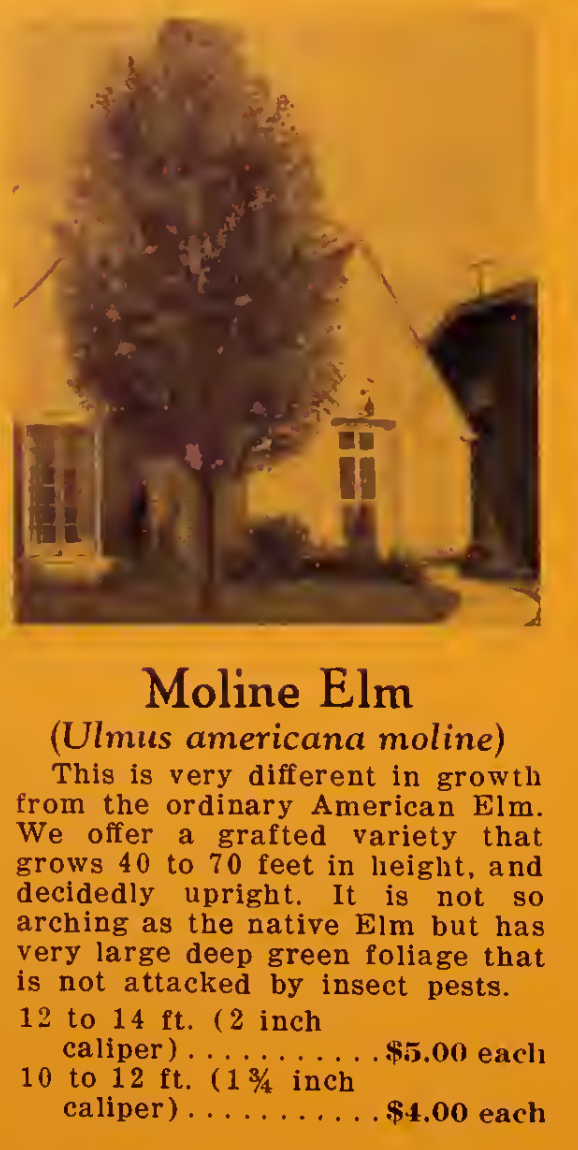

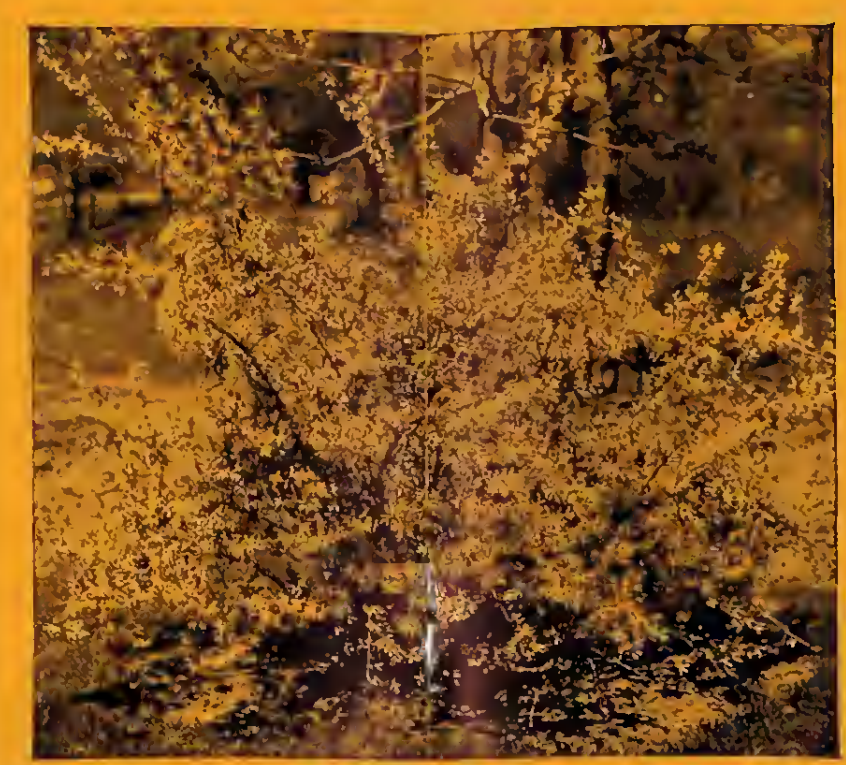

Showy Border Golden Bell (Forsythia spectabilis)

Here is a beautiful shrub that grows five to six
feet tall. While it has not been known, nor widely

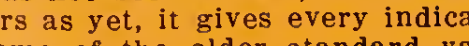
rieties of shrubs. The flowers are large. of a rich
golden yollow calor and the growth of the plan golden yellow color; and the growth of the plan
is more compact than other varieties. 3 to $4 \mathrm{ft}$. size.

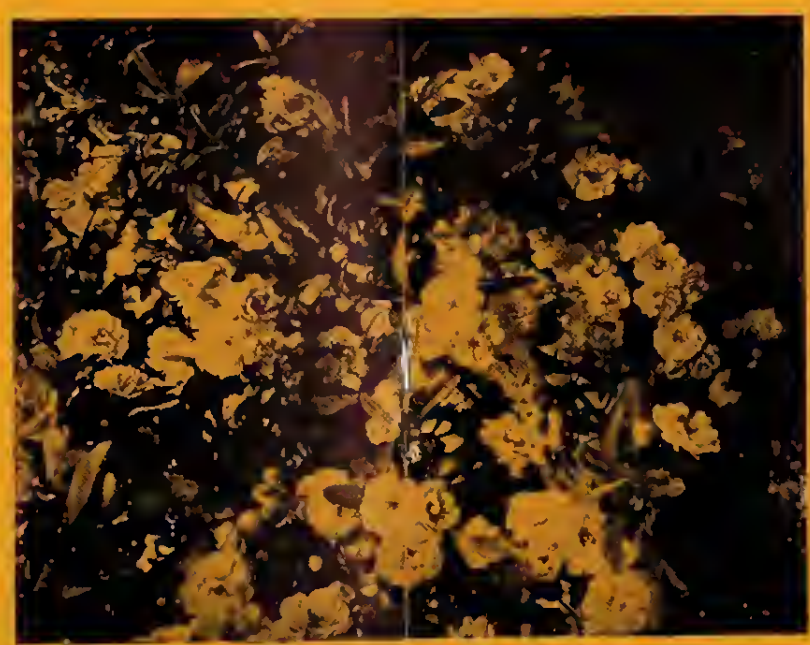

Bechtel's Flowering Crab

(Malus ioensis plena)
The unique beauty of this shrub lies in its fra-
grant blooms which are of the double-flowering type, the individual blossoms resembling minia lure roses; borne in clusters of decompact, uprigh
habit. The tree itself nnakes a complo specimen, sometimes over 15 feet in height. It cal be most effectively planted in masses, in the border
ar as specimen plants. The flowers are exceedingly (ragrant.

4 to $5 \mathrm{fth}$. trees.
3 to $4 \mathrm{ft}$ trees.

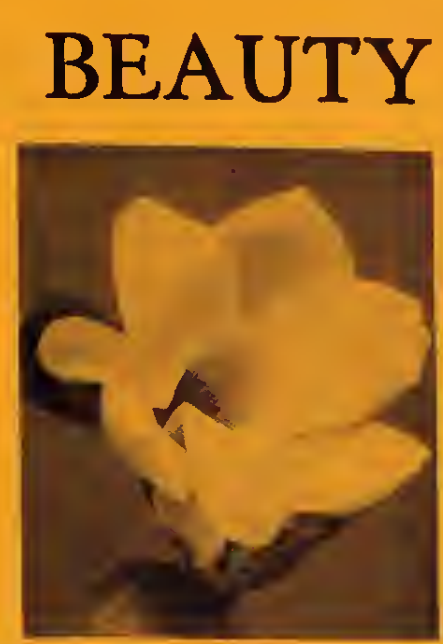

Saucer Magnolia Magnolia soulangeana) Erroneously called "Tu-
the
Tree" because of it mass of tulip-shaped blos-
soms that bloom in the spring even before the foliage appears. No spring
flowering plant makes anythis variety of Magnolia offers. The towers are a and when in full bloog this shrub is a joy to be-

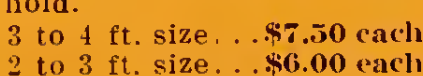

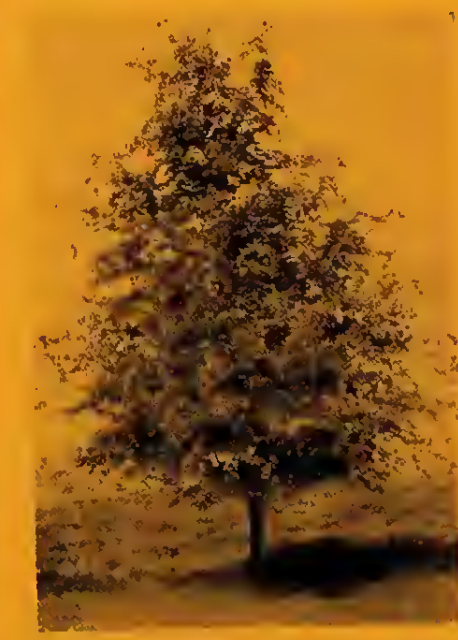

\section{Chinese Elm} (Ulmus pumila) A tree that is attracting
lot of attention for its
and lapid as the Silver Maple. conditions it may do ever better. The peculiar thing
bout it is it likes high. dry ground rather tha 10 to $12 \mathrm{ftc} \ldots . . \$ 2.25$ eacli
8 to $10 \mathrm{ft} \ldots \ldots \mathbf{8 1 . 7 5}$ eacli

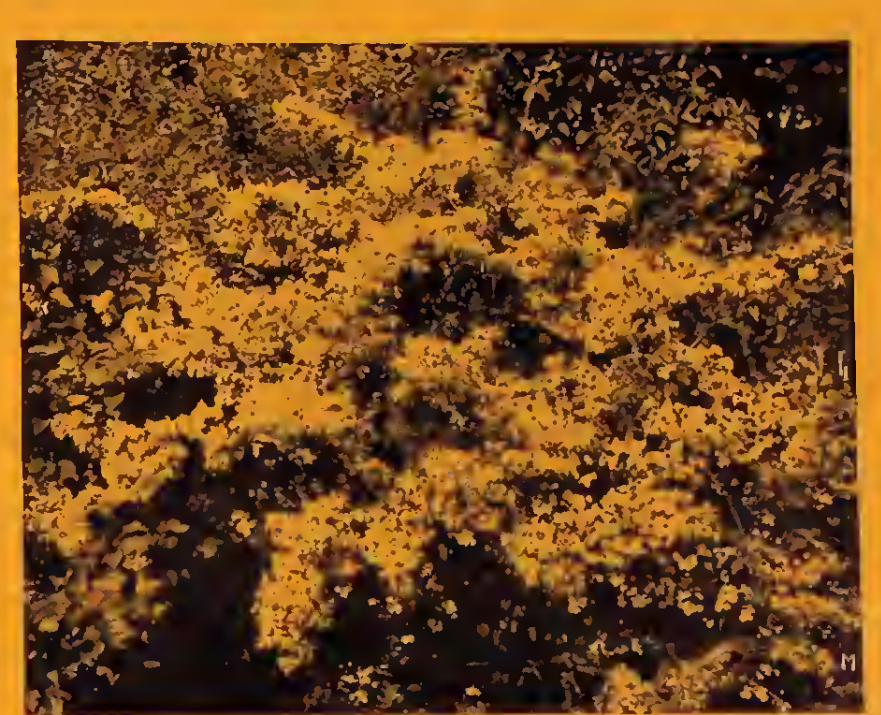

Kolkwitzia-Beauty Bush (Kolkwitzia amabilis)

Another recent Chinese introduction that bids fair
to prove one of the most popular of new shrubs. In

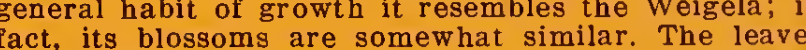
are medium size, highly interesting, and of an excellent green texture.
and its arching branches in May are studed their entire length with clear pink blossoms of delicate .

Philadelphus-Mock Orange (Philadelphus virginal)

This has been used, more or less, for several years
nd every season wins many new admirers. It is really double Mock Orange of unusual growth and wondmall roses, having attractive yellow centers. The plant is moderately vigorous but of good foliage. It lreauently carries its blossoms throughont the grow-
ing season-although not classed as an everbloomer. 4 to $5 \mathrm{ft}$
3
3 $\$ \$ 1.00$ each

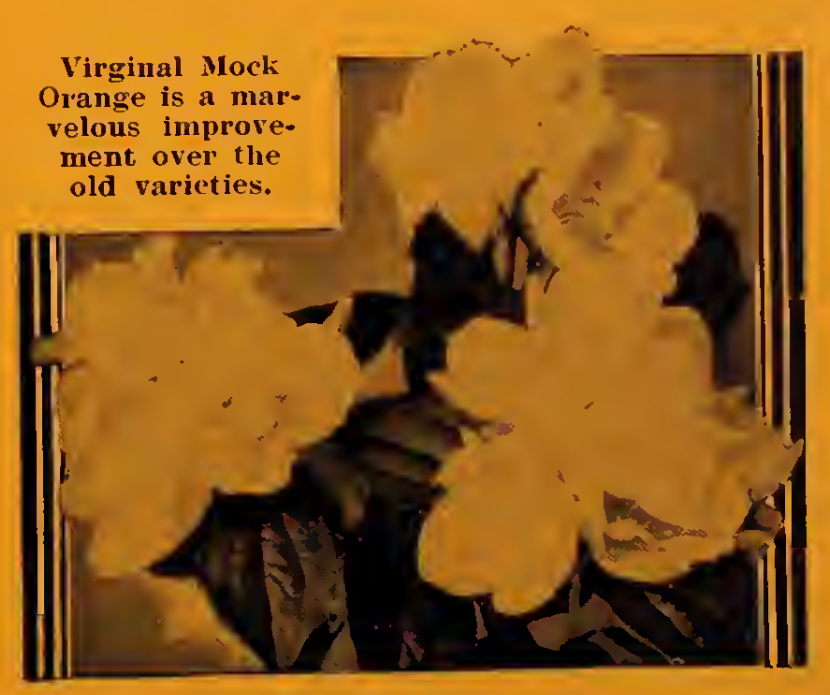




\section{More Trees and Shrubs of Special Merit}

\section{Korean Spirea}

(Spirea trichocarpa)

This is a more recent addition to the list of attractive planting shrubs, but already the indications are that in popularity for home grounds, it is destined to supplant the more familiar old-fashioned Bridal Wreath Spirea. This newer species grows from four to six feet in height, depending upon the quality of the soil in which it is planted, and forms a broad spreading, compact bush. Its flowers are clear white, with distinct marking in the center, and borne in large clusters that are often 3 to 5 inches across. The flower clusters are well distributed along the branches, forming a nuassive display of gorgeous white bloom. This variety is effective for planting about foundations.

2- year old plants.

$\$ 1.00$ each

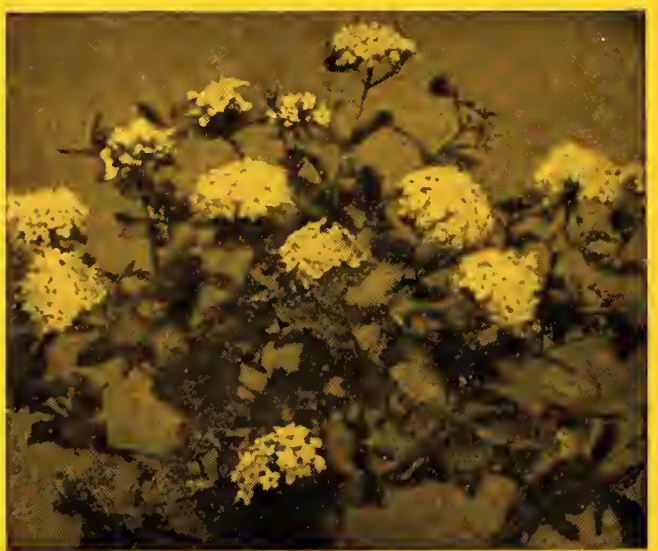

\section{Cut-Leaf Weeping White Birch}

(Betula pendula gracilis)

While this has long been a comparatively well-known tree and one that we have listed for several years, people often inquire if we have it. This happens because those who know

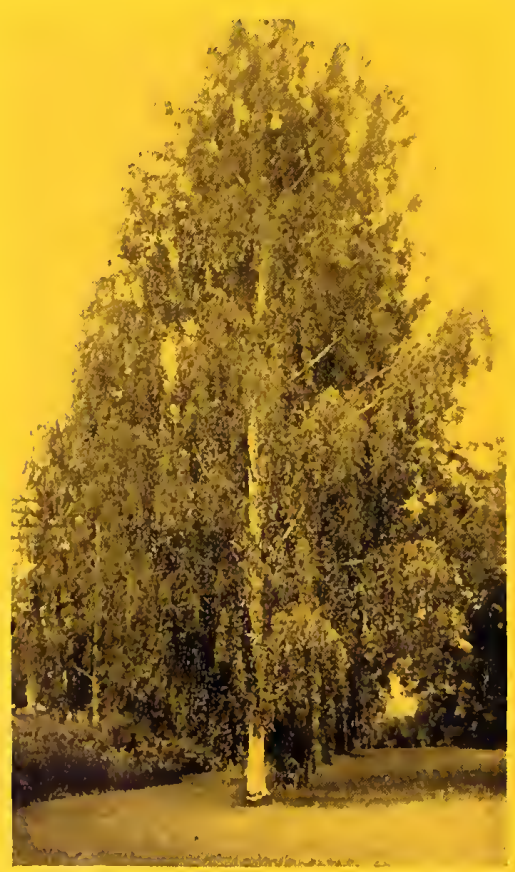
characteristics and beauty, know it is unusual and do not think to find it among ordinary listings of popular trees. It forms a pyramidal tree of moderately rapid growth, and as it grows older the younger branches become pendulous-drooping decidedly $\mathrm{t} o \mathrm{w}$ a $\mathrm{r}$ t $\mathrm{h} \mathrm{e}$ ground.

10 to $12 \mathrm{ft}$. trees, $\$ 4,00$ ea. 8 to $10 \mathrm{ft}$. trees, $\$ 3.50$ ea.

\section{American}

\section{Cranberry Bush} (Viburnum americanum)

An American shrub that is winning its way into favor and already being preferred by many to the more common European variety. It fills the need for a strong growing bush with scarlet berries, in large bunches.

3 to $4 \mathrm{ft}$. size...75c each 2 to $3 \mathrm{ft}$. size...50c each

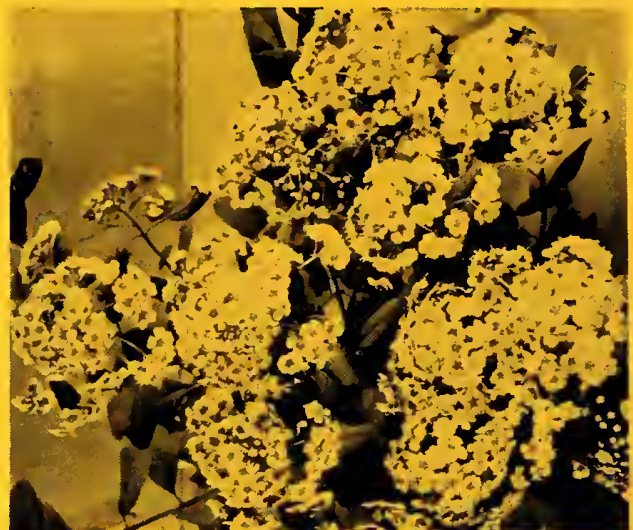

Fragrant Viburnum

\section{(Viburnum carlesi)}

ragrance that carries far on the soft spring air, is the distinct characteristic of this fairly new variety of shrub. This is rapidly making it one of the most , with a delicate shading of pink, borne lightful perfume that can be noticed even from afar.

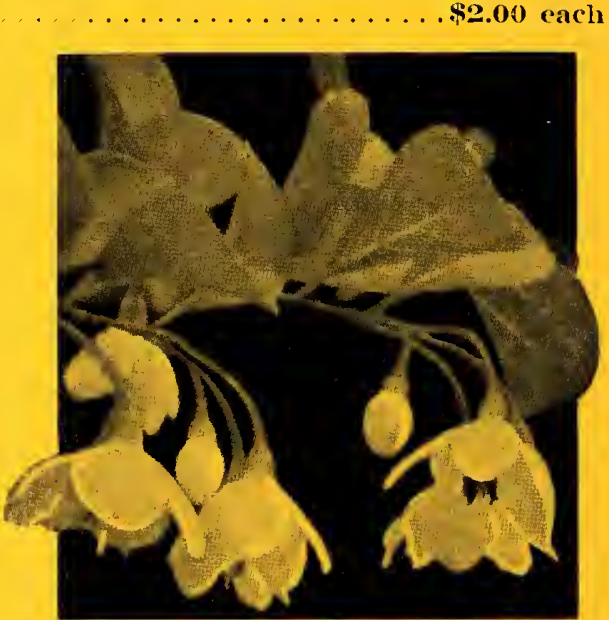

Japanese Snowbell

(Styrax japonica)

This is a very decorative shrub that should be far more generally used than it is. It grows into an unusually attractive bush, towering ten to twelve feet in height, with rich heavy foliage mass. It is most effective wherever planted either as a specimen or when used in mass formation for a background or screening shrubbery. Chief interest. however, centers in its unusual bloom. In its flowering season, during June and July, it is covered with a profuse display of pendent, bell-shaped, white blooms.

3 to $4 \mathrm{ft}$ size.........\$1.00 each 2 to 3 ft. size..............60 each

These plants are selected for their unusual year 'round beauty and general excellence. 


\section{CLIMBING - SHRUB and DWARF ROSES}

\section{CLIMBERS}

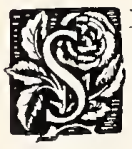

INGULAR beauty and pleasantness may be added to your house and your garden with the use of climbing roses. They can be put to many uses, not only as delightful ornaments. but also as a means to transform unattractive walls and corners.

No. 1, 2-yr. Plants, 50c each; 5 for \$2.25; 10 for \$\$.50)

Imerican Pill:ur. Flowers large and single; range from 2 to 3 inches in width. Brilliant carmine-rose with cream variations and yellow stamens at center; produced on immense clusters; being very showy and attracstrong, rapid growth, healthy foliage and a wealth of flowers.

Alidi Lovett. This is a splendid, large-flowering, shell-pink climber. Lighter in shade than Mary Wallace, rapid growing, of unusual good foliage.

Ress Lovett. L a $r$ ge flowers of a bright, light crimson, blooming later than Climbing American Beauty, and in some cases is preferred to that variety.

Christine Wright. A delightful clear, deep pink with glossy, healthy deep pink with glossy
foliage. One of the best.

Climbina Imeriean Beanty. This is a wonderful new rose resembling its namesake in character and size of bloom. In color it is a deep
nink, not so dark as the busls finli,

Dorotly Perkins. There are so many roses better that we are discontinuing this variety.

1)r.W. V:u Fleet. Blossoms extra large resembling the tender $\mathrm{Hy}-$ brid Tea roses in shape and size. Its strong stems are 12 to 18 for cutting. In color a delicate for cutting. In color a delicate blown to flesh white.

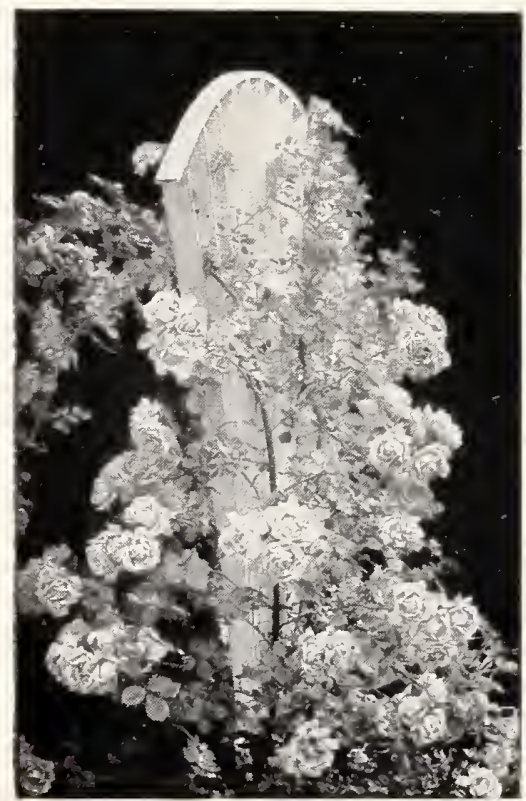

PAUL'S SCARLET CLIMBER.
Freelsa. (IRed Dorothy Perkins.) This variety is one of the best. PRed Dorothy Perkinx.) This variety is one of the color, borne in great clusters from almost every bud.

Gardenia. This is a Wichuraiana or Memorial Rose. Very desirable for covering graves, rock walls or stumps. Color in bud a pleasing bright yellow, opening double cream color.

Miry Lovett. An ideal white rose, blossoms as large as Hybrid Perpetuals. Perhaps the best of its type in color.

Mary Wallace. Large bright double pink flowers illumined with gold. Plant vigorous and has superb foliage.

Paul's Scarlet. This new rose is the finest red climber introduced. Vivid scarlet, shaded crimson, semi-double, retain color till they fall. Vigorous grower.

Roserie. This bears large clusters of fine blossoms about the shade of Dorothy Perkins which we discontinued. It is really a pink "Thousand Beauties" and is very popular.

ilver Morn. Another new rose that has made a name for itself. Flowers cup-shaped and largest of all the climbers. Semidouble and pure white with beautiful yellow stamens in center.

\section{BABY OR DWARF ROSES}

These dwarf or baby roses prove very attractive where continuous bloom is wanted throughout the summer. The small roses are borne in clusters and seldom is the plant without some bloom. The average height is eighteen to twenty-foux shrubs or even mixed with per everoen al the edse of lend a continuity of color not obtained with other plants. We offer these in two-year-old plants in pink, red and orange shades.

Grua Tescluendort. The most popular of the bright reds, in continuous bloom and perhaps best of the dependable red variety.

Ellen Ponlseu. This is soft pink and unusually prolifie in bloom. The small flowers are borne in clusters and the plant is vigorous and healthy.

Goldeu silmon. Has large clusters of reddish orange buds of striking color. The bush is compact and is fine for mass effect ittracts attention and admiration.

No. 1, 2-yr. Plants, 50 cents each; 5 for for $\$ 2.25 ; 10$ for $\$ 4.50$

\section{SHRUB ROSES}

Hnwnis. Commonly called the "Golden Rose of China". Without doubt this is the finest "shrub" rose known. Blooms in May and produces a mass of single yellow, cup-shaped flowers that cover the arching branches to the very tips. The foliage which is finely cut is more attractive than most shrubs being very deep green, thickly studding the canes. mass effects. Use as No. 1, 2-yr. Plants, 50 cents each; if for $\$ 2.25 ; 10$ for $\$ 4.50$

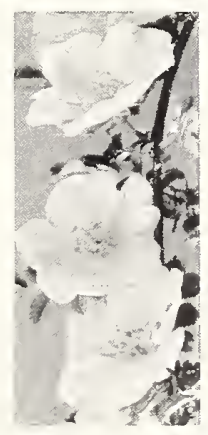

Hugonis Rose. let ux luelp you with with vour landsape platuning. 'This

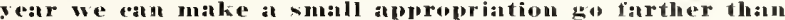
ever before. Why wait? 


\section{BUSH ROSES -}

Hybrid Teas (H. T.) are the everblooming varietics Hybrid Perpctuals (H. P.) are the monthly varieties

P'RICES: All Roses Listed on this Page Only.

Yo. 1 - Ycar-Old Plants, 50 Cents Eaclr; 5 for $\$ 2.25$; 10 for $\$ 4.50$.

IBeIt. Cpricliard. H. T. One of the finest new Roses with copper-red buds opening into semi-double salmon-pink blooms. It is a good bloomer and one of the outstanding new varieties.

Druschli-Snow aneen or White American Benuty. H. P. This is a wonderful in growth, it produces great masses of large pure white hovers in June

Muchess of Wellington. H. T. This is an intense saffron-yellow stained rich crimson. Like all yellows is just a bit tender but well worth the few minutes necessary for winter protection.

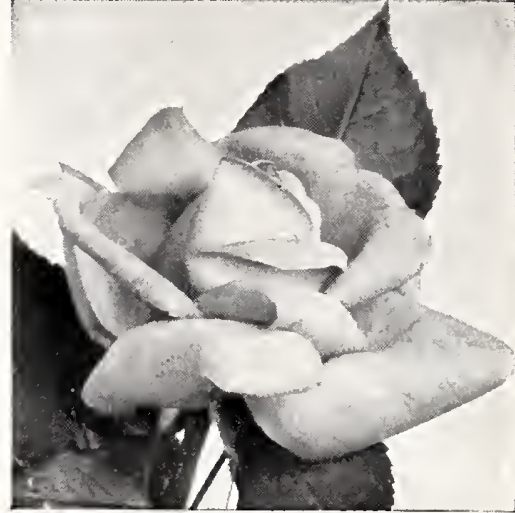

BETTY UPFICHARD l'racis soott key. H. T. An unusually fine, wonderfully shaped, very double Rose of a brilliant crimson color. Very fragrant and does well in dry season

General Jacuneminot. H. T. Affectionately called "General Jack" and truly a veteran of many years. It is known and wanted by every one and notwithstanding the many new varieties, this grand old brilliant scarlet crimson rose finds a place in every rose bed.

feneral Mac Arthur. H. T. A fiery red, magnificent in color. Very free blooming. One of the best.

Gruxs nu Teplitz. H. T. M e d i u m d o u b le blooms of brilliant crimson. Makes small plants but blooms all season very freely.

Joukheer J. I. Moek. H. T. Clear pink with outer petals a silvery white. Called a giant LaFrance. One of the best.

Is. A. Victoria. H. T. Well formed creamy colored buds that open into white fowers. Free blooming and hardy.

killaruey Irilliant. H. T. This is an old favorite of splendid characteristics. Color is a bright deep pink and while a new rose it is extensively planted.

Lady Hillinglon. H. T. Perhaps the inost popular yellow, producing flowers of apri cot yellow color. Very fragrant and free fowering. Protect in winter.

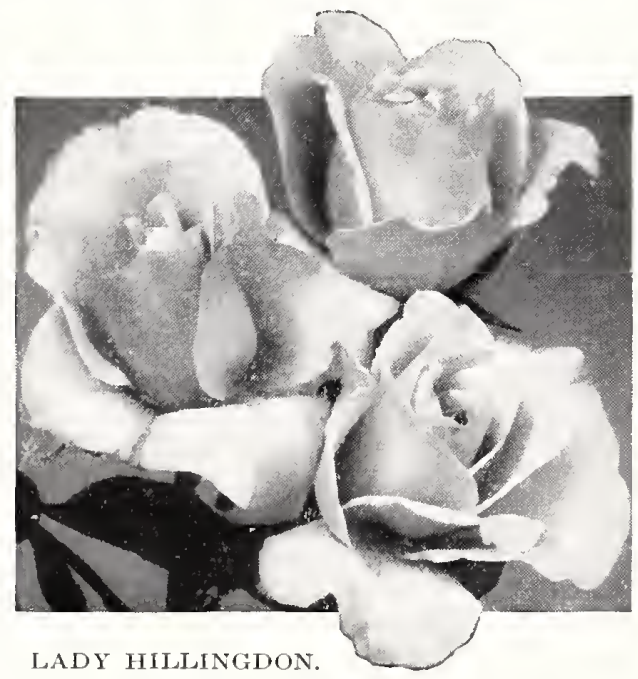

PEAT MOSS

For lroses and Other Plants

We oncer a large bale of Gramulated

Peat lloxs at \$4.00 per bale. 5 billes at $\$ 3.75$ ver bale.
Madam Imutertly. H. 'T. 'The best Rose of the Ophelia type. Color is a bight light pinli shaded with gold.

Iladam Edon:md Iferiot. H, T. Very striking coral red, and as they open, shade orange and copper. One of the best late and vigorous.

nume. Nuert Barbier. H. P. While a Hybrid Perpetual it blooms without ceasing from spring to fall with lalge Camellia-lilie flowers of cream and pinkish yellow.

Mrs. Anrou Ward. H. T. Makes a low bushy plant with hollylilie leaves. The blooms might be described as tawny golden pink. Agreeable fragrance.

Irs. Clnarles Bell. H. T. This might be called a salmon Radi ance, having all the good qualities of Radiance and Red Radiance. Blossoms of a clear shade of salmon pinli turning to pearly pink. Fine addition.

Irs. Johu Laing. H. P. An erect growing healthy plant pioducing numerous cup-shaped, soft pink, fragrant b los s o m thioughout the summer. One of the finest of Hyblid Perpetuals.

Panl Neyron. H. P. No doubt of its being the most popular hardy perpetual grown. Because of its vigor of busli and pleasing color, large size and comparative freedom from thorns, there is an unprecedented demand for it always.

IRadiauce (Pink). H. T. This is the easiest grown and most reliable Hybrid Tea Rose. It has no serious faults and is the best variety for this section. Brilliant rose-pink buds opening into well-formed blooms with silver tints on reverse of the petals. Blossoms are fragrant and plant makes vigorous growth. Our most outstanding reliable rose regardless of color.

Red IRalianee. H. T. Read the description of Radiance and apply the good things said of it to this variety, except the color, which is a deep rose red. Blooms until frost and is the best all alound red rose in existence.

Sonv, de Claulins Pernet. H. T. This is a new rose and after a few years test proves to be the best goldell-yellow rose of toay. It is charming in bud, and the flover in opening retains the intense color. Foliage very good and quite a free bloomer.

willowmere. $H$. $T$. This Rose is being used to supplant Los Angeles, which does not always succeed. It has long pointed buds of brilliant pink with golden tinge. Makes a vigorous plant of upright growth and is a continuous bloomer.

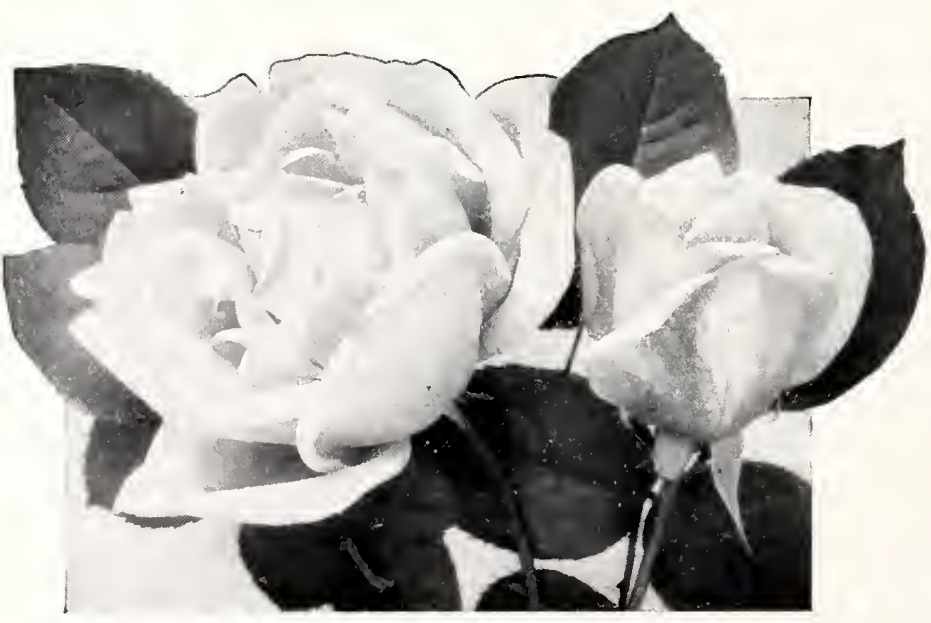

RADIANCE ROSE.

A rose garden is a joy all summer, especially with Hillenmeyer roses. 


\section{DE LUXE ROSES -}

This small selected assortment contains the very best varieties, proven worthwhile in the hundreds of tested kinds

l'rices for these Extra Fine lioses on this Page. Z-Year-Old Plants \$1.00 Each; 6 for \$5.00.

(Any Selection.)

Here is a list of the finest Poses obtainable. They are not norelties but have been tested and have proved superior because of their good qualities. Plant these if you want magnificent flowers.

Eroile Ie Hollande. It is said that this is the best and most populal red Hybrid Tea in the world. Its gigantic flowers of velvety crimson color hold up renarkably well, getting lighter in shade instead of "bluing" with age. It thrives everwhere and produces a fine lot of blooms throughout the season.

Iand Marmaret stewirt. A vigorous erect grower producing in mense copper-orange buds, opening to bright golden vellow. Blossoms of Wolnderful sle

Rev. F. Pare Robert. Described as a glorified Duchess of Wellington with more petals, better shape, and of a deeper, richer color. Coprer red buds witl reddish buff outside, making a most attractive bloom.

'Talisman. Another new and outstanding variety recently introduced but frequently called for. It has brilliant orange-red buds opening to large fragrant blooms of golden yellow. Admired by every one and should prove very popular.

Ir.s. Henry Morse. The blooms are a bright pink with silvery shadings and are incessantly produced on long branches. One specialist describes it as having all the good qualities of Mme. Testout, . L. Mock and Lady Ashtown. Has a larger and more artistic bud pink roses and will, no doubt, prove very popular.

Dime Edith Helen. It is well described as being the largest and most perfectly shaped Pink Hybrid Tea Rose known. Pinom abundantly on strong stems. Everyone srong it hns been attracted by it. Said to be the most fraglant of pinli luses.

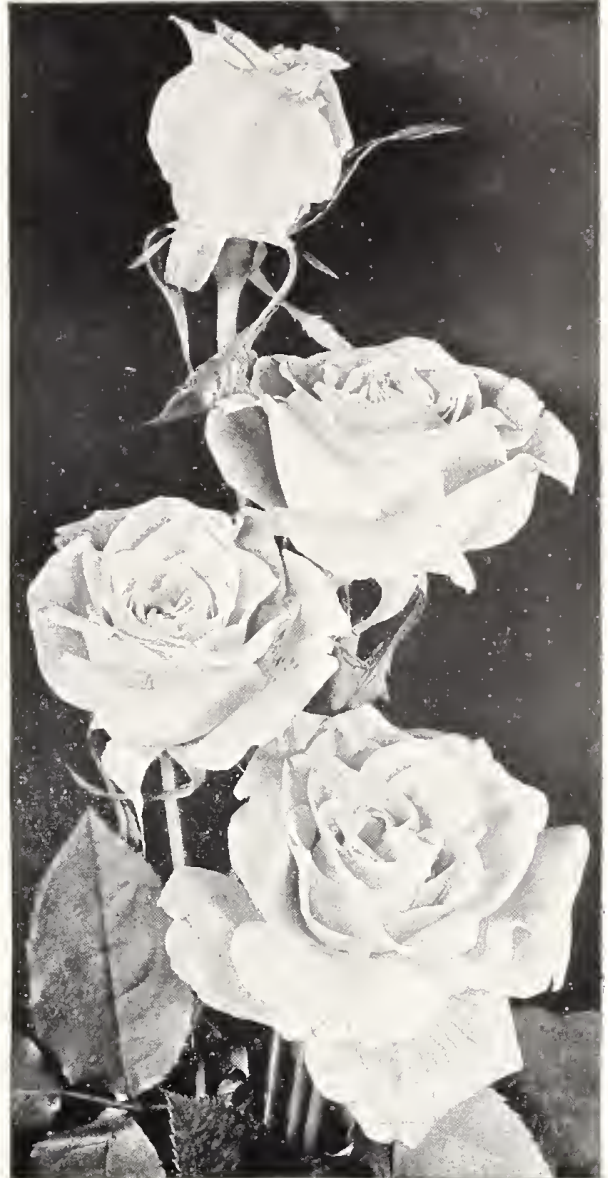

Talisman, a delightful newcomer.

\section{HOW TO PLANT AND CARE FOR ROSES}

Foses like good soil and half the battle is won by preparing the beds with deep spading and adding manures or suitable fertilizers. If the location is not well drained the addition of sand and Peat Moss will be of great value. Poses are heavy feeders.

The illustration below shows the correct method of pruning at planting time. As Poses are grafted

in the nursery. The mound of soil indicated is suggested for winter protection. However, if planting is done in late spring or in dry weather, soil thrown over the tops until the roots become active is also very beneficial. If covering is done at time of transplanting, leave the mound for a week or ten days and then remove, but when plants are covered for winter. protection, uncovel on ly after dan $r$ of severe weather is past.

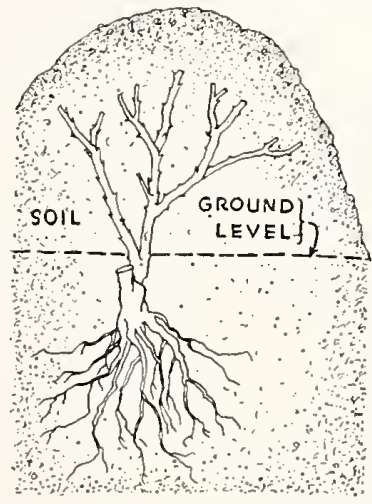

How to plant new Roses. (See text.) on other stock, set deeper than it stood

I'RCNING OF ROSES-Bush roses should be pruned every year and while not so severe as at transplant ing time, it is much better to remove the surplus growth to promote new vigorous shoots which will produce lal'gel flowers. Prune only in the spring jus as the new gl'owth starts, but prune every yeal and keep the bushes in balance. Pick off old flowers, and in cutting, leave a slort spur of two bud length from which new shoots will come.

'The pruning of Climbinm roses differs in that it should be done immediately after blooming. Take out the old canes. This will encourage the growth of young vigorous ones for the next year's bloom. Moderate pruning every year is a
the spring unless of necessity.

SPIRAYNG-Roses are all more or less troubled with mildew, black spot and lear-eating insects. Ther ale a lot of ready-made preparations on the marke for these troubles but one that can be made locally and applied with a small dusting gun or even shaken from a bag consists of one part Arsenate of Lead, one part Tobacco Dust and nine parts of Dusting Sulphur. Nicotine Sulphate is recommended for Aphis.

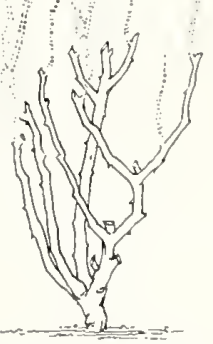

How to prune old Roses. (See text.) 


\section{HEDGES}

Living walls of green, beautiful the year round. A fence you never have to paint

W

HETHER it is used as a living wall of gleen, neatly trimmed and kept witlin bordel's, or as a free growing row of shrubs which screen out unsightly views, there is nothing quite so satisfactory as a hedge.

Where little space is available, the hedge makes an ideal boundary planting. The liedge is decorative the year around and will add mucl to your lawn.

Our hedge plants give splendid results. Here you will find a variety of plants suited for any purpose to which you wish them used.

\section{IOIIET IPICHS IN YHARS}

Now is the tiune to put in your Hedging and save.

\section{Amoor River Privet, South}

I,ismstrum simense. Semi-evergreen hedge that grows quickly. Occasionally it freezes to the crown in a severe winter, but alvays comes back witl renewed vigor.

PRICIS:

$18-2+$ inclues $\ldots . . . . \$ 150 \$ 400 \$ 8.00$

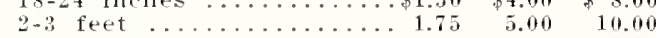

\section{California Privet}

Licustrum ovalifolium. A semi-evergreen hedge with thich, shining leathery leaves, that glows very rapidly, can be pruned into any formal effect and planted by everyone needing a quick hedge without much expense and trouble. It blossoms in spring, the fragrant white flowers being noticeable for some distance. In planting it is a good idea to cut away practically all the tops of the smaller plants in ordel to get a bushy hedge. We have quantities of this desirable variety.

PIR I CIS:

$10 \quad 50 \quad 100 \quad 1000$

$12-18$ inches, 2 or

mole branches...\$.75 \$2.50\$5.00\$40.00

$8-24$ inches, 3 or

more branches... $1.00 \quad 3.00 \quad 6.00 \quad 50.00$

$2-3$ feet . . . . . $1.25 \quad 4.00 \quad 8.00 \quad 65.00$

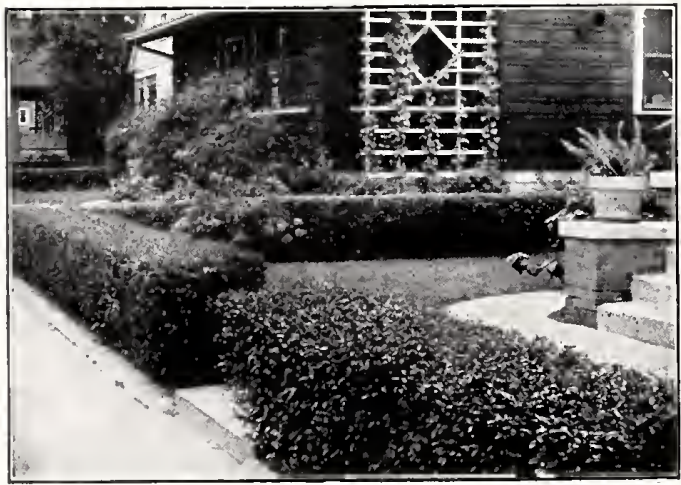

Amoor Privet makes an excellent hardy hedge.

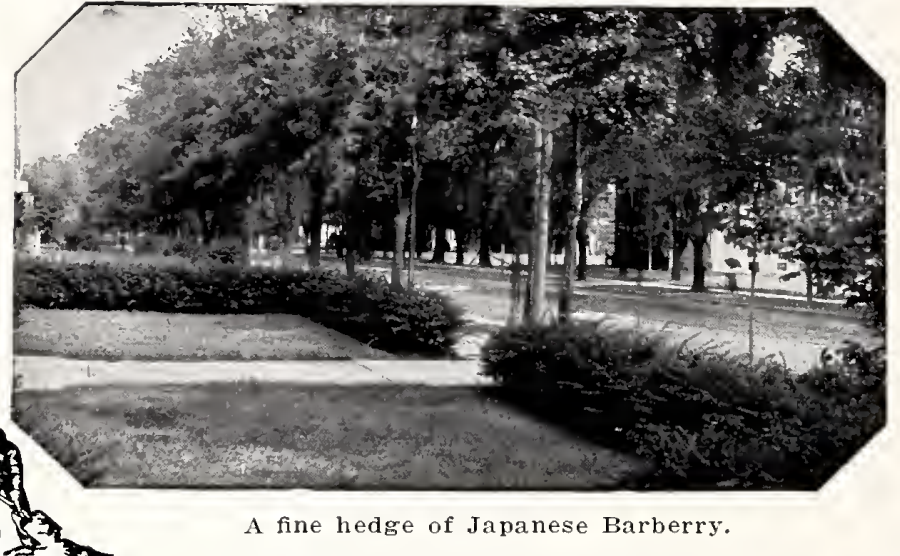

Fragrant Bush Honeysuckle

Lonicera fragrantissima. This is the very best tall growing hedge ever offered. It is almost evergreen, holding its foliage in mild winters all season. It blooms in March, having a most fragrant blossom. Makes a strong, bushy, dense riant and normally grows into a hedge 6 to 12 feet. Requires rery little pruning and will grow anywhere. Best hedge we know for screening purposes.

\section{PIR I CES :}

$10 \quad 50 \quad 100$

$18-21$ inches................. $\$ 2.50 \$ 7.50 \$ 15.00$ $2-3$ feet...............................

\section{Thunberġ's Barberry}

Berberis thunbera. This Japanese shrub is being used more and mole as a hedge. Not as quick in growth as Privet, but absolutely hardy. Its small, glossy leaves are out early in spring, succeeded by yellow flowers. The foliage turns a bright red in the fall, and this is followed by red berl.ies. It is a graceful, drooping shrub, making an elegant lies. It is a graceful, diooping shrub, making an elegant raliety for hiding foung in the corners by steps, ete., also does well in shady places. maining fresl until spling and for its dazzling fall color ing. Our heavier bushy plants will make immediate effect planted.

PIRICRS:

$12-15$ inches

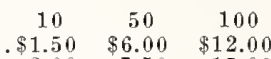

$\begin{array}{rrr}\$ 1.50 & \$ 6.00 & \$ 12.00 \\ 2.00 & 7.50 & 15.00\end{array}$

\section{OTHER HEDGES}

rany other plants may be used for hedges.

We can quote you on:

spireas Osage orange Ibolium Privet

Abelia Althaea Boxwood

Hydrangeas Amoor Privet North liegel's Privet, Eite.

Write for prices if interested.

\section{It is Easy to Grow Hedges}

I'I I T I I R. If you wish a thick hedge, Privets should be planted six to ten inches apart and Barberry, twelve to fifteen inches. At planting, tops should be cut bacli to four to six inches above the ground so the branches will be encouraged from the

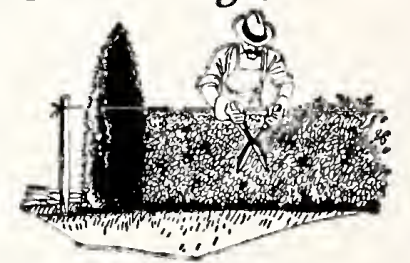

a mulch, is suggested for fall-planted hedges.

IPINING. Each spiting the hedge can be trimmed back to the desiled height and width. Frequent trimming, during the early summer, will malie the hedge grow dense. But avoid further pruning after Septem-
ber fifteenth as the young tender shoots that would be encouraged might be killed by winter. In pruning trim both the sides and the top, or the hedge will grow wider at the top and become open at the bottom.

Hedges of flowering shrubs never bloom well when "boxed," so if you want their blossoms you must permit them to develop naturally and prune them only by occasionally touching up their ragged growth. 


\section{ORNAMENTAL VINES}

\section{Climbing and Trailing}

$\mathrm{T}$ HERE is something about vines that gives an indescribable charm to wherever they are ing touch of beauty to a home and serve to cover walls that otherwise would look quite bare. If you use them judiciously you will find them valuable in the plan to make your home very attractive.

BITEERSWEET. Celantrus seandem. This is our native variety that is so unusually attractive,
because of berries in the fall and early winter. Vigorous. Price-40 cents each; 5 for $\$ 1.75$.

BOSTOX IVY. Impelopsis veitchi. The best of the self elinging vines. Leaves are deep and very dense, covering any object completely. Foliage orous when established. Price-40 cents each; 5 for $\$ 1.75$.

CLFMATIS jackmani. This is the most popular Chinese clematis. Has large purple flowers. Exquisite when it can be grown. 75 cents each; 5

Clematis paniculata. The small white "star" variety that blooms profusely, easy to establish Fragrant. Prices-40 cents each; 5 for $\$ 1.75$.

ENGLISI IVY. Hedera helix. The most popular evergreen vine having large deep green and in shady and cool places. Can be sheared into in shady and cool places. Can be sheared into 40 cents each; 5 for $\$ 1.75$.

HONEYSUCKLE, Japan or Halls. (Lonicera jap. halliana). An evergreen twining vine that is so tinuously, is fragrant and very easy to establish. tinuously, is fragrant and very easy to establish.
Price-40 cents each; 5 for $\$ 1.75$.

Honeysurkle, searlet. (Lonicera sempervirens). Has attractive trumpet shaped flowers of cents each.

lí Uzec. Puerariat thunberwiana. The most rapid growing twining vine known today. It is marvelous how it will cover objects. Belongs to the pea

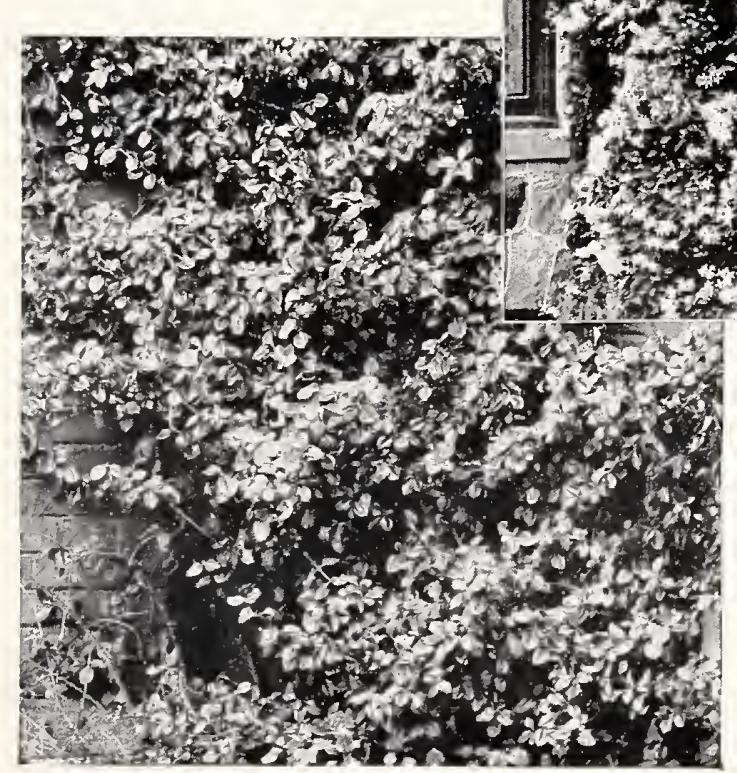

Bigleaf Winterereeper climbing on brick wall.

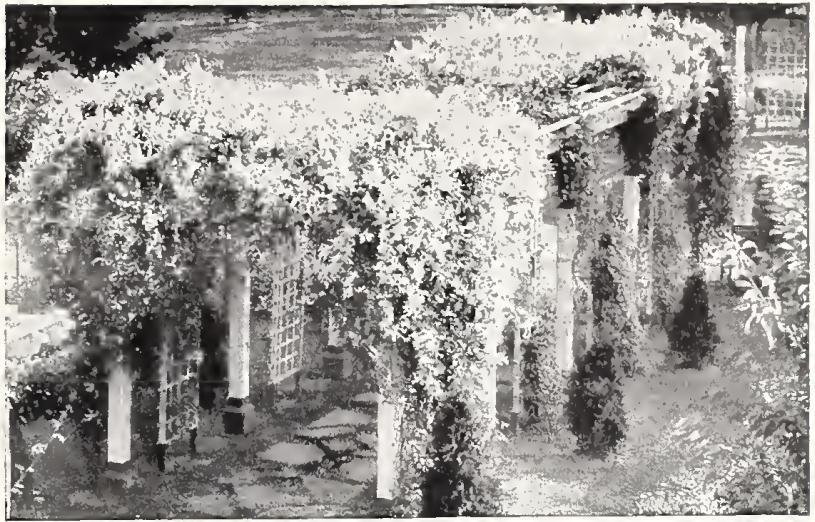

Silver Tace Vine is unexcelled for graceful twining effects.

family and the foliage is dark green. Large flowers are Very sweet scented and purple in color. Irice-40 cents

SILVER LACE VINE. Polyanmm anberti. A new quick growing twining vine with small attractive foliage. The nowers are very small and lacy and when the Blooms over a very long period, from August to frost. Price-75 cents each; 5 ior $\$ 3.00$.

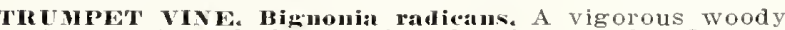
vine; native of this section, bearing scarlet flowers, followed by long pods. It is easy to establish and grows or rustic work. Price-40 cents each; 5 for $\$ 1.75$.

VIrGINI CREETER. Ampelopsis emgelmammi. This is our five leaved ivy that is so valuable for covering walls, fences, etc. Will grow anywhere and colors brilliantly in the fall. Price-40 cents each; 5 for $\$ 1.75$.

WINTERCREAPLR. Euonsmus radicans. A slow growing vine that adheres to the masonry and remains deep green all winter. 40 cents.

MIGLEAF WINTER CREEPER, EHonymus ralieans vesetux. Another evergreen clinging vine of more robust habit, perfectly hardy and especially valued because of the
profusion of red berries that hang on profusion of red berries that hang on each; 5 for $\$ 1.75$.

HRONZE WINTJRCREEPIR, GUOMYMU, coloratus. This is a comparatively new vine growing more rapidly than orous shoots, family. It has long vig sharply pointed leaves. Clings exceptionally well and makes an artistic effect on a bare wall or chimney. Turns a rich bronze during the winter months. 40 cents each. 5 for $\$ 1.75$.

WISTERIA CHINENSIS. Chimese Wisteria. A rampant clinging vine that has the robust vigor of a wild grape and the matchless beauty of a rare clusters.

There is so much complaint of Wisteria not blooming that we are offering this year plants that are grafted from blooming wood. This insures only in two year old plants. Price-

Clematis paniculata. 5 cents each. 5 for $\$ 3.00$.

\section{Vines for Special Uses}

Cover Toll of Peracola

Kudzu Vine

Wisteria

Silver Lace Vine

For firaceful Twining wirects on sides and Top of Pergada Bittersweet

Clematis in variety

For solid sercen Effocts

Virginia Creeper

English Ivy

Boston IVy

Trumpet Vine

If your home is small, we are just as anxious to landscape it as if it were big 


\section{Hillenmeyer's HARDY PERENNIALS}

Flowers the Season Through Unrivaled in Color and Beauty

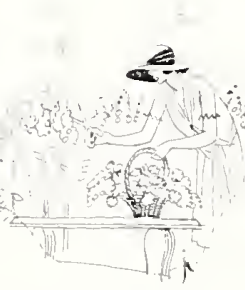
lection there is listed here a wide variety of those dependable, hardy plants, that once established, assule vou of a succession of blossom without the constant trouble of replanting.

\section{Anchusa}

We offer the deep blue shade of this excellent perennial. It grows four to five feet, and sometimes needs staking. Blooms in May and the giant stalks are a mass of pretty blue flowers. For the baclicound of a hardy border this is indispens able where blue color is wanted. 4 -6 feet.

\section{Anemone-Windflower}

Valuable plants for massing, profuse in bloom and gain strenth and beauty each year. Plant in semi-shaded locations. Usually a show from Sepr until November for cut flowers.

Uneen Charlotre. Abundant semi-double flowers of silvely pink. Glow two to three feet. 40 e each.

Whilwinl. An excellent double white variety. Very hardy Grows two to three fert. foc each.

\section{Aquilegia-Columbine}

1.on. spmr. As a cutting flower this type of Colum bine is the daintiest of spring flowers. Will grow in semi-shade ilthough they prefer sunny lo mions. Period of bloom from spring to early fur stock is of selected long spur hybrids mixed.

coerulear (Roeky Mountain Hlue Columbine). This variety is well suited for Rocliery planting, semi-shady and shady locations. Not so dainty is the formel gloul but will grow anywhere and

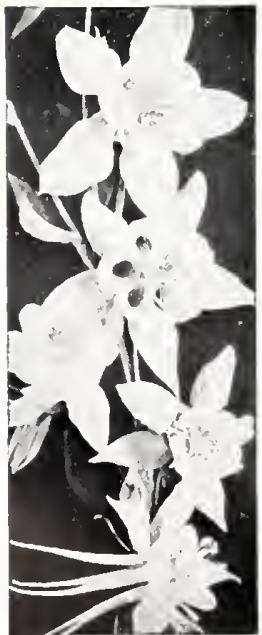

AQUILECIA

\section{Astilbe-Spirea}

An unusually attractive plant with spilies of showy flowers in May and June. Prefer half shaded and moist locations in good soil. Height three to four feet. Can furnisl in Pinl and White. Price, 40 cents each.

Asters-Hardy or Michaelmas Daisy

A native wild flower in which many implovements have been made and hybrid forms produced by clossing. They should be divided every three or four years, and make attractive fall flowers. 'The height varies from three to four feet. We offer them in Blue and Pink.
ERENNIALS are be-
com ing more and more popular w it $\mathrm{h}$ the increase in gardening. No home grounds are now completely planted without a border of these continuously blooming plants. If you plan carefully you can have flowers all year. For your se-

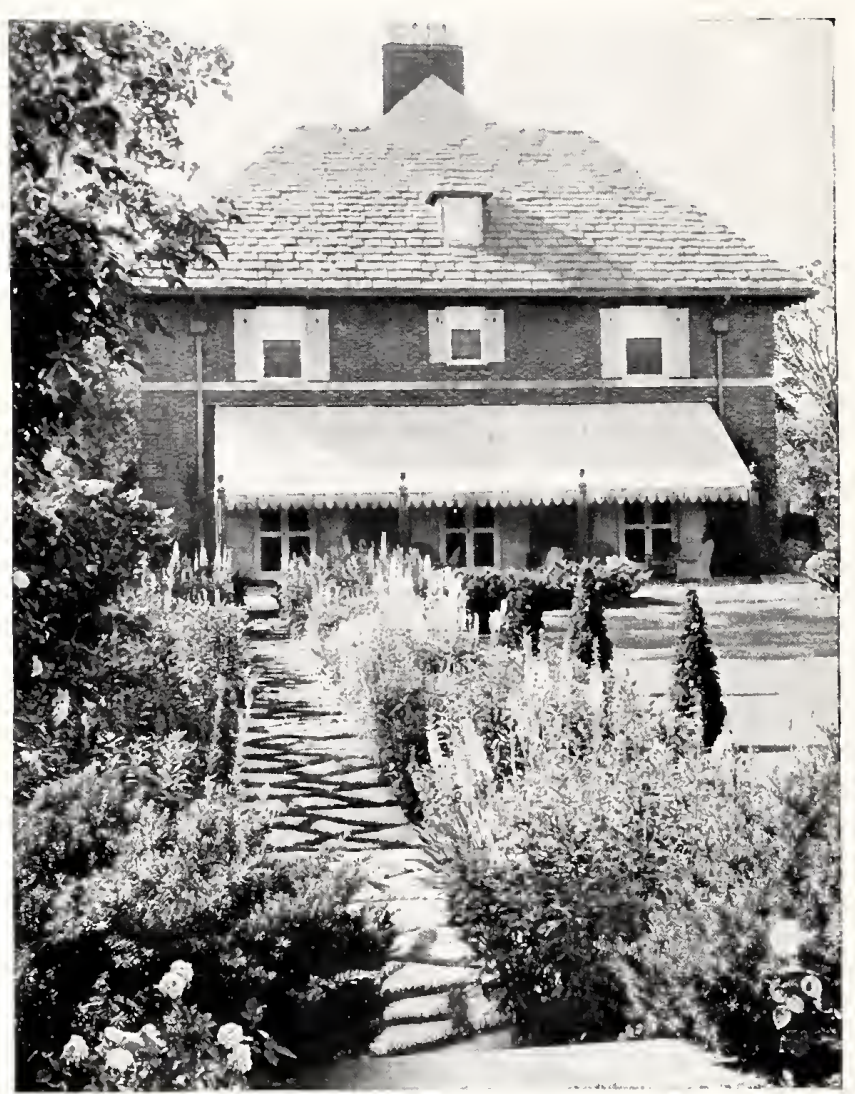

Hardy flowers bring life, gayety, cheer and color to the out door living room. A border such as this is a great possession.

\section{Baby's Breath}

Gspopliala panienlata. $2 \frac{1 / 2}{2}$ to 3 feet. May-June. Tiny white flowers with slight pink coloring. Almost a mis of feathery bloom. Attractive and useful to "soften" stiff-stem flowers in bouquets and desirable for drying for similar use in winter.

(ispsophila paniculata flore-plemo (Double baly:s Breath). Ilasses of minute white blossoms, similar to the above. eveept double. These are grafted plants. Price. 40 ceut. each.

\section{Baptisia - False Indigo}

Darls blue pea-shaped or Lupine-like flower's, blossoming in May and June. Makes vigorous foliage and can be used in front of shrubbery borders or wall garden. Grows two to three feet.

\section{Beard Tongue-Pentstemon}

ve offer a variety called "Sensation" It grows twentyfour to thirty inches high, every branch being a spike four to lilac. As a border plant it compares with Petunias or Plilox.

\section{Bleeding Heart}

Wicentra spectabilis. A familiar hardy perennial with heart shaped, rose colored flowers in droping spikes. Prefers sions in May. An old favorite. Special Price, 40 cents each

PRICES ON PRIRENNIALA

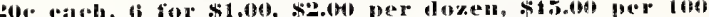
(11 40e varieties- 5 ior $\$ 1.75$ )
BLEEDING HEART

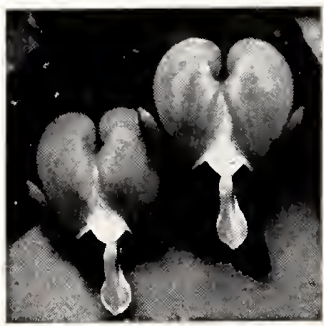

See page 38 for suggestions on how to arrange perennials 
Canterbury Bell

Camp:unla. Another garden farorite. Blossoms borne on long stems in many shades and colors. Partial shade and rich soll produce the better blossoins. This is a biennial, June. $2 \frac{1 / 2}{2}$ to 3 feet.

\section{Carnations}

These are the haldy border Camations. We offer these in mixed colors. The flowels are medium sized and have all the characteristics of the varieties grown under glass. 1 to 2 feet. June to September.

\section{Chrysanthemums}

These are hardy and most attractive in September and October. In planting these try to group them, as some seasons it may be necessary to save from early frost by covering. Height, 2 to 3 feet. The flowers are very attractive, borne in large quantities Colors: White. IRel. Pink. Yellow.

\section{Cone Flower}

Bulbcelia purpurea (Giamt l'urple). Pecul iar reddish purple flower with large round cone shaped center. Blooms continuously troun Tune to September.

\section{Coreopsis}

A beautiful yellow flower, desirable for cutting or for border. After blooming the seed may be cut away and a good secondary blossoming will follow all
through the summer. Height, 2 to 3 feet. i)'alceful. June to August.

\section{Delphinium-Larkspur}

lBollalomna (Liplit Blue). The praises of this variety have been sung by every of the hardy border. Light tur guoise blue nowers are borne in spikes. the first coming in June. These may be cut away and young growth will star rom the crown, producing blossoms al summer. Height, a to 4 feet. Mulen light

Hellamosnu (Darle Bluc). This is an improved darli blue with all the other char acteristics of the preceding. 3 feet. June to September.

Funlish Hybrias. These are taller growing being 4 to 5 feet and in all shades of light and dark blue. June to September.

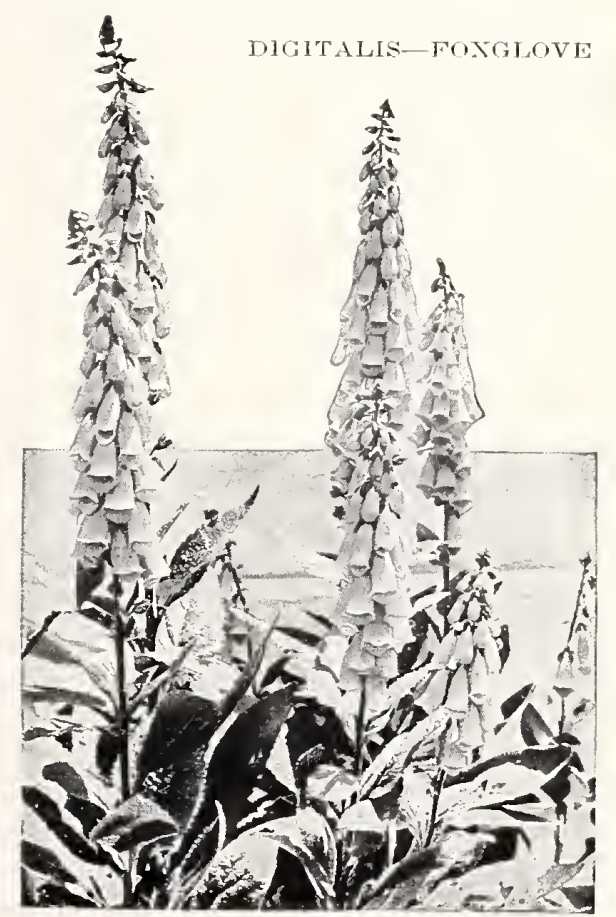

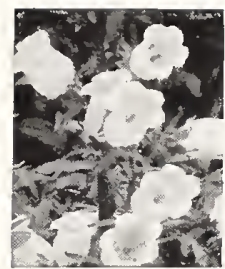

CANTERBUPY FELI.
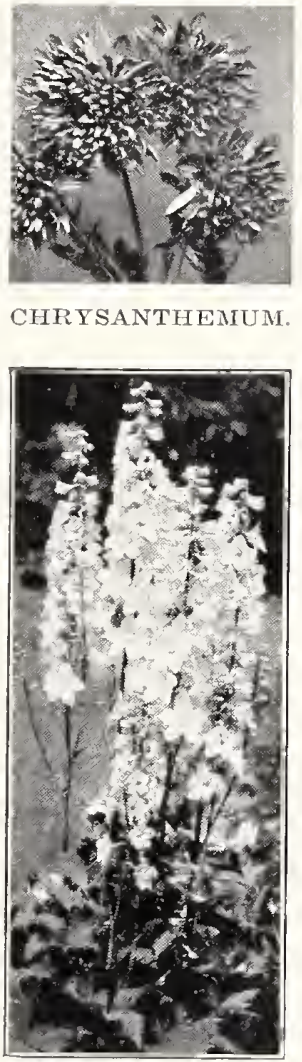

DELPHINIUNI

LARISPUR.
CHRYSANTHEMUM

Evening Primrose-Oenothera

romming. Is the favorite, growing two feet. blooming June through July, making a stoeky large leave a sunny positionor in the rockers.

\section{Flax-Linum}

nother desirable plant for the border or rockery, growing about two feet, with light craceful foliage. Blooms a good part of the summer. We offer the blue variety only.

Foxglove-Digitalis

This biennial is an old garden favorite. The flowers are borne on long stems ( 3 to 4 feet), and during their period of blossom are the most attractive thing in a border. These plants are not offered as to color. but are mixed seed from best plants They are, ordinarily, very easy to grow,

Gaillardia-Blanket Flower

IVill grow anywhere, bearing large quantities of yellow flowers flecked and marked with crimson and brown. Starting in June, there are blossoms all sumthe valued for cutting. 2 to 3 feet.

\section{Geum}

plant not lialf appreciated, malking an excellent border variety with blossoms of fiery red bloom intermittently all summer.

Hardy Candytuft - Iberis

A very dwarf plant 8 to 10 inches with evergreen foliage which is completely bidden by the mass of blooms in early spring. One of the best rockery or edging plants.

\section{Hardy Scabiosa}

Fine border plants preferring well drained locations. Excellent for cut flowers. Last long when cut and are of a pleasing trventy-four inches and bloons from June to September.

\section{Hibiscus-Mallow Marvels}

Larger and more brilliant than the old forms. Plants frequently grow five feet and during July and August produce flowers 8 and 10 inches a c ros s, especially if
given water. We can furnish in white, light and deep pink and red.

Hollyhocks

Evelyone knows them-with their long spilies of multi-colored flowers, borne in profusion as they are, there is no wonder they are so largely used. Flooming in June and July, so absolutely hardy that they will talke fuly, so absolutely

\section{Giant Reed}

Inudo don:Ix. This varjety grows to a height of of 12 to 15 feet, and is especially desirable fol background, the central feature of a bed planted with grasses, or to screen undesirable outlooks. Its long drooping bright narrow green leaves resenible a healthy stalk of corn, though

Hardy Grasses

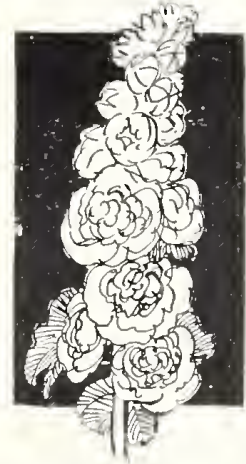

HOLLYHOCKS.
Eulalia iapouier. 5 to 6 feet $A$ haldy crass of robust orow and light green leaves. Used largely for bacliground or centers of beds.

Eulalia gracillima. 3 to 4 feet. This is the most graceful of grasses, and therefore most popular. For indiridual ol mass planting it is

Gulalia variezata. Jong narow leares with prominent white strive. Medium gromer.

Eulalia mebrina. Similar to japonica, being as the name indicates, cross striped with white. 


\section{GAY and COLORFUL IRIS}

1 T

HE. World over, the Iris is known as the Queen of the Garden. Your garden can never be complete unless you have this beautiful flower.

Cultivation of no flower is so simple. It requires very little attention, thrives in poor soil, as well as in fertile, and blooms delightfully year after year. It is astonishingly easy to establish and you will find that it multiplies rapidly.

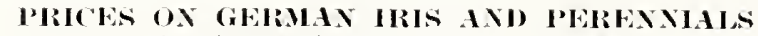

zoc cach, (j for \$1.00, \$2.00 per domen, \$1.5.00 per 100. (A11 $40($ varieties- 5 for $\$ 1.75)$

To get the best success with the Iris. and the most attractive flowers, plant only the better varieties which we have listed here. Figures following descriptions, designate rating given by the Iris Society.

\section{German Iris}

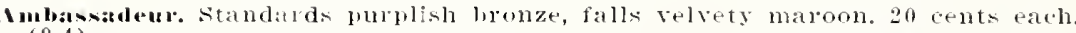
$(9.4)$.

Chester lfunt. Sitandald relestial lolue; falls dalle matrine blur, gu cents each. oream. A solid, soft rlear pink color, 20 cents each. (8.5)

IIer Mojext. Standalds rose pink. Falls bright rrimson. 20 cents each. (7.3). Iris king. Standards clear lemon yellow; Falls maroon margined yellow, 20 Isoline. Standards rose flushed bronzed; Falls mauve with gold tint, 25 cents each. $(8.6)$.

Lat Virge. Pule glistening white, 20 cents each. $(8.3)$.

Lent A. Williamson. Standards lavender violet; Falls pansy pulple; one of the finest. 20 cents each, $(9.6)$.

lohengrin. Tniform lilac rose, 20 rents each. (8.2).

Loreley. Standards light yellow; Falls blue bordered cream, 20 cents each. (i.9).

Ia-Vei. Standards white edged violet: falls white, lavender markings. 20 cents each. (8.1).

Monsizuor. Standards pale violet; falls deep violet. 20 cents each. $(8.4)$.

opera. Standards reddish lilac: Falls velvety violet, 20 cents each. (s.4).

Pallida Dalmatian. Clear deep lavender. Very large and one of the finest, 20 cents rach. (8.8).

Parc de Nuill. Rich plum purple; very gond, 20 cents each. (8.1).

Quaker Lady. Standards smoky lavender, yellow shadings: falls ageratum blue and old gold; odd and attractive, 20 cents each. $(8,4)$.

Queen Vay. Soft losy lilac: looks pink, 29 cents each. $(7.4)$

Hhein-Nive. Standards white; falls violet blue with white edge, 20 cents each. $(8.4)$.

seminole. Standards soft violet rose; falls rich velvety erimson, 20 cents each. (8.3)

Ghelinah. Soft yellow and large, 20 cents each. (S.K).

shewin Wrisht. Golden yellow with no markings, 20 cents each. (7.4).

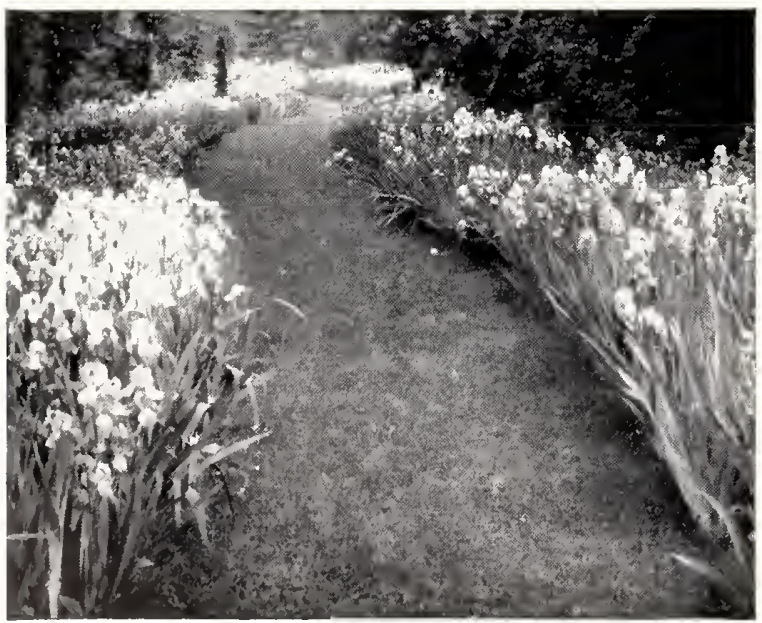

Iris in mass gives a marvelous effect.

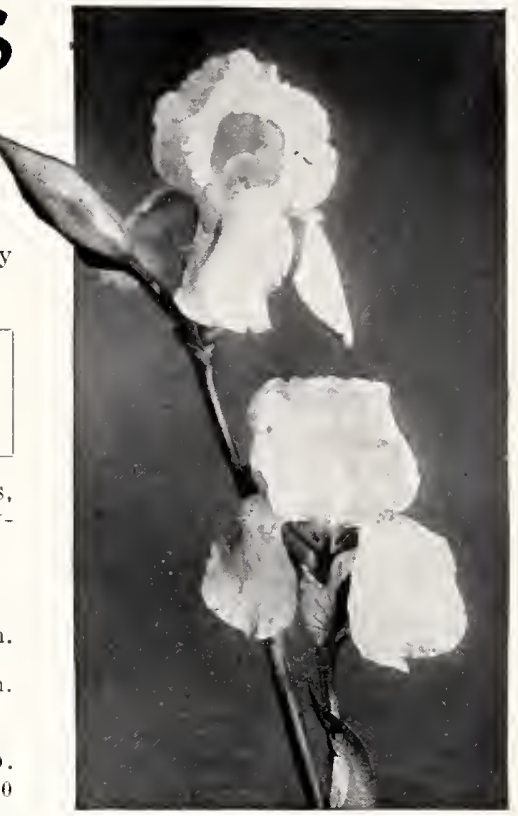

QUAKER IADY.

\section{Japan Iris}

These are not half appreciated. They are the latest blooming and the tallest growing and the most beautiful of the Iris group. They prefer moist but will grow on ordinary soil. They are permanent and we believe you will be pleased with your trial of them. Water well at blooming time. We have tested these for several years and list a
collection of best varieties chosen for color and vigor collection of best varieties chosen for color and vigor only in the Spring.

Price-We offer good clumps at $40($; 5 for $\$ 1.5 .5$.

(A.) Gekka-no-nami. White, base of petals and veins yellow.

(II.) Himaw: Purple with 6 frilled petals.

(C.) Sakita. Delicate lavender veined purple, 3 petals. (1).) Zedo Kawin. Rose with purple markings, 3 petals.

(E.) Ho-o-jo. Mahogany with purple shading, 6 petals. (F.) surprise. Blue lavender and mauve markings, 6 petals.

\section{Siberian Iris}

These follow the German Iris in blossom and prove quite an addition to the garden or border. The leares are thin, long and graceful and the flowers are usually nestled in the foliage just showing their blossoms. More dependable than Spanish Iris and should be planted. We offer two color: Ime -White. Price-25 cents each; 6 for $\$ 1.00$.

\section{LEMON LILY -}

\section{Hemerocallis}

These are popular, sweet scented lemon yellow lilies flowering in June and growing about two and a half to thre in height. Thrive in both cations as well as full suliont.

\section{PACHYSANDRA} -Japanese Spurge

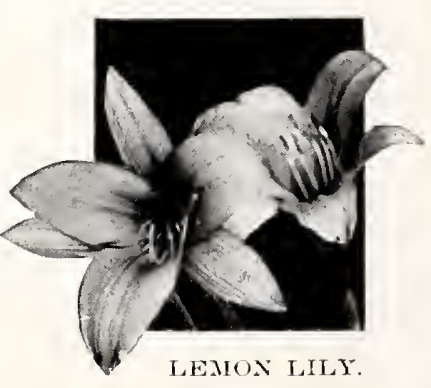

Fine evergreen ground cover for shady locations. Once established makes a perfect mat. Very good to use with evergreens or under trees where shade leeps the grass from growing. 
PEONIES

Tested Varieties Best for Kentucky Gardens

P'EONY PRICES

$\$ .50$ varieties. . . . . . . . for $\$ 2.00$ $\$ 1.00$ varieties. . . . . . . . .5 for \$ \$1.50

(Your assortment)

White Peonies

unromess selumeder. A very delicate flesh pink, fading to white with suggestion of heliotrope and gold. Midseason. 50 cents each.

Festiva Maxima. The grandest of the whites. Early. The flowers are extra large, color a pure white save tipped petals. 50 cents each.

Conronne d'or. A cream colored white, compact blossom and very desirable. Late. 50 cents each

Mad. de Vemeville. Another very desirable white variety, free bloomer and should be in every collection. Early. 50 cents each.

Marie Jactuin. This is almost single, having only double row of outer petals. A favorite with every one. Midseason. 50 cents each.

\section{Red Peonies}

Francois ortegat. A midseason to late variety, being very dark rose color with yellow stamens; flower large on strong stems. Extra good. 50 cents each.

Felix Crousca. A midseason variety of the most pleasing velvety red color, fading to lighter shades as the blossom falls. 50 cents each.

Karl Irosenfield. Rose type, late midseason, with large, triking. 1100 vach.

\section{Pink Peonies}

war Gray, A soft shell pinli, mottled and veined rose. Midseason, and plant vigorous. 50 cents each.

Edulis superha. Another deep rose of different season, glued for its fragrance and

Larly . Durr. Rose type and an unusual delicate flesh pink. One of the most striking of all peonies, with extra large cup shaped flowers. $\$ 1.00$ each.

LaPerle. Deep lilac white, blush center flecked carmine. Medium sized rose type and fragrant. 50 cents each.
Livingsone. Late; clear pink. Very fine. 50

Madam Emile Galle. Rose type, late midseason. Color very delicate pink with cents each.

Marsuerite Gerard. Another delicate pink, midseason of great vigor and size. 50 cents each.

Milton Hill. Rose type, very late, large, clear flesh ol shell pink Turns almost white before falling. $\$ 1.00$ each.

Mons. Jules Hie. Large compact, lilac-rose with lighter pink base petals. Fragrant. Early to midseason. $\$ 1.00$ each.

Teurs. Pale hydrangea pinl, large, compact crown. Midseason. 50 cents each.

Oetavie Demay. Very early, large flat flowers, center deep pink, guard petals lighter flesh or white. Fine fol cutting. 50 cents each.

Heine Hortense. Rose type, midseason, large, flat, flesh pink to shell pink. Very fragrant and one of the finest. $\$ 1.00$ each.

Saral Beruhardt. Semi-rose and late. Very large flowers, apple blossom pink with silver tipped petals.

\section{Single and Japanese Peonies}

Ikilu (Japanese). Guards deep American Beauty shade, petaloids conspicuous saffron yellow margined rose. $\$ 2.00$ each.

Clairette. Single white of unusual beauty. Large floweach.

Duehess of Portland. Single and reloy delicate shade of flesh pink. Large and vigorous. $\$ 1.00$ each

Josephime. Single rose pink, of lasting qualities, Stamens yellow. $\$ 1.00$ each.

Perle Rose. Light pink with petals edged silver rose. $\$ 1.00$ each.

llosy Dawn (simlle). Large snow white flower with very delicate blush shading in the bud. $\$ 1.00$ each.

IRuicemu (Japanese). Dark ma roo $\mathrm{n}$ with petaloids most pleasing yellow. Very showy. $\$ 2.00$ each.

Snow Wheel (Jamanese). Pure white, large petals. Petaloids, too, are white. Our best white Japanes
variety. $\$ 1.00$ each.

'The Noot: Very striking deep rich red of unusual beauty. Stamens yellow and striking. $\$ 1.00$ each.

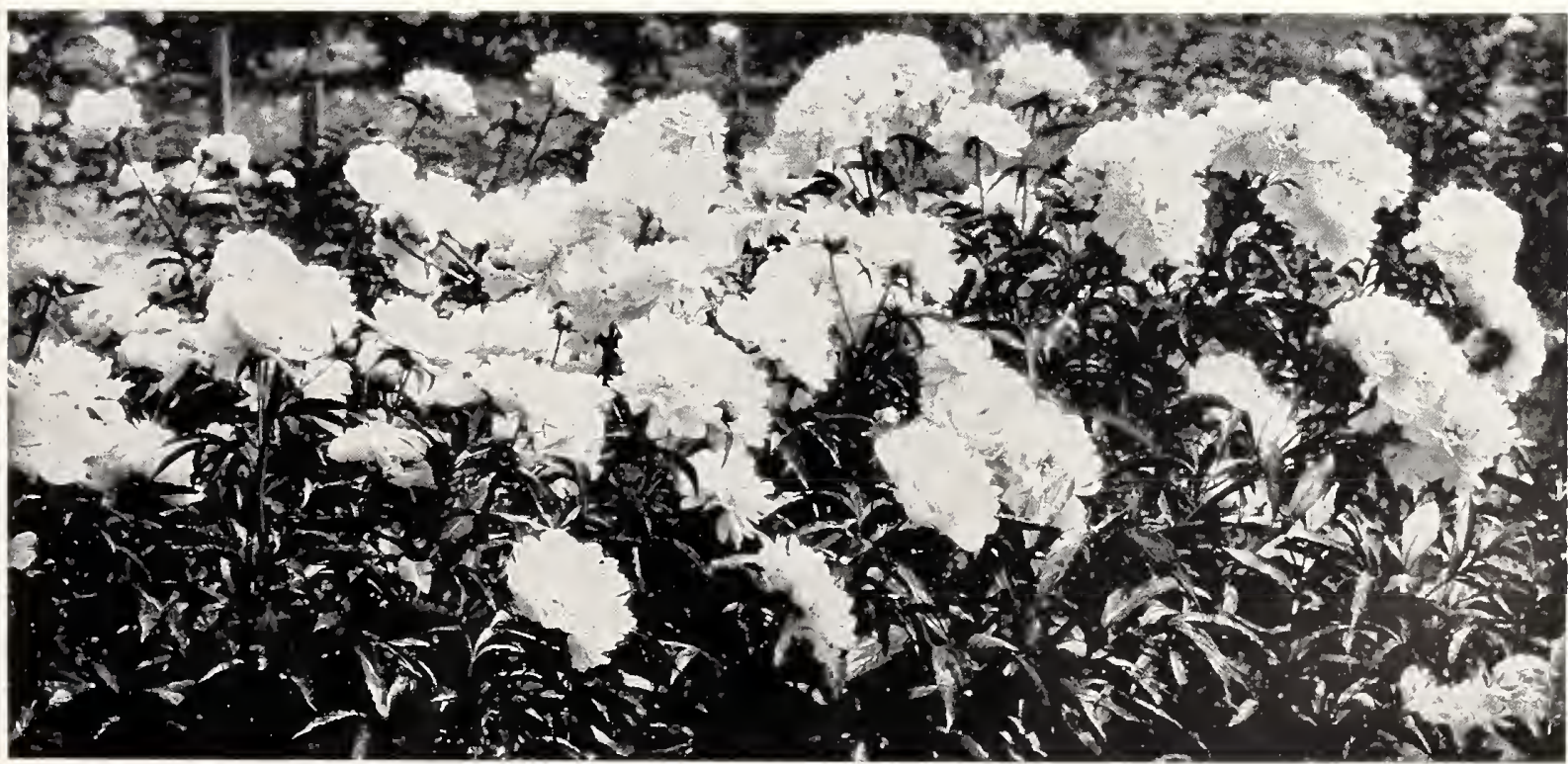

For a truly gorgeous display of fine blooms, year after year, plant Peonies.

Try a few new varieties of Peonies. We have a fine selection. 
Periwinkle or Trailing Myrtie

An old fashioned trailing evergreen plant used for ground cover under trees or where it is too shady for grass or other plants valuable for ground cover, succeeding better than anything else in this section.

\section{Phlox}

We offer the finest of the summer blooming phlo: earty and tate blooming varieties.

Beacon. Brilliant Cherry Red.

Ethel Pritchird. French mauve to pale blue.

Frau G. Inn Iambur. Late White, immense panicles

Iiss Linwarl. Earliest white, long graceful panicles

Rlueinlander. Salmon Pink.

Sir Edward Landsecu. A bright copper crimson.

Thor. Deep salmon pink, aniline red eye.

Plitox subulara (Mox or Muuntain Pinlis). One of the ealliest spring flowering perennials with moss-lilie evergreen foliage which is hidden under its mass of bloom. An excellent plant for the rockery, border or for carpeting the ground. We offer two varieties, lilacina. which is a light lilac, and Rosea, a pink which thrives in hot, dry locations.

\section{Pinks}

Hardy double valiety of peremial Pinls, often called Florist's Pink. 1 foot. Blooms profusely in June, Valuable for rockery

\section{Plantain Lily or Funkia}

Pure white flowers with large for leaves, Especially fine for shady spots. 1 to 2 feet. July cents each.

\section{Platycodon-Japanese Bellflower}

This comes in blue and white Blossoming in July, the attrac tive flowers, often three inches across, come in succession for sevelal weeks, Height, $21 / \frac{1}{2}$ to 3 feet.

\section{Poppies}

These are Oriental Poppies, vivid shade of red, blooming with the peonies, and the joy and admiration of everyone. Plant a few of our division and have flowers the first season, 2 to feet. We advise fall planting only. Prices same as other per

Irs. Perry. We offer this named pinli variety with dark mark ings and of a most attractive
shade. Special Price 4oc each.

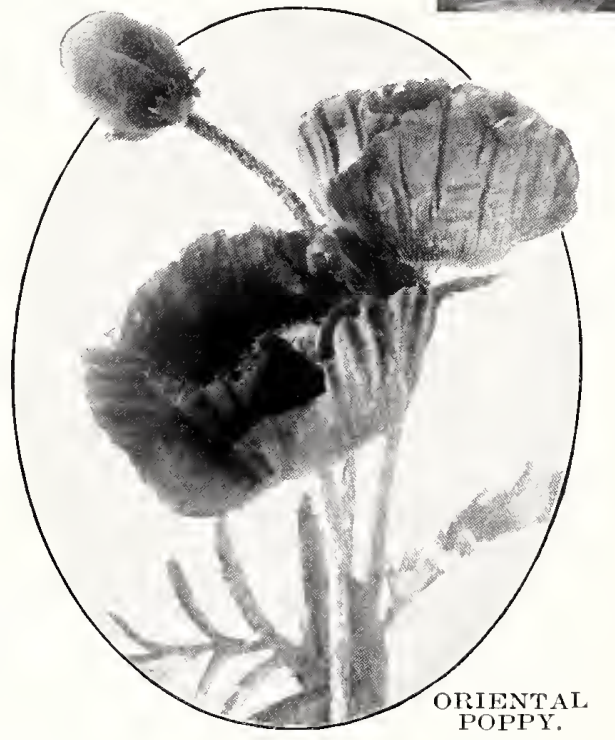

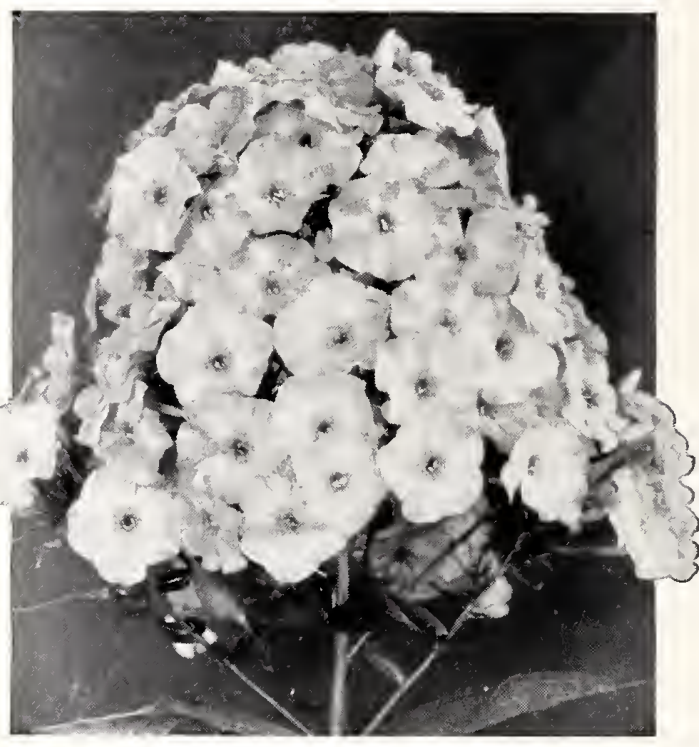

PHLON RHEINIANDEI:

Pyrethrum - Painted Daisy One of the most desirable peren nials blooming in May and mials blooming in May and sliades. 2 to 3 feet.

Rudbeckia-Golden Glow

A yellow blooming perennial that has become popular in a very short time since being introduced The Howers in July and August ale like small Chrysan themuins borne on the terminals of 5 to 6 feet stalks. Very desirable.

\section{Sea Lavender}

tutice latifolia. 2 feet Blossoms in late sunmer, having a pro fusion of small blue fowers

PRICIES ON PERENNIAIN

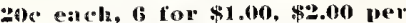
dezen, \$15.00 ver 100.

( 111400 varieties-

\section{HOW TO PLAN A PERENNIAL BORDER}

The question most difficult to answer in correspondence is, "How do I lay out a Perennial Border? The design to the right shows a typical arrange ment

The edge of the border, except in very formal plantings, should be gracefully curved. The plants should be placed about two feet apart: that is average, but apart; that is average, but edge should be closer. Place the taller plants in the background. Better effects nials are planted in groups of three or five or more Such grouping gives the ef fect of one large plant, and when in bloom they attract more attention and give more pleasing effects. Note also the "sliy line" is not a straight fence or hedge effect but undulating and, therefore, mole interesting.

An effect such as illustrated requires about 50 plants. On the plan the dots indicate individual

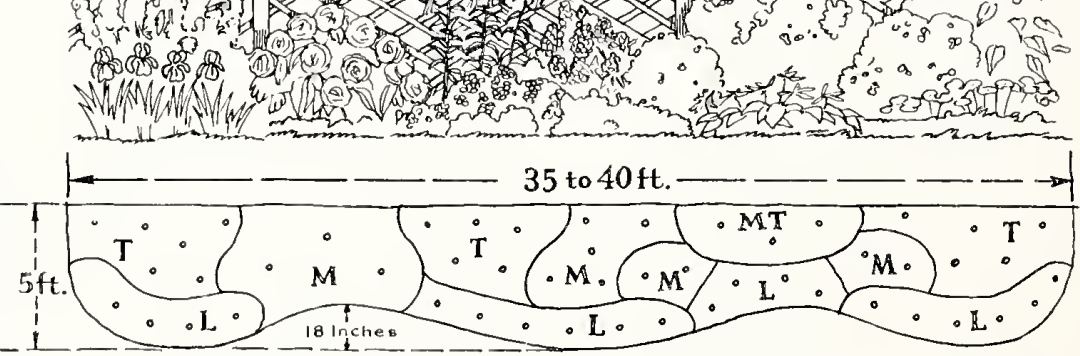

plants. One variety is planted in each division (L) indicates low-growers; (M) indicates mediumgrowers; (MT) indicates medium-tall growers, and ( $T$ ) indicates tall varieties. All our listings give the height of growth for each variety so you can easily determine then proper relationship. Free-blooming annuals should be planted to supplement the perennial border for blossom display. 

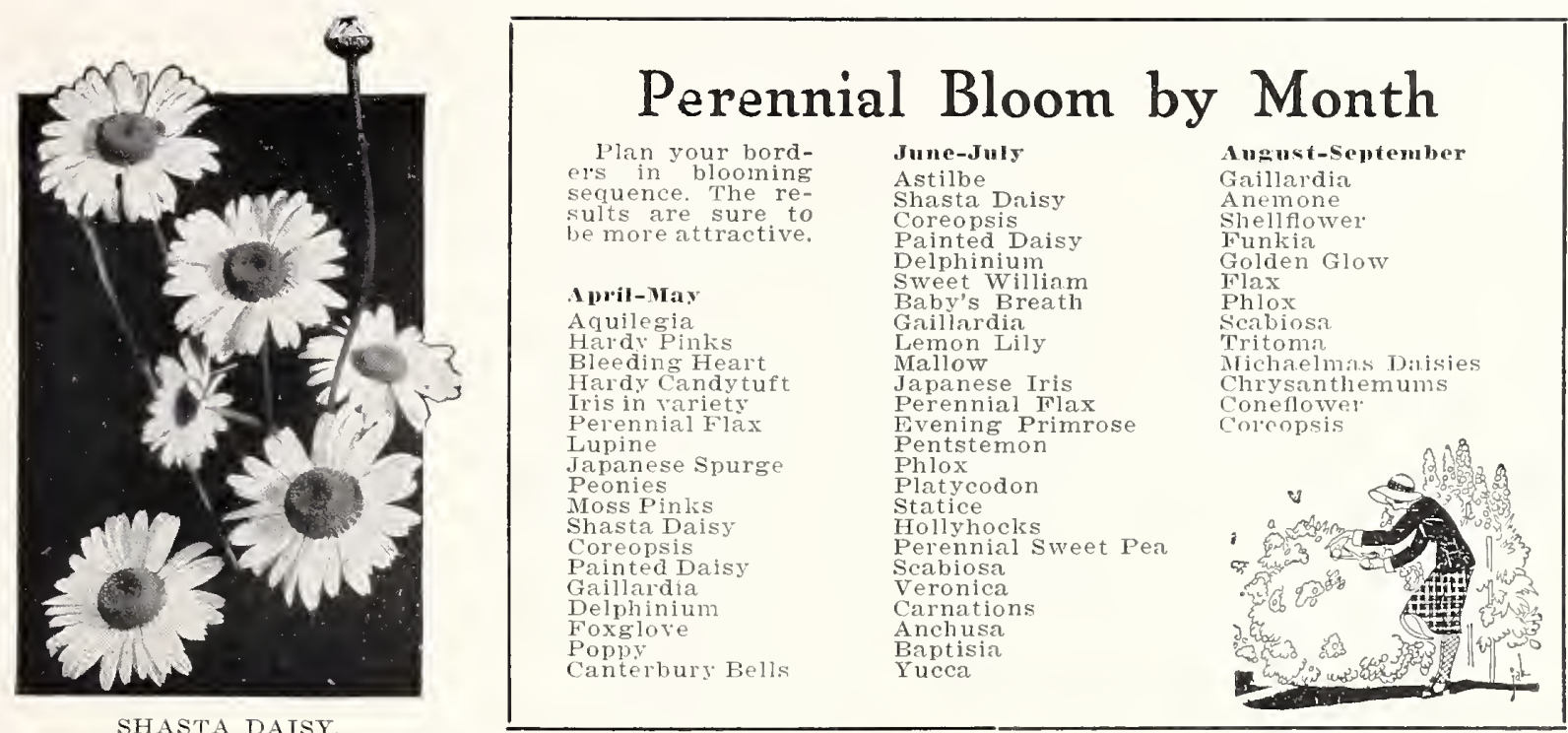

SHASTA DAISY.

Sedum or Stonecrop

Thick cactus-like leaves that are attractive from early spring, producing flat terminal clusters of pink flowers in August and september.

\section{Shasta Daisies}

Vigorous growing plants, height two and a half to three feet, useful for cutting, and a most popular perennial. We offer two strains, extra early blooming one and the large fowering Alaska type. Specify when ordering.

\section{Speedwell-Veronica}

One of the finest blue flowering plants, increasing in strength every year. Medium size spikes completely hidden with two feet.

\section{Sweet Pea} Lathyus latifolius. This is a hardy vine, robust growing
and fine foliage. Flowers in shades of pink, continuous blooming from June 10 frost.

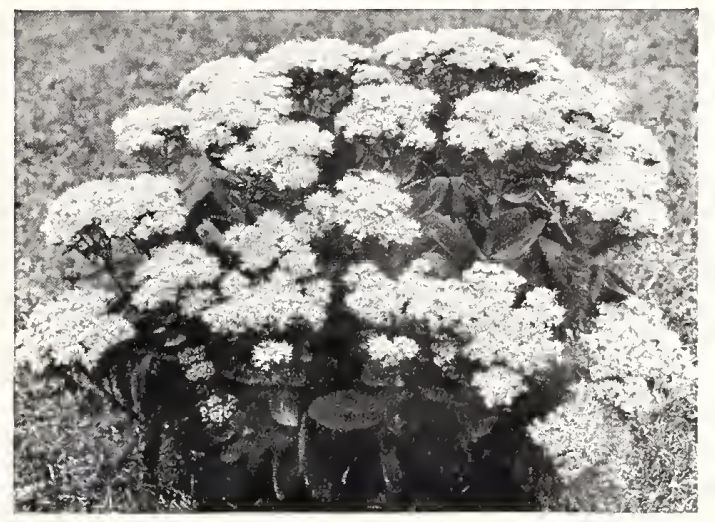

SEDUM SPECTABILE-SHOWY SEDUM.

\section{Sweet William}

Another good old-fashioned plant, so well known that description is not necessary. Flowers in June and is a picture with its white, violet and crimson blossoms. No old-fashioned border is complet. without their cheerful, sweet-smelling and showy flowers. 18 to 24 inches.

I ir. Newport pinks. These are similar to the above ordinary swcet William save in color; all are light salmon pint.

Stokesia (Cornflower Aster)

A free blooming perennial, $2 \frac{1}{2}$ to 3 feet, having bluish larender blossoms 3 to 4 inches across.

\section{PERENNIALS for the ROCK GARDEN}

Everybody is making Rock Gardens nowadays, and makin. them in all sorts of ways. No two gardens present quite the same problems, and no ready-made solution will answer all the conditions. The compactness of a rock garden is one of its greatest charms. If there is not space in the open to build one,
it may be tucked into an odd corner of even the smallest lot.

Rockery Plants are a specialty in themselves, but for a modest planting the following are generally successful.

$\begin{array}{lll} & \text { Iris, German } & \text { Vinca } \\ \text { Aquilegia in variety } & \text { Iris, Japanese } & \text { Pachysandra } \\ \text { Delphinium } & \text { Iris, Siberian } & \text { Statice } \\ \text { Geum } & \text { Oenothera } & \text { Gypsophila } \\ \text { Heuchera } & \text { Phlox subulata } & \text { Viola } \\ \text { Iberis } & \text { Sedum } & \text { Ete. }\end{array}$

SPECIAL ROCK GARDEN LIST IN SPRING

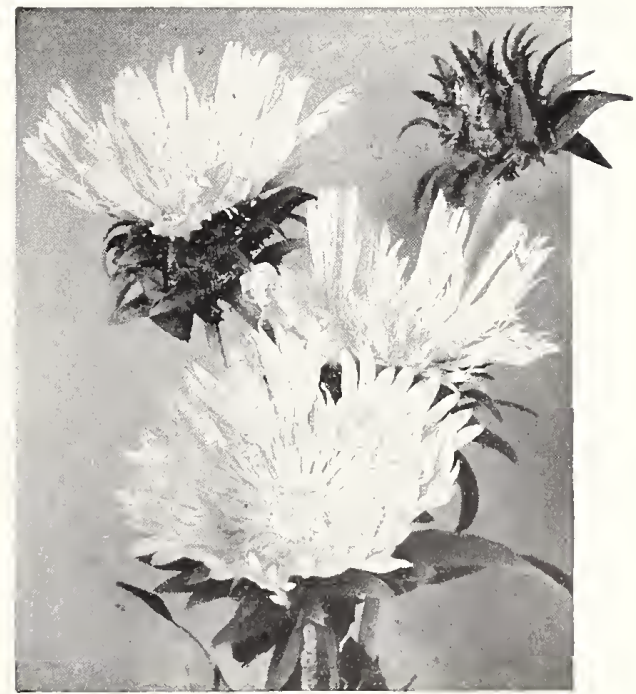

STOKESIA.

PRICIS ON IERENVIALS

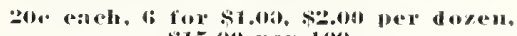
\$15.(4) per 1 (ot).

(11 Hoc virieties-5 for: $\$ 1.75)$ 


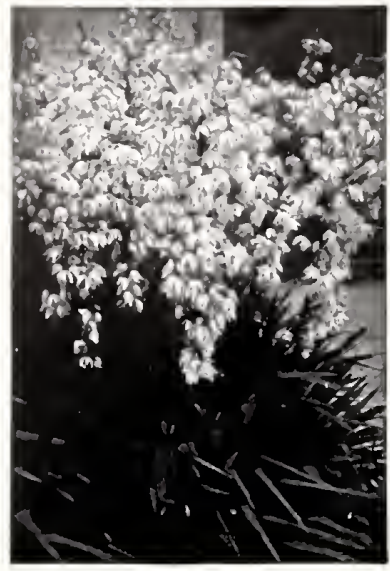

EVERGREEN YUCCA.
Tritoma-Red Hot Poker

This blooms from July until fiost time. The fower spikes are the drooping green leaves several feet. It is rather unusual and attractive, 2 to 3 feet.

\section{Tufted Pansies-Violas}

Mersey Gem. Dwarf habit and continuous in bloom making a bushy growth resembling the English bedaing rolets. Color a rivid rolet. slightly perfumed and should be pruned several times during the season so the blosson spikes do not go to seed.

\section{Yucca filamentosa}

dau's veedle or 'Thread Plant A stately evergreen thread-leaved plant producing spikes of creamy white flowers, borne on tall stems. The individual flowers resemhle the tubecose Desirable to plant about a grave or wherever it may raise its majestic head in full array. June.

\section{PRICES of PERENNIALS}

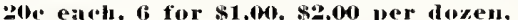
\$15.00 ver 100.

(111 40e varieties-5or $\$ 1.75$ )

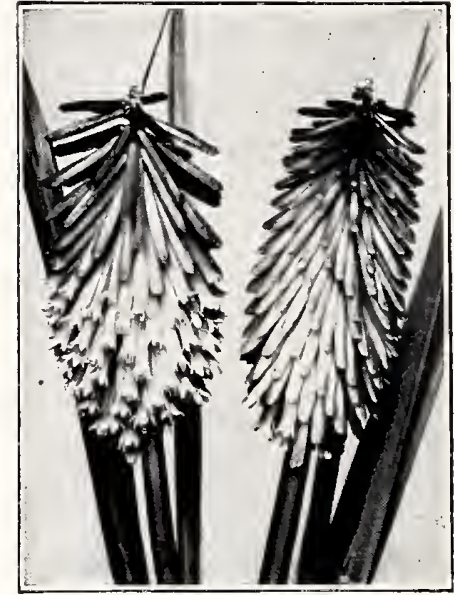

RED HOT POKER.

\section{HAVE a BETTER LAWN!}

\section{Use Hillenmeyer's Famous Kentucky Blue Grass Seed}

The finest Blue Grass Seed obtainable is grown right here in Kentucky. We have made a specialty of supplying our customers with the best grade of seed which has high germinating qualities and is free of troublesome weed seeds. The preparation of the soil is the more expensive item so why gamble with questionable seed?

For New Iawns Try Our Specially Prepared Mivture.

For Re-seediuge Try Our Pure Blue Grass.

Never sow until your grade is established, the soil leveled and seed bed thoroughly prepared, as you cannot grade or loosen the soil after your seed is planted. Rake in very lightly or, preferably, roll, but do not cover too deeply. In no case attempt to plant in unprepared soil as not only physical condition but fertility is important. Any of the standard fertilSeptember to May. On new plantings it is advisable to use a nurse crop, that is, something to shade the grass. Rye, oats and buckwheat are all very good for this purpose. Do not cut too close the first year and by all means keep well watered. Fertilizing at least once a year is advised on poor soik. A pound will cover approximately twenty-five by twenty-five feet. In sowing spots on the lawn, be sure to loosen the soil with a sharp rake.

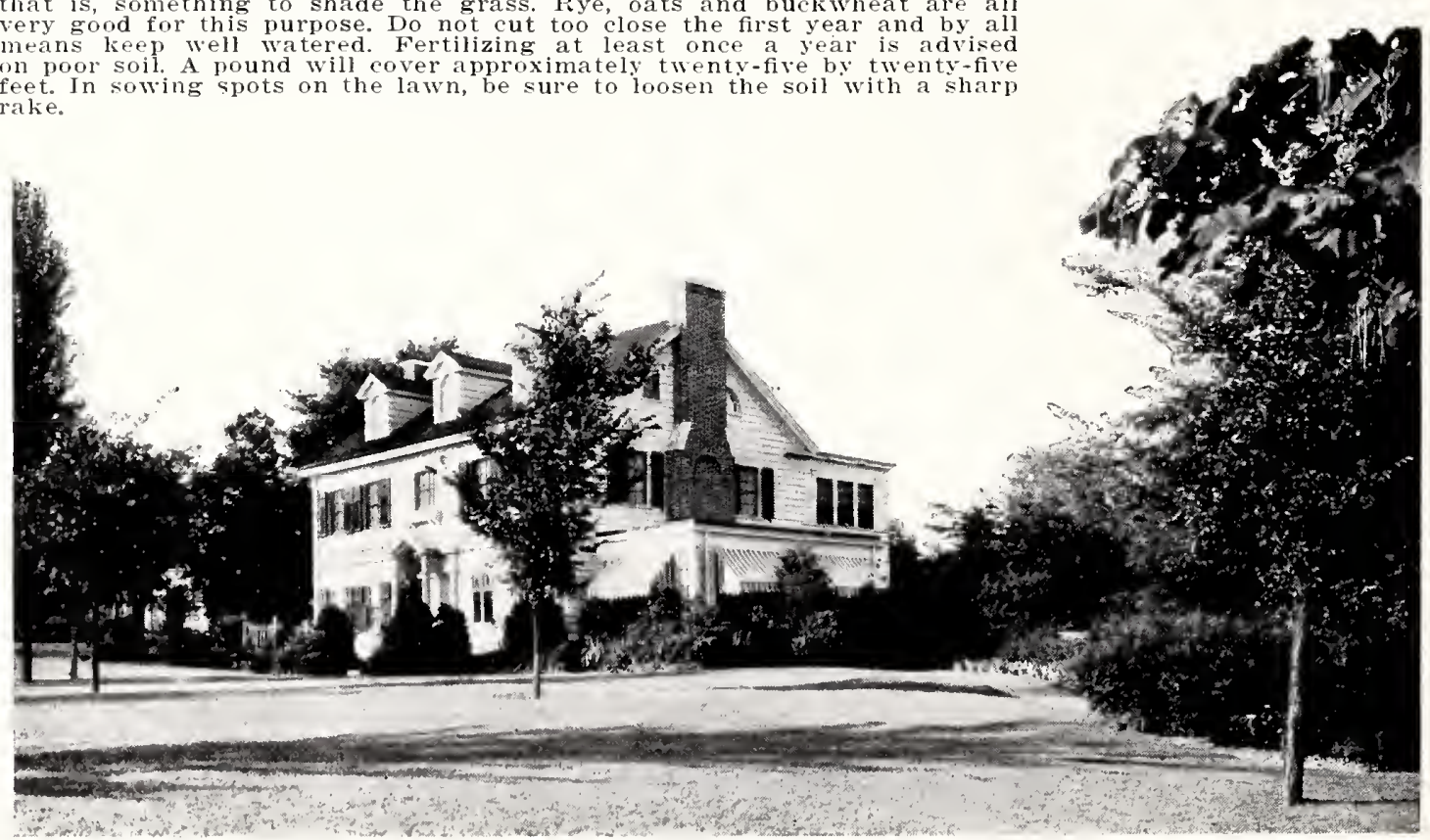

No element in the landscape picture lends more beauty than a good lawn well maintained.

GRASS SEED PRICES

Hillenmeyer's Pure Blue Grass. OI.

Lawn Mixture

1 lb.......40c Postpaid

3 lbs......\$1.00 lostage, 10e

10 lbs... . . \$33.00 Postage, 20c

Quantity lots quoted specially. 


\section{FRUIT DEPARTMENT}

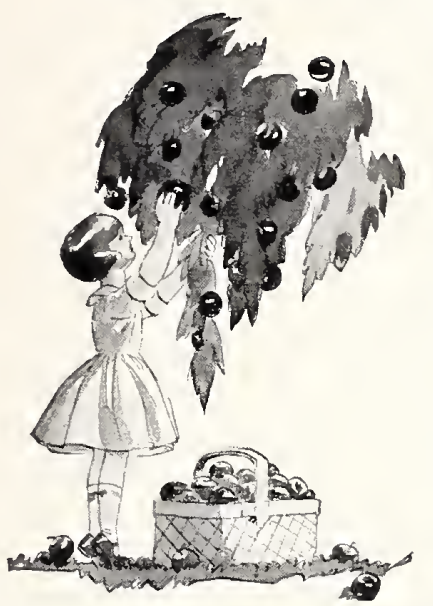

We are still believers in "Grow Your Own Fruit" and we have a fine lot of trees for fall and spring sale

We propagate our fruits under careful conditions, taking every precaution to have them true to name for we believe dependability of variety is our very best sales argument. We guarantee every variety to be as described and hold ourselves ready to replace, without charge, any tree that accidentally proves untrue to name. In addition to this dependability our trees are suited to nearby conditions as we test all varieties before offering them for sale. As we sell direct we ask no fancy prices for our stock.

\section{AS EXPERIENCED FRUI'T GHOWETS WE SUGGEST}

-that you plan for a succession of fruit, increasing quantities where you expect to market or store. It is inadvisable to plant too many varieties in the average orchard. There is no reason why you cannot have fresh fruit from the time that Cherries ripen in May until well into the winter. We will help you plan your list if you will ask us.

-tlat you cultivate your newly planted trees, for it is just as important to eultivate them as is to oultivate a tomato or tobaeco plant. Only after the tree has become toll established should cultivation stop. Fren then voul trees will respond te fertilization and eultivation. - that you feed young trees to promote health and vigor. Nitrate of Soda, Sulphate of Ammonia, Bone Meal, Manures, or similar soil builders applied in moderation often spell the difference between success and failure. Strong, vigorous trees can stand unfavorable weather conditions, fyost and even disease. Good soil means early maturity and heavy yields.

-that where space is scarce, you plant quick maturing trees like Peach, Plum and Cherry, in the center of the squares between late maturing trees. The former should be taken maturing trees. The former should be taken crowd. Don't plant too closely (see planting chart to left).

- that you renew your plantings of Peach trees every four or five years to keep a continued crop coming on.

\section{How to Plant and How to Prune}

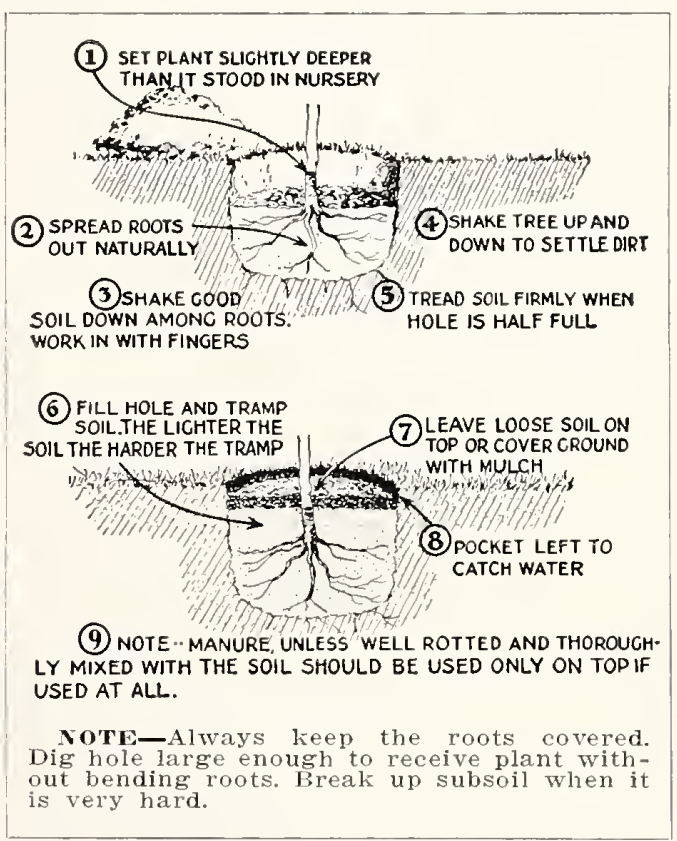

IOw TO PRUNE. In pruning Apple, Plum Cherry and Pear trees, cut the side branches to 6-8 inch stubs and do not leave tree. See that these are distributed around the trunk. The peach tree requires a little more severe

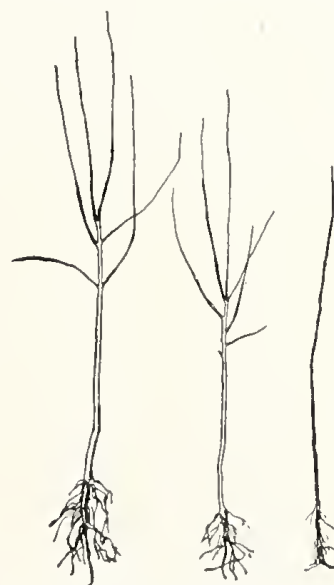
are simply headed to whatever height they are wanted.

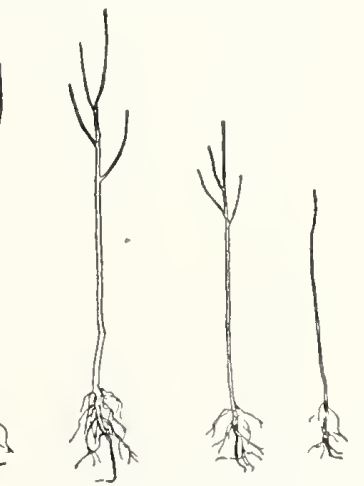

BEFORE PRUNING. AFTER PRUNING.

A three-year-old, two-year-old, and a one-year-old apple tree before pruning and after pruning. Try ot to have two branches nearly opposite will form a bad crotch when the tree is older. 


\section{HAVE an APPLE!}

\section{Apples are the most valuable and} desirable fruit and no place should be without a few trees

P ROPER selection of a complete or-
chard should consist of fifteen per cent summer, twenty-five per cent fall and sixty per cent winter varieties. Do not plant too many varieties.

The filler system, that is, the interplanting between the rows of permanent "ruits with quick maturing trees, like peach and plum, is suggested on plots where space is limited. These fillers are to be taken ont as they crowd.

\section{How to Grow Apples}

Apples prefer a well drained and fertile soil. Refer to page forty-one for cultural directions and also graphic on how to prune. Orchard pruning is covered in a Bulletin we have available and likewise latest information on spraying. These will be sent on request.

PRICES: Two year old trees.

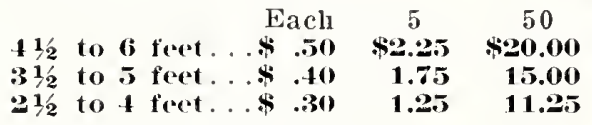

\section{Early Apples}

rod Astrach:m. Excellent red apple, ripening in July. It is tart, best cooking apple hand. should be in every orchard.

Ienoni. Attractive, red, best eating apple of its season. Early bearer and very productive.

Larly Harvent. Pale yellow, sub-acid, regular bearer and is the most popular of the old general purpose varieties.

carrly 'Transparent. Very early bearer, productive; valuable for either home or waxy yellow, talt, excellent.

raldan sweet. The best sweet we know Yellow; vigorous grower; productive. Hasn't a fault.

IIslon, Crall. This is undoubtedly one of the very best hardy crabs producing a heavy crop of tart, bright red fruits that are unexcelled for
ind productively

livelambl sucweds eterywhere; very momisn commerical and home variety. An extra eatr

Maiden's mush. A grand old favorite. Waxy yellow, pleasing red blush. Pipens over a lon period, making it valuable for home orchards.

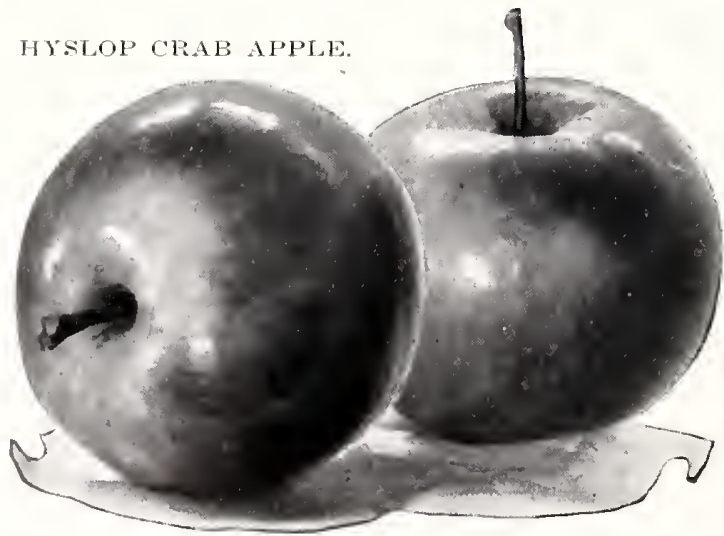

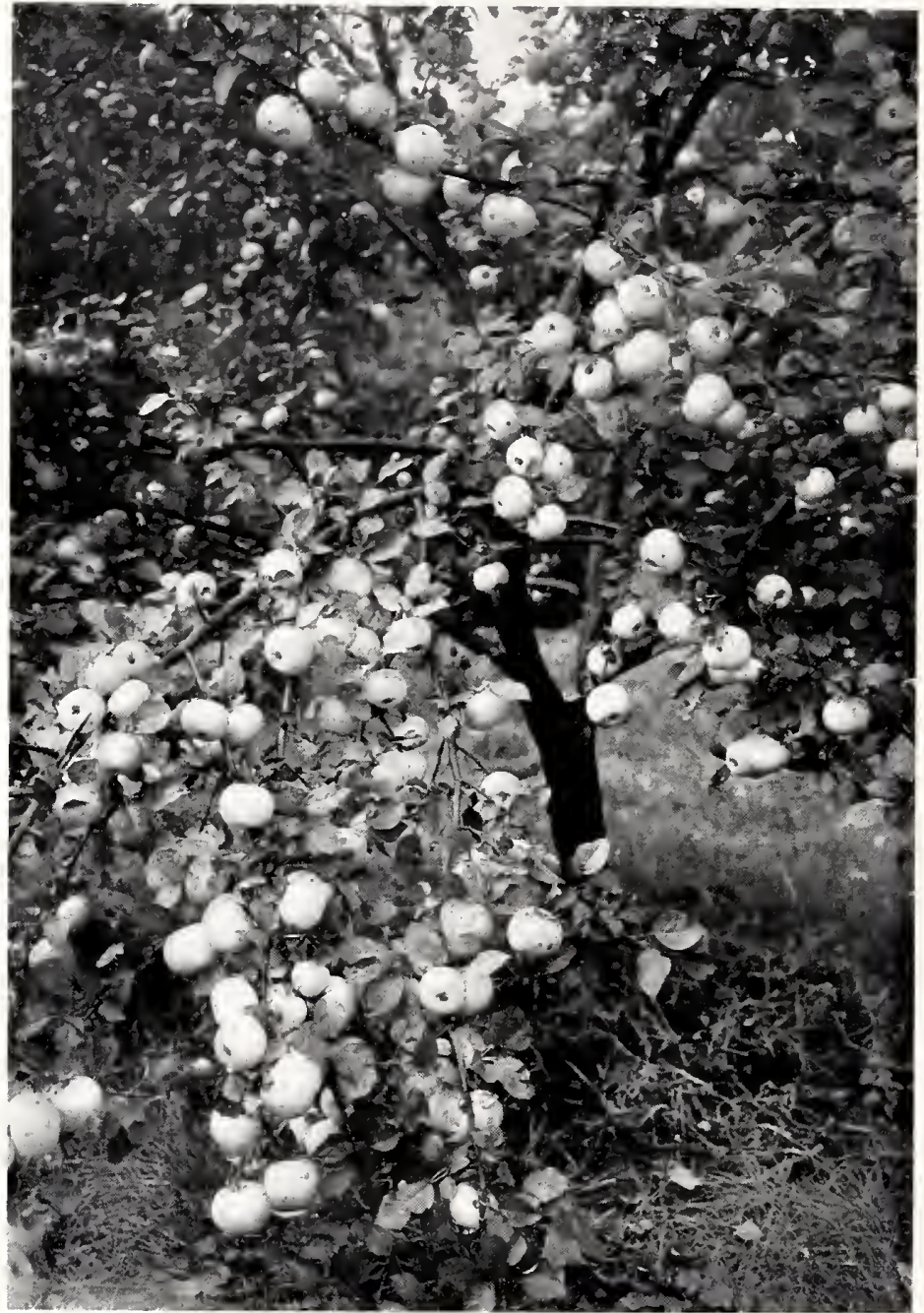

WINESAP APPLE.

\section{Fall Apples}

Grimes ciolden. This is the very best fall apple for this section. A recent survey showed it was the most popular apple of any season. It matures early, and is the of a rich golden yellow, excellent for eating and the best all around apple of any season.

This variety is troubled with canker, which shortens the life of the tree. We offer "DOUBLE LIFE" GRIME. GolDEN at 25 cents extra, in addition to standard egular prices.

Vorthern Spy. Large striped. Crisp, juicy, aromatic, Excellent quality. Long coming into bearing.

Weallis. Large, shaded to dark red, quality good, tender and productive. Early to bear and very satisfactory.

Wolf lliver. An attractive large striped apple, ripening in september. Owing to its size it finds a ready market. Coolis well. Matures early.

\section{Early Winter Apples}

II:Illwill. Red, large, fine quality, tree vigorous. Commercial apple of the east

Ben Davis. Striped red, large and attractive. Surest bearer, healthy tree, vigorous and should be planted as a "catch" in every orchard. Greatest fault, lacks
quality. 


\section{Early Winter Apples-Continued}

Black 'Tris. A seedling of Winesap. Lalger, splashed with red, sub-acid and rery productive. We can es pecially recommend this for Kentucky. Taluable for home or market. Plant it.

Delicions. Fed, large and uniform in size, distinct because of five lobes on blossom end. Variety new, very popular and no orchard should be without it. Quality unexcelled. A very early and heavy bearer; for market and home.

Jounthiu. An early bearing variety, red, medium size and quality very good. Tree never large but productive.

Milım. A standard for fifty years, Quality excellent, color red; size medium.

Rome Beauty. Large red, tender and sub-acid, early bearer and productive. A sections and a very popular vections.

stayman Winesap. Dark, rich

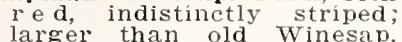
Tree productive, stands drought. The most extensively gr. The most extensively

good qualities in its favor than anything we offer for Kentucky.

Winesap. Medium size, dark red, productive variety, excellent quality, crisp and juicy; sub-acid.

York Imperial. A late keeping commercial variety, shaded red on yellowish skin, flesh firm and tree healthy. Regular and heavy bearer. Plant for profit or Ior home.

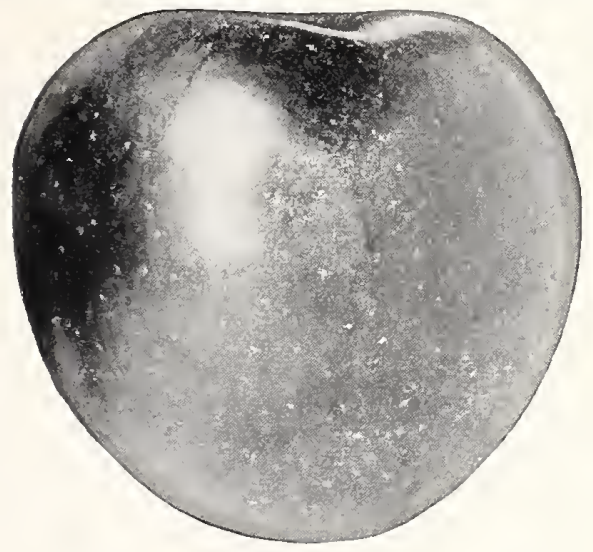

STAYMAN
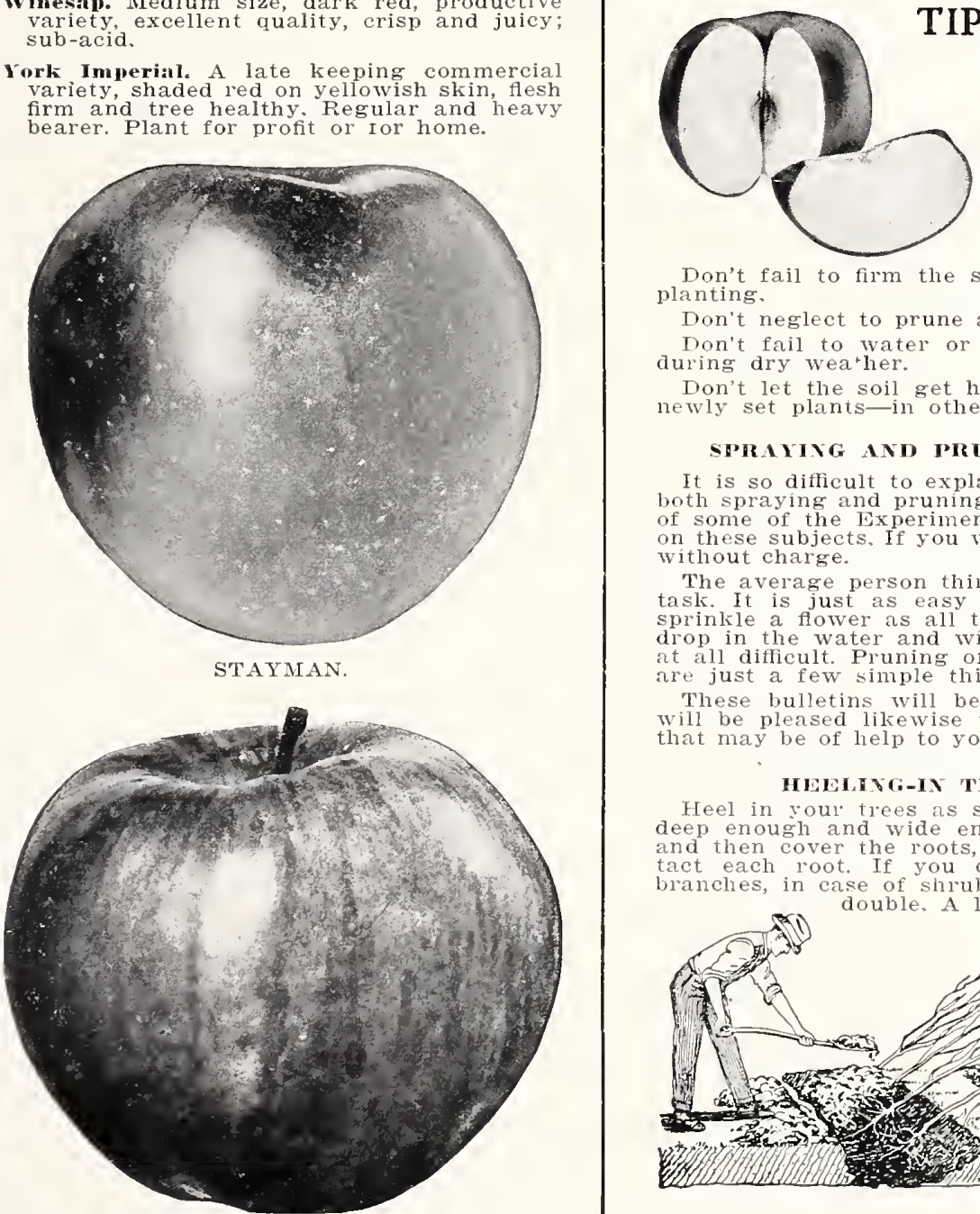

\section{TIPS to the Fruit Grower from Hillenmeyers} Don't let the roots dry out
from exposure to wind or sun.

Don't plant in soil too wet or too dry.

Don't plant in hole so small that the roots are crowded.

Don't fail to firm the soil well about the l'oots when planting.

Don't neglect to prune as directed.

Don't fail to water or cover the ground with mulch during dry wea'her.

Don't let the soil get hard or let weeds grow around newly set plants-in other words, cultivate.

\section{SPRAYING AND PRUNIYG BULLETINS FIEL}

It is so difficult to explain all the necessary details of both spraying and pruning that we keep on file a supply of some of the Experiment Station Bulletins and others on these subjects. If you will write us we will mail them without charge.

The average person thinks that spraying is a dreaded task. It is just as easy almost to spray a tree as to sprinkle a flower as all the materials can be bought to drop in the water and with modest equipment it is not at all difficult. Pruning of trees is not difficult as there are just a few simple things to keep in mind.

These bulletins will be sent without charge and we will be pleased likewise to ansiver any other questions that may be of help to you with your problents.

\section{HELIABG-IS TREES AND SHIEIIS}

Heel in roul trees as soon as received. Dig at trencl deep enough and wide enough to take the root system and then cover the roots, firming the soil so as to contact each root. If you cover some of the trunl (or branclies, in case of shupus) with soil, the protection is double silutection is

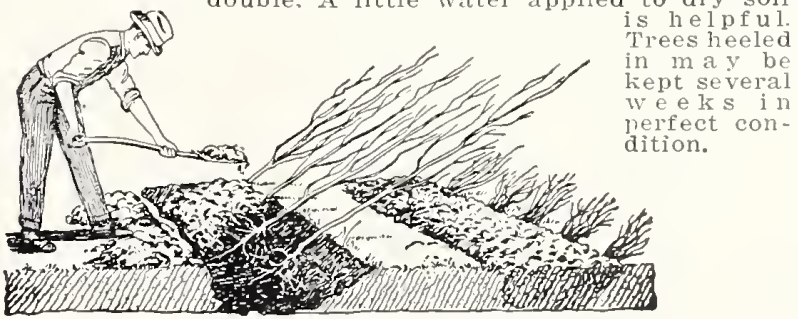

WEAITHY APPLE.

Hillenmeyer's apples are true to name and the best grade of trees you can buy. 


\section{PEACHES are PROFITABLE}

(1)

UCK bearing qualities and a ready market combine to make peach growing a good paying proposition.

IRICls: Two-year-old roots, one-year-old tops.

\begin{tabular}{|c|c|c|c|c|}
\hline & & $\mathrm{ach}$ & 5 & 50 \\
\hline$+1 / 2$ & to ; f feet .......... & .50 & $\$ 2.25$ & $\$: 20.00$ \\
\hline $31 / 2$ & 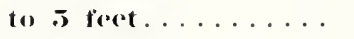 & .40 & 1.75 & 1.5 .00 \\
\hline $21_{2}^{\prime}$ & to: $33^{1 / 2}$ feet... & .30 & 1.2 .5 & 11.25 \\
\hline
\end{tabular}

\section{Early Ripening}

Arp Heanty. Best extra early yellow mottled with crimson. Quality better than Red Bird or Greenslike all extra earlies but very fine.

Mayfower (Free). Red all over, fine and good. Farliest peach linown. June 25th. Extra hardy.

\section{Second Ripening}

Belle Geormia (Free). White with decided blush: excellent quality; heavy and regular bearer. In this variety we have the best white-fleshed peach for home or market. August 5 .

Iratkett (Free). Orange-yellow mottled and blushed carmine. Large, quality the best. Really is a late Elberta and should be in every orchard. August 25.

Carman (Free). White with red blush. Carman is extra hardy, bears every year, and when it fails all else fails, too. Tree a lobust grower and produces heavily. Next to Elberta, Carman should be considered. We are partial to it. July 20 .

Early Elberta (Free). Well named, being a clear yellow with blush. finer grained and sweeter. Tree a strong grower, with a tendency to thin itself, carrying moderate loads of fruit. August 10 .

Champion (Free). White fleshed, with attractive red cheek, juicy, good quality and dependable. August ripening.

Erberta (Free). Beautiful yellow, large and shaded with deep red. Flberta has been the peach for years, with deep red. Flberta has been the peach for years, 80 per cent of commercial plantings are of this variety speaks well enough for it. August 15.

J. H. Hale (Free). Yellow, almost covered with red more highly colored than Elberta: flesh firm, melt ing and of best quality. Ripens August 10-15.

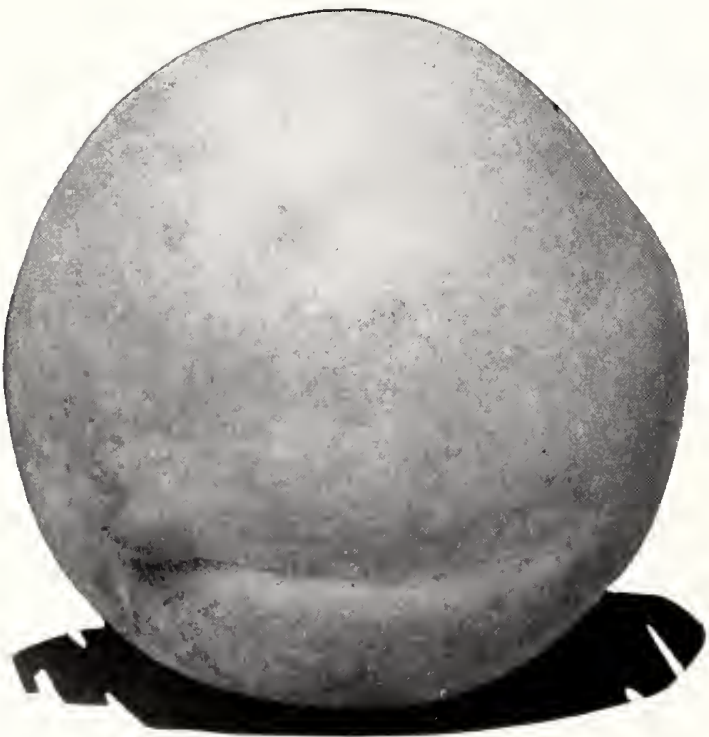

J. H. HALE PEACH.
Hiley (Free). Follows Carman but an early Belle of Georgia. A fine white flesh, free stone peach, better in quality than any of its season. Flesh firm, sweet, good quality, and is a good market variety. July 30.

\section{Late Ripening}

Chairs Choiee. We thought we had a better peach in this one so discarded Krummel. This is so nuch better, ripenino in September, a big round golden yellow witn blush. Best late freestone.

Heath (Cling). White, tinged next to the sun. A arre, firm juicy peach of most pleasing flavor. Well known. October 1.

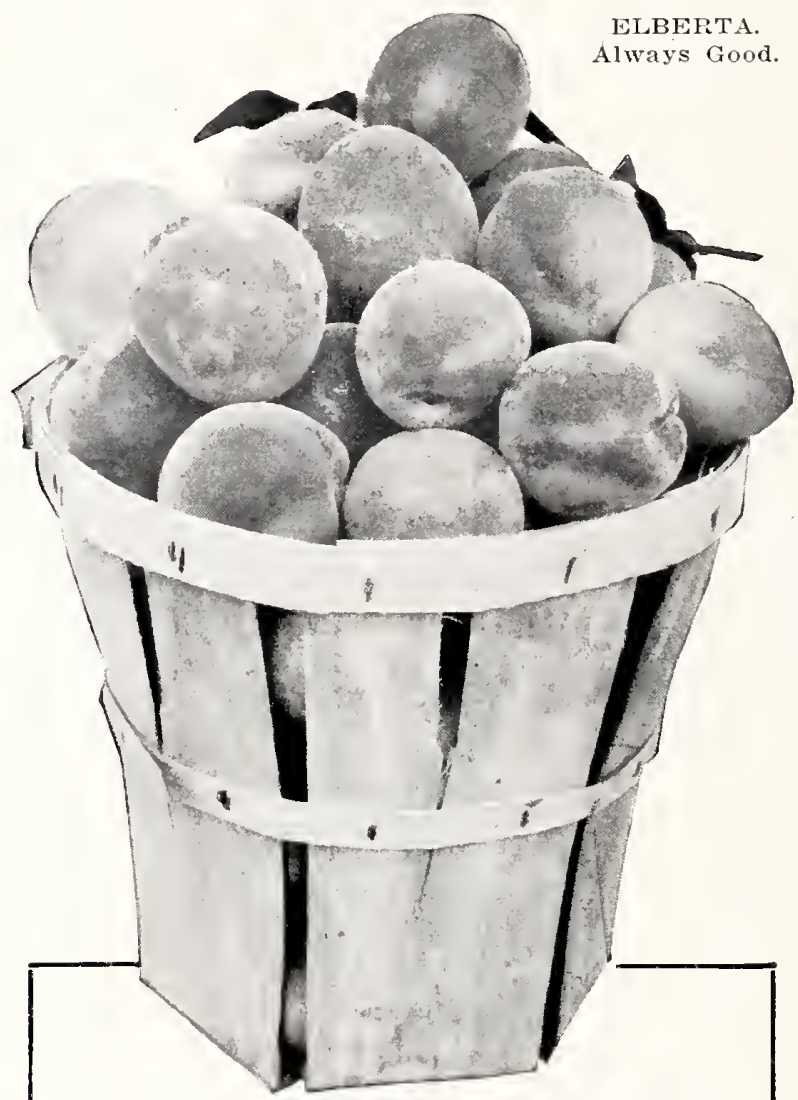

PLANTING and CARE

The peach is the quickest maturing of fruit trees, often bearing the second year after trans planting. Plant only in well drained soil but otherwise follow methods recommended for other fruit trees, see page 41 .

At pruning time prune very severely removing all side branches to short stubs and head low. The peach tree gets top heavy if allowed to develop a high head.

Subsequent orchard pruning consists of shortening in the terminal growth and generally keeping the tree compact and shapely. A bulletin "How to Prune" all fruit trees will be sent on request. Spray Bulletin likewise availabe.

The borer which hibernates right below the trunk should be removed annually. A new chemical Pala-di-chlorobenzine may be used to chemical Para-di-chlorobenzine may contol this pest. Our orchard growing and nurite us your cuestions and we will try to help you.

Check up on your peach trees this year. If they need renewing, order now. 


\section{CHERRIES Seldom Fail to Bear}

PRLANTING INS'IRUCTIONS

Cherries will not grow on any but well drained soil. The sweet varieties are failures unless they are favorably located The May or Sour varieties are the most dependable ploducing heavy crops at an early age.

Be very sure to press the soil very firmly about the roots and put them in promptly on arrival. It is the most difficult of fruit trees to transplant Prune in the same way as apple ol pear except that the central leader is left practically undisturbed. spraying to prevent wormy fruit is seldom necessary and leaf spot on the foliage can be controlled by Bordeaux Mixture. Bulletin covering Avoid excessive pruning of established trees.

\section{PRI CES:}

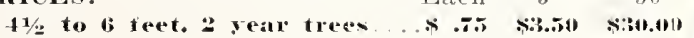

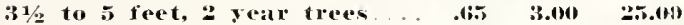

\section{Cluster and Sub-Acid Cherries}

The varieties listed in this group have prover best adapted to this section of the country. You may plant any one of these varieties and you will be rewarded. This group seldom fails to bear ? good crop.

Early Tichmond. This old standard cherry has been the favorite for a number of years. In quality it is tart and very valuable for canning purposes. It yields nearly every year and reddens the tree with its wonderful crop. It succeeds everywhere cherries will grow and as it is the earliest in season of bearing it is very popular.

May Duke. This ripens a little earlier than the preceding variety and while not quite so vigorous in tree, the fruit is slightly superior. It is an old variety and has been tested and
a place in all cherry plantings.

Ioutuoreucy. This is gradually supplanting the Early Fichmond principally, because of its size. It resembles Richmond very closely and except fol being a little later the descriptions are practically the same. This variety is not quite as acid as others of its group and when ripe is good to eat from hand. The tree is hardy blooming late and will make a crop frequently when the sweet varieties fail.

\section{Sweets or "Heart"}

This group grows luxuriantly, makes a fine showing for a few years, and then if not in soil that is exactly suitable, will die. These varieties are the haldiest of the group.

Black Tartarian. This old-fashioned variety is today perhaps the most popular of the sweet varieties. The fruit is large, black and heart-shaped. In quality it is rich. The tree is
be overlooked.

Governor Wood. This is another variety that has been eataloged for a number of years and to date we find few that are superior to it in quality or productiveness. It is a pale yellow with blush; fruit medium sized and flesl soft and of good quality, making it a most valuable table cherry.

Iellow Spanish. This is a later variety than any of the preceding. Its large yellow, firm and high-qualitied fruit has made it exceedingly popular around the whole world. It is not quite as tender as some of the preceding and its fruit can be adapted to a multitude of uses. Not planted as it should be.

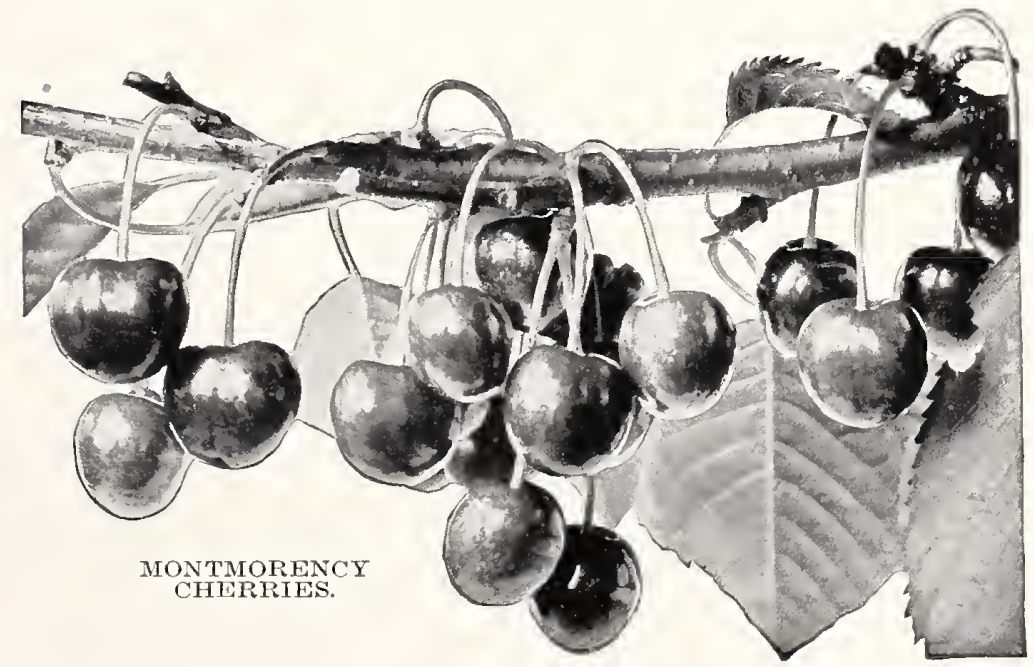

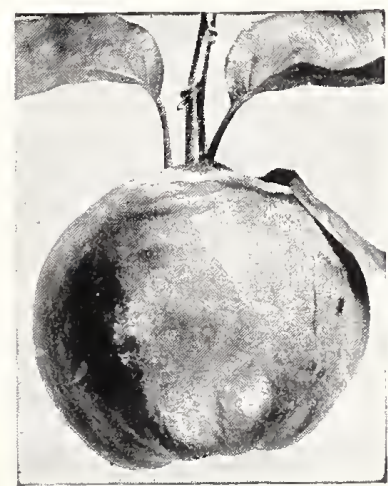

ORANGE OUINCE.

QUINCE

The quince. Luxuriates in good deep ground, and on such will quickly yield an abundance of fruit just the best to preserve or for jelly. We have tried all the standard kinds. but the Orange las been by far the best for us.

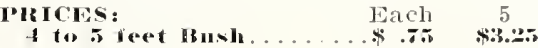

\section{APRICOTS}

Ipricors. This well known fruit has been regarded as semi-tender and hardy able to bear our Kentucky vinters. We have secured a variety that is as hardy as the Peach and is that is as hardy as the peach and reasonably sure to bear a heavy crop ouality unexcelled and most desirQuality unexcelled and

PItICES:

Each 5

5 to 6 feet.............

HIS NOW WHIJA PIHICS IRL LOWLST IS INAMS.

What is better than fresh cherry pie with the cherries from your own garden? 


\section{DELICIOUS PEARS -}

Plant and prune as you would apple trees. Orerstimulation invites bligh hich is the fruit"s greatest enemy and his cannot be profitably controlled

Eulopean Pear's (E) ale finest for quality, but the Japanese (J) are the inost plolific.

\section{PIICI:S:}

11/2 to di rect. 2 veal trees

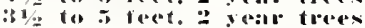

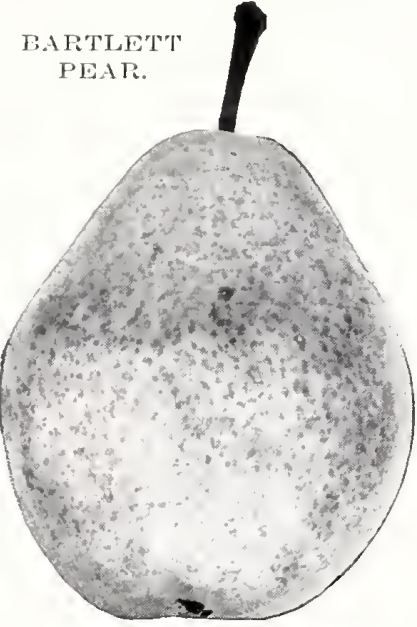

$\begin{array}{ccc}\text { Each } & 5 & 50 \\ \times .75 & \$ 3.50 & \$ \$ 0.100\end{array}$

Injou. (E). Large, buttery and melting. Best fall pear, lieeping well. September.

Hartlett. (E). August 15. This is no doubt he favorite eating pear offeled today. It In quality it has no equal. "The tree bears larity everywhere it is the most sought after of the European pears.

Clan's Favorite. (E). August 1st. This is a seedling of Bartlett and earlier ripening. it is lemon yellow in color with brown dots. In quality it is almost the equal of

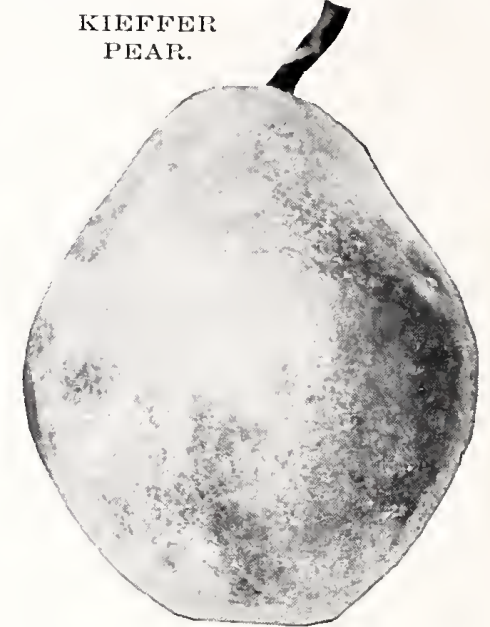

liener. (J). September 10-15. This today is the most popular pear for onl sec. tion. The fruit is a large golden yellow sometimes tinted red on the sull tx posed side. The hesh is vely firm, crisp and juicy, and for canning pulposes it 1s especially prized. From the tree it is not good to eat, and to properiy ripen, gather carefully and place in quality improves and it is then desirable. For keeping longer, pack in shallow ti"a $o r^{*}$ wap the fruit in paper and store in a room frequently kept until Christmas in this manner.

Seckel (E). September 15. This small high-quality yellowish-brown peal is one of the most popular of the September fruits. Of melting juicy and sugary quality (frequently called the little sugar pear), makes it one of the most popular varieties. The tree is of slow growth.

\section{PLUMS Ornamental as well as useful}

Plums are quicli glowing. eally maturing, and one of the most profitable of tree fruits. May be planted in the sod, chicken run or anywhere there is good soil.

Plant and prune as you would other fruit trees, see page 41. Plums are inclined to overbear and should be thinned so they will not touch. This prevents rot alld incleases size of fruit. Troubled sometimes will tlie
boler, treat in the same way as you would nercll trees. (E) indicates European, (A) American and (J) Japanese plums.

PIIICES:

11/2 to di feet, a year trees

$31 / 2$ to 5 reet. 2 pear trees

Each 5050

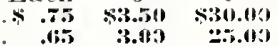

clumdance. (J). July. One of the best and hardiest of the Japanese varieties. Fruit is large oval, and in good and the tree is haldy. One of the best.

Burlouk. (J). Late July. A later, more vigorous valiety than the preceding. In color, violet to light purple with occasional shades of yellow. Fruit is large, flesh yelmarketing this is the most popular solt. We believe it to be the hardiest and most prolific of the Japallese varieties.

Isınsou. (E). This variety has been a standard for yerats and is really too well known to describe. Trees ale upright in character of growth and usually bear great plums will grow.

Nulieott. (Hybrid). This is a new hybrid that will no doubt prove a valuable addition to our list of varieties. The tree is one of the most vigorous. It seems to be absolutely free from disease and bears a great crop of fruit, amber in color and of excellent quality.

Green Gage. (E). Another old variety that has been outstanding for a number of yeals. It ripens in mid-

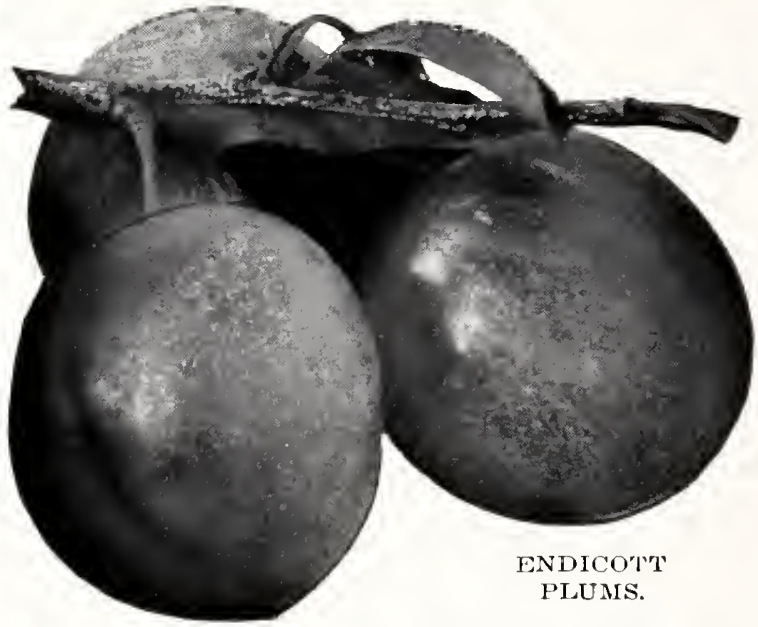

ity fruit makes it a standard of excellence by which the other's are judged. The tree is a moderate grower but healthy.

Omilha. (Hybrid). This is another very promising valiety being vigorous in growth and free from disease. Being an American-Japanese hybrid, it inherits the hardiness and productiveness from each parent and produces great crops of coral
fruit that is yellow fleshed and of good quality.

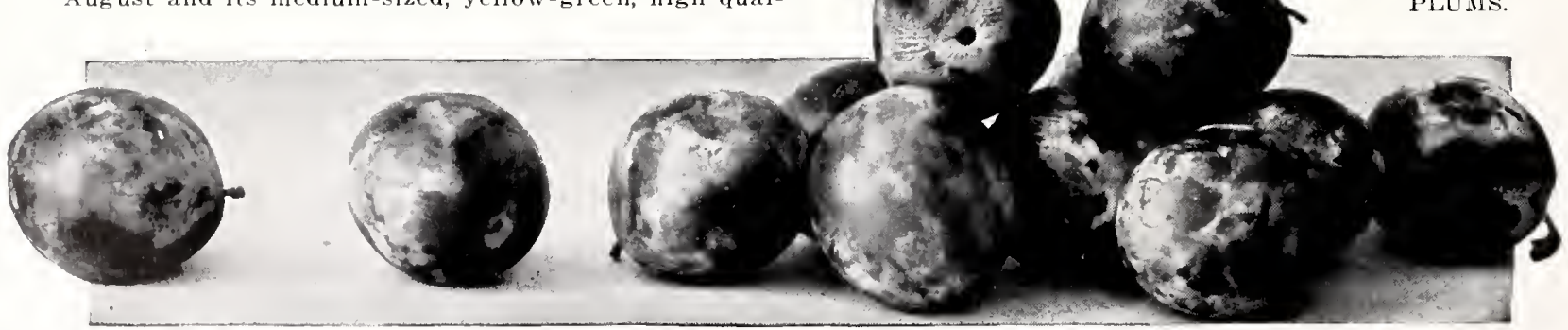

We ship at the right time to plant. Free planting booklet with every order. 


\section{GRAPES - - The Best Home Fruit}

\section{Easy to Grow, Abundant in Yield, Very Ornamental.} No Home Should be Without a few Varieties

$\mathrm{D}$

YOU remember a complete failure of your grape crop? No fruit demands less attention, less space and bears as regularly and abundantly. Ordinary good soil, a fleck of sunshine, and frequent annual pruning of a very severe nature, spells success with grapes.

PRICES: 2 year old vines. 25e each; 10 for By Parcel P'ost add $10 \%$.

\section{Black Grapes}

Concoril. This is without doubt the best general purpose grape grown. Its planting perhaps equals all the other varieties combined. Berry large. Bunches shouldered and compact. This variety, we believe, should be the "backbone" of your planting. Special prices on large quantities.

Moore's Early. An extra early variety. Mi ed i u bunch, large berry and hardy. Is very reliable and does well wherever planted.

Worden. A seedling of Concord, better quality. Ripens ten days earlier. Bunch and berry large, compact. Not quite so hardy or long-lived: however, it should be planted in every collection.

\section{Red Grapes}

Asavam. Has loose bunches of dull red color, superior in quality. Skin fleshy but flavor unusually fine. Keeps late.

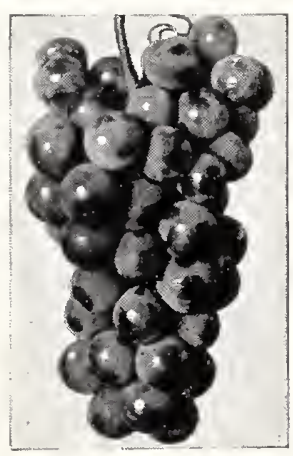

WORDEN
Hrimlon. Larre, compact, shouldered bunch, wit h medium to large berry; juicy, sweet. Unsurpassed for table.

caco. A new amber red variety of unusual promise. It is a cross between Catawba and Concord and is different $t h$ a $n$ either parent. Vine is vigorous and bears very early. Its flavor is distinctive, sweet and delightful.

Catawh. Standard late red

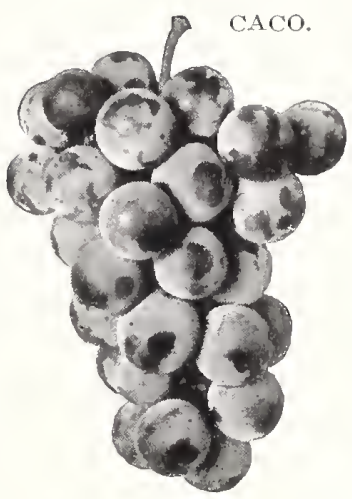
grape that has lost none of its popularity. Season and quality make it indispensable.

Delaware. A well known red grape. Bunch and berry small, compret. Flavor unsurpassed. Not a strong grower; must be given good, rich soil.

Lindley. Of exceptionally good quality, large; ripening in midseason. Vigorous of vine, and haldy.

Incille. A new grape of decided merit. Very hardy. Likely to overbear if not pruned severely. Bunches very compact, color light red.

Lutic. An early grape of good size. Its popularity makes the vines scarce. Best extra early.

Wyomins. Bunch and berry small but perfect. A hardy, productive variety of excellent quality.

\section{White Grapes}

M:ıtli:ı. An old standard white grape of merit.

Niagar:. The best white grape; bunch and berry large, meaty and juicy; flavor perfect. Well known.

\section{How to Plant and Care for Grapes}

Plant in full sunlight, eight feet apart, placing the roots in a trench or long hole (not round) and about eight inches deep. Turn the roots one way and cover all except two or three buds. Turning the vines all one way, each vine has the same feeding radius and stakes same reeding radius and stakes nay be removed vine back to two buds and donting prune the two vigorous canes develop. Remove all others.

The secret of grape production is in annua pruning and unless the first year's growth is vigorous, cut it back to the ground and let it come the second year in two or three vigorous canes and keep them tied up as vines grow more rapidly when kept off the ground. The graphic shows an old vine properly trained and pruned. The general rule is to leave a spur every fifteen inches along the cane, being sure that it is a vigorous one. Cut away all the tops save three to five "eyes" completely removing all weak growth. "Arms" or longer growth may be left instead of many short spurs but in all events prune severely and every year.

Black Rot is the greatest pest and if sprayed with Bordeaux Mixture when the grapes ale the size of small shot and repeated until the seeds get hard, it is easily controlled. Should your leaves in the spring be punctured by the grape beetle, Arsenate of Lead in standard strength is advised.

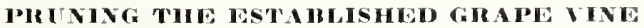
In the illustration below note the marlis showing how the canes are annually pruned to three to five buds distributed along the vine.
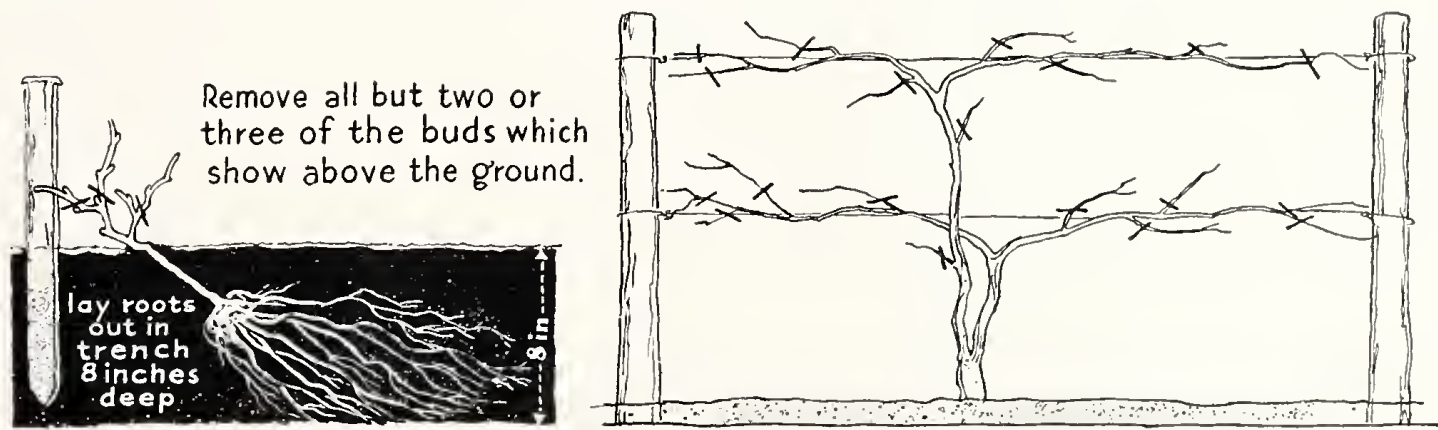

The best place to buy fruits is direct from the nurseryman who grows them. 


\section{SMALL FRUITS -}

\section{Currants and Gooseberries}

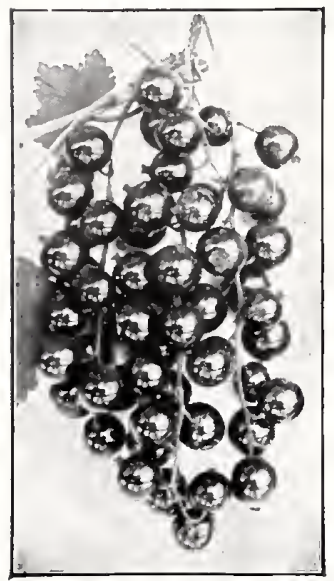

RED DUTCH

CURRANT.

\section{ORDER}

EARLY

It is to your advantage to order early while our stocks a $\mathrm{r}$ e full. Orders first received a $r$ e first filled We ship at the right time.
CRRANTS and gooseberries grow
best in garden soil. With little care
they produce great crops of fruit.

CAlis: The same care may be given both. Plant three to six feet apart, so as to allow plenty of space. Prune to within six inches of ground at planting time. When plants get old, "sneak out" the dead wood canes that are losing their vigor, and thus encourage new growth.

About the only pest to molest them is a green worm that eats the foliage. A dusting of the plants with arsenate of lead will control this. If mildew appears, Bordeaux mixture or Lime Sulphur will control it.

Hed Duteh Currant. By far the most productive of the many kinds we have berries Color of fruit a brilliant red, large stems and quality is excellent. The white varieties have proven worthless in this climate.

Downing Gooseberry. Fruit almost round, large, and juicy. Best quality. Whitish green color. Does especially well in the green

Houghton Gooseberry. Round, dark red when ripe; juicy, sweet. Thin, smooth slin. Medium size. The bush is hardy, the best for general purpose in this secthe best for general purpose in this sec

PPICES: Each $5 \quad 10$ By post add $10 \% \ldots \ldots . \$ 25 \quad \$ 1.00 \quad \$ 2.00$

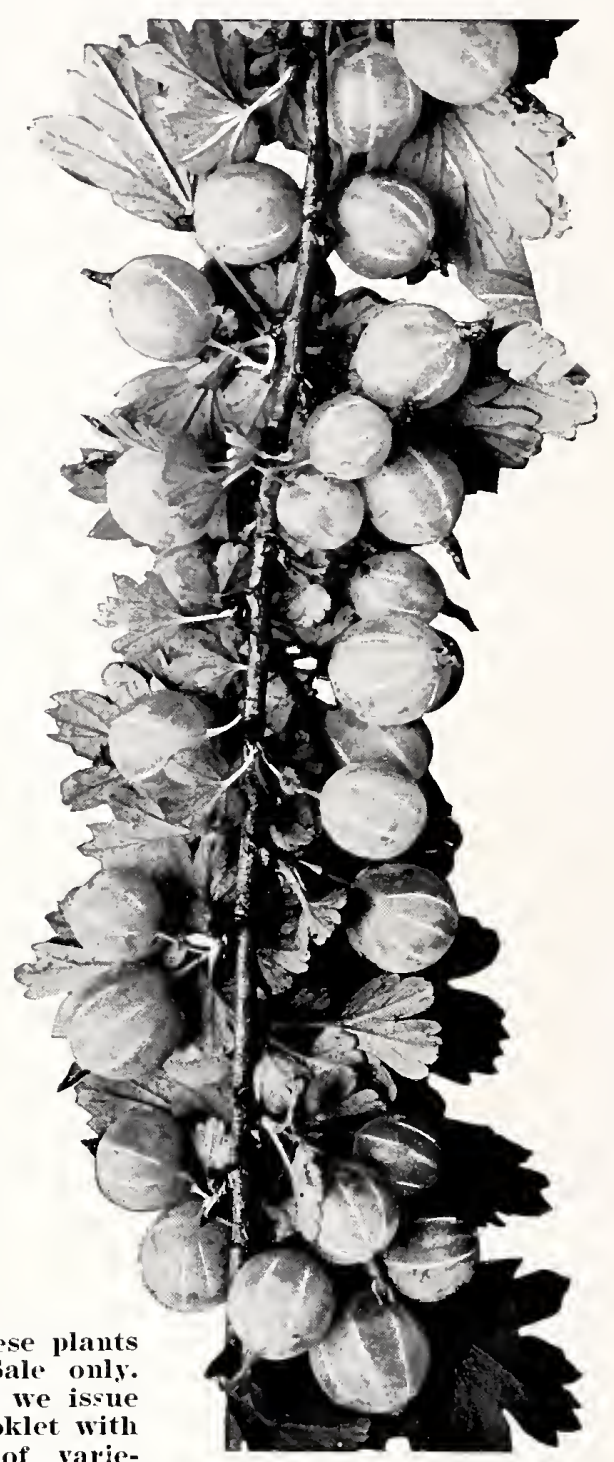

1:OWNTNG GOOSEBERRY.

\section{STRAWBERRIES}

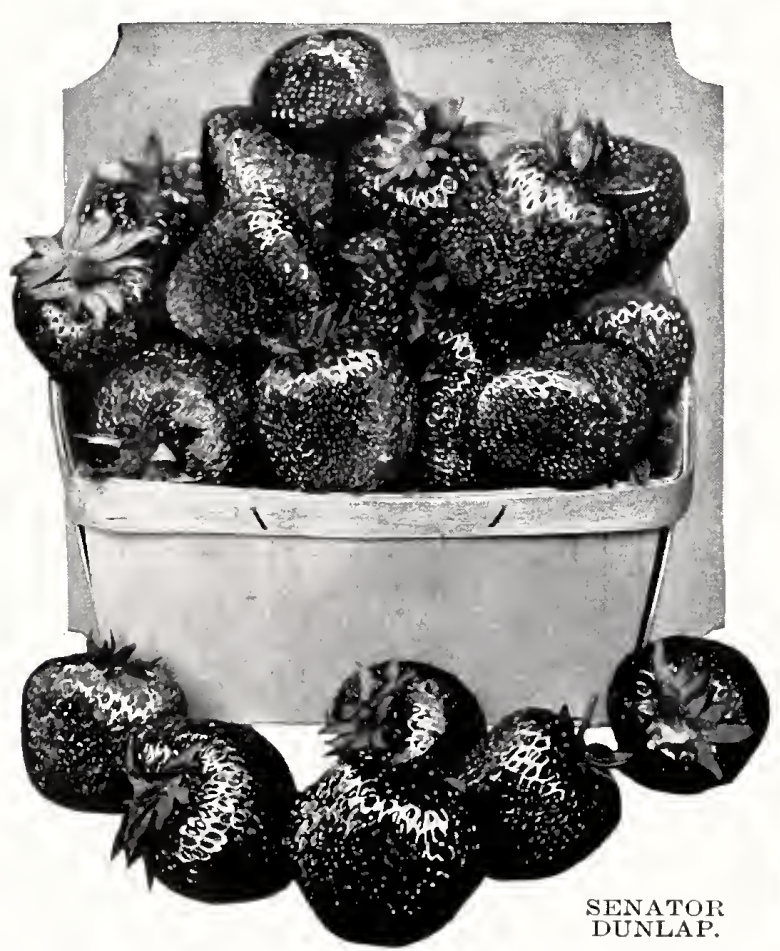

We list these plants for Spring Sale only. It that time we issue a Special Booklet witl ties telling you how to plant, cultivate a 11

care for them. We shall be pleased to mail you a copy when ready, if requested.

Spring planting only is advised. They heave out of the ground when planted in the fall. Orders placed now for strawberry plants will be shipped and billed in the spring at the correct planting time. You can depend on us to do this for you. The plant crop is not anticipated to be a large one. Order early.

\section{VARIETIES}

Aroma...........Mid-season.......Big dark red berries Gandy ...................... old standby very popular Senator Dunlap...Early mid-season..... The old reliable

\begin{tabular}{|c|} 
CULTURAL HINTS \\
Small fruits bear first year after planting and \\
are good for several crops when properly cared for. \\
They are almost indispensible in the home garden. \\
If you will follow our instructions after receiving \\
planting you will be successful. \\
Intercropping a young orchard that is, planting \\
it witl vegetables or small fruits, is a good way \\
to utilize ground and cultivate the trees. \\
We suggest to those who purchase fruit trees \\
that there is no diffeulty in practicing deceptions, \\
as it takes a tree several years to bear. You should \\
buy only from reliable sources.
\end{tabular}

If you have no further use for this catalog, give it to a friend, please. 


\section{RASPBERRIES and BLACKBERRIES}

\section{Put your waste spaces to work growing berries}

$\mathrm{R}$ ASPBERRIES and blackberries succeed in about the same type of soil. Partial shade is no hindrance, as they grow naturally in the edges of woods as well as in open exposures. They may be planted along fences. between orchard rows or in the garden. Watch them thrive.

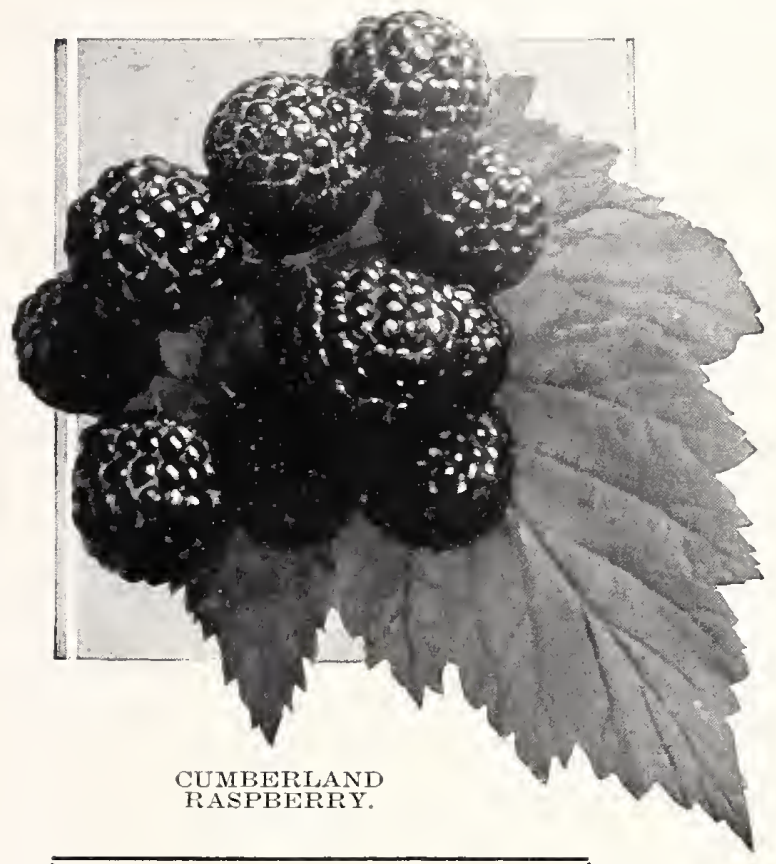

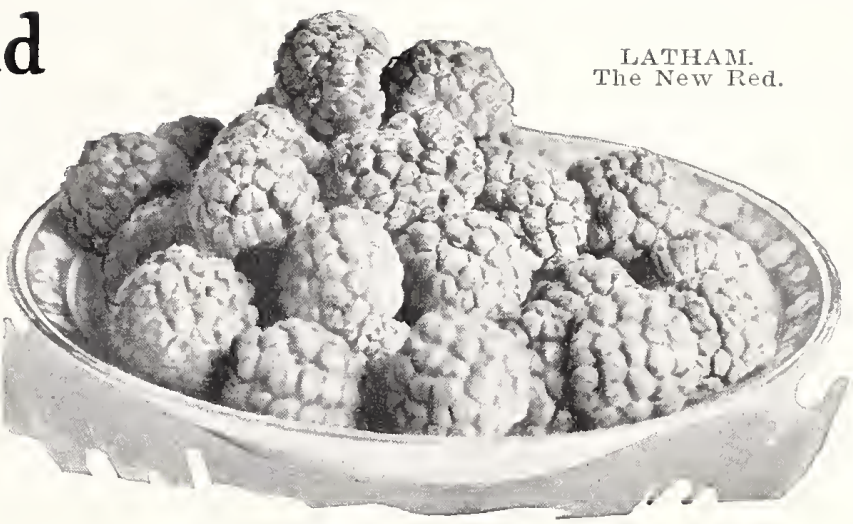

RED RASPBERRIES

LATHAM-The New Red

Luthm. This variety has had its test and anyone planting Red Raspberries should by all means set it. Not only is it vigorous in growth, throwing large heavy canes on strong ground but its foliage is the most vigorous. It thus matures its wood to the very tip. winters admirably and in the spring blossoms out to the very tips. The fruit is twice as lorge as some of the ther raspberries and of the as large as some of the other raspberies and of the finest quality. "The color is a clear pink and more pleasing than the purplish varieties so much boosted. growing as a commercial practice.

Cuthbert. Crimson, large, conical, firm and juicy. The canes are upright, strong and vigorous. Hardy. The standard late red market and home variety that is so popular and unsurpassed.

St. Regis. This so-called "ever-bearing" does produce some berries throughout the summer, and in the spring is all excellent producer. Quality very good.

\section{BLACK RASPBERRIES}

Cumberland. This is decidedly the best black raspberry be ing comparatively free of disease and much more prolific than any other of the black cap varieties. It makes a strong vigorous cane, should be given plenty of space and produces a fine crop of large, jet black, juicy beries that haven't the red seeds in them like many linds. We standing it is an old variety.

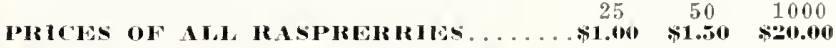
sold only in bundles of 25 . Hy Post, ald $10 \%$ for postage.

\section{BLACKBERRIES}

Planting and After-Care

Prepare your ground as you rows with small vegetables, open space plants two and a lialf to three and a half feet apart. The rows should be five feet or wider. Plant about four to five inches deep, and cut off tops three inches above the ground.

As they grow older do not allow too many canes to develop. rather just a few strong canes. Pinch out the tops of these, when the tips are soft. Should you prefer to train on wires or stakes, thin out the plants to four canes and allow tops to develop naturally.

The brambles are perennials whose old wood dies after pro-
ducing one crop. This wood should be removed as soon as through fruiting. These plants have no particular insect enemies.

IAWN SEED - Genuine Kentucky grown blue grass seed, best for lawns. It pays to use good seed. See page 40 .
Eldorado. Here is a blackberry that has stood at the head of the list for many years and its position still is not in danger. It is later ject to disease, and makes heavy vigorous canes that hold the leaves and fruit well. Given a favorable season with moisture or grown under mulch it ploduces very large. long fruits that are a pride and joy to the grower. Plant in confidence.

Early Harvest. Extra earliness and productiveness make this the leading commercial and home variety. Is through with its crop when the wild ones begin to ripen. Hangs well onto the canes and is a money malier.

PISICHS:

$25-50-1000$ Sold onts in but \$1.016 \$1.50 \$25.610 if by Parcel Post.

\section{DEWBERRY}

We consider Lucretia the best Dewberry making a very vigorous growth, fruiting early. The berries are large jet black and of fine flavor. May be allowed to develop on the ground or trained, in either case producing large crops.

$\begin{array}{ccc}25 & 50 & 1000\end{array}$

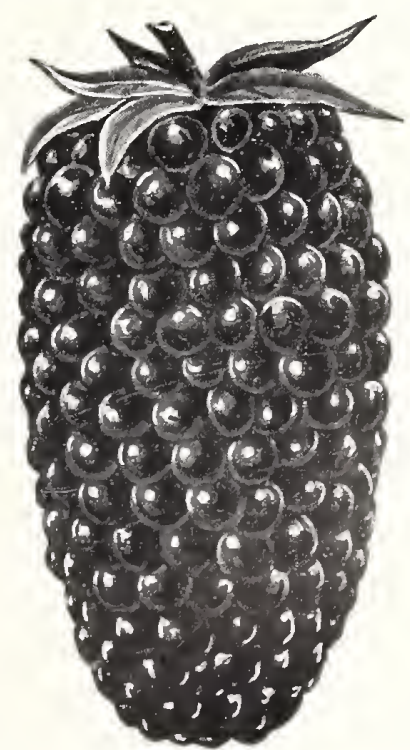

ELDORADO

We have no agents. For Hillenmeyer quality and service, buy direct from Hillenmeyer's. Use the order blank. 


\section{Grow your own ASPARAGUS --It's easy}

A

SPARAGUS is the earliest and best of all esculents and is the easiest to grow, if many old icleas ale discalded. It is one of the most persistent of plants-tough as dock, but even dock can be killed over the same lines that cause people to fail with asparagus. There are two ways to grow asparagus. The ownel of a town lot needs a bed five feet wide and as long as he wishes. Let it be made cream rich. spaded over, and then have three rows eighteen inches apart drawn through it with a six-inch hoe. The rows should be about four inches deep. Then the crowns should be spread out in these just as mucl like a spider as possible. Then let the earth be raked over and let th's bed be kept clean, free from weeds, and well manuled for all time.

The gardenel, with a plow and ample ground, can do better. Let him lay off rows five ol six feet wide, and plant and manage just as indicated. After two years growth, the town man must fork over his bed, but the farmer can just cut the earth from the rows and turn it back. The old idea was to set the roots a foot deep, so that the shoots might be long and white. The new idea is to let the plant grow like any other and then mound over the crown when the shoots are wanted otherwise than nature intended, and at the end of that time to plow the
There is no vegetable more delicious or more healthful than fresh asparagus

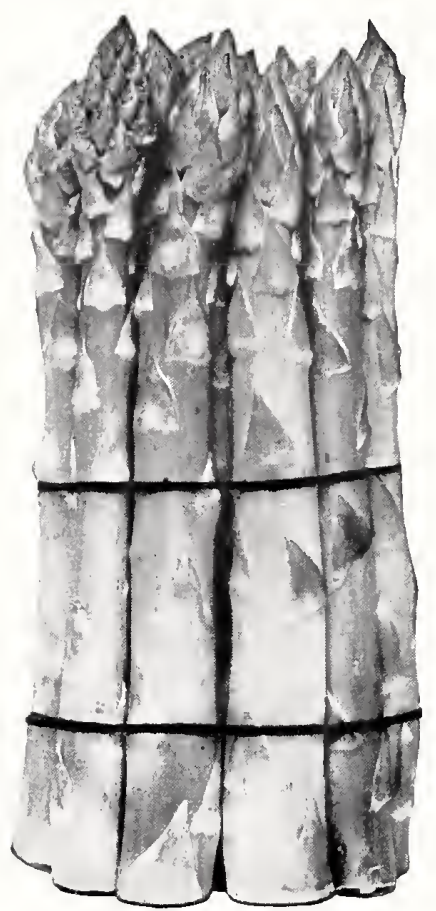

soil and restore normal conditions. This can be done by the larger grower, but the town man can only keep more manure and force the plant to make a new tier of roots nearer the surface. Asparagus wants to be near the surface like any other plant, and if we will heap the earth over them for a long time and then remove it when sluoots long, white and tender are no longer needed. grandchildren will bless the hand that planted. The things that cause failure are: Planting near trees or vines, the covering of plants so deep that resurrection is impossible, the nowing of tops when green, the covering with salt and rioting of weeds. Moles do not injure; no pit is needed nor wall of stone, but only the practice suggested. There are thousands of beds ruined by some of these malpractices mentioned, for which nothing can be done except to plant a new bed and treat the old in the meantime with ordinary plant prudence. The plants may be set with equal certainty either fall or spring.

Martha Washington. This is the new variety of asparagus that seems destined to succeed the older kinds. It is very vigorous and "rust proof" which disease has wrought havoc with many beds. The tips are large very fine in texture and white in ing this variety.

PIICES: $\quad 50 \quad 100 \quad 1000$

¿r. Plants.....\$1.00 \$1.50 \$10.00 By Post Iid $10 \%$ Extra

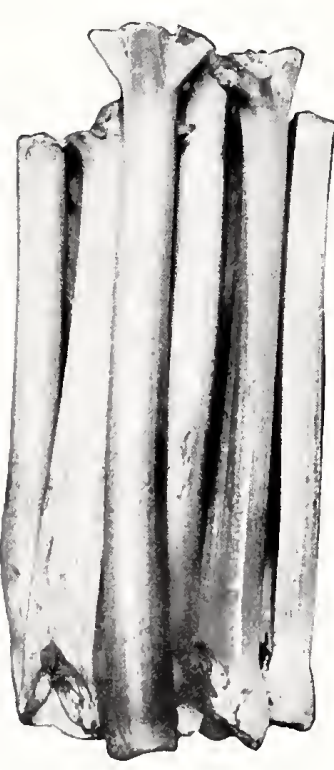

\section{RHUBARB}

Rhubarb or pie plant is known to every one.

Planted $4 \times 3$ feet with eye 4 inches below the surface on clean soil, success is assured. We offer only divided crown and not seedling plants as these are worthless.

Excelsior. Very early with long stem. Plant vigorous and dependable.

IRICLS: Ea. 5100 $\begin{array}{lll}.10 & .50 & \$ 8.00\end{array}$ If by lost, add $10 \%$ extra

We prefer not to fill orders for less than $\$ 1.00$. Please note.

\section{GRASS SEED}

Located in the center of the Blue Grass country we are able to furnisl the finest seed obtainable. Order fresh new seed every year. See page 40 .

\section{SEED POTATOES}

At the time this catalog is being printed our Second Crop irish Cobbler potatoes are looking especially fine. We are making a specialty of CERTIFIED SEED POTATOES and in the winter we will have out a special bulletin offering these at market prices. If you are going to plant potatoes this spring do not fail to let us quote you on your requirements. Our seed is acknowledged to be superior.

\section{YOUR ORDER SHIPPED at the RIGHT TIME}

We book orders throughout the entire year with the understanding that they will be sent at the proper time. In no case will we send an order out that we feel will not do well because of being "out of season". In every case we will advise you when shipment is made. When plants have not been sufficiently matured by frost, when the ground is too cold, or plants too tender, we will use our judgment as to shipping time. This relieves you of worry and care of plants until proper planting conditions arrive. You can order early with confidence of receiving plants at the correct planting time. 


\section{OUR LIBERAL TERMS Read Before Ordering}

YASH with order is expected. When credit must be arranged please write us in ample time.

Charges for packing are made on all orders not paid for at time of shipment. This amounts to between five and ten per cent.

IMLIVEIX-Of course, we deliver without extra charge in Lexington and nearby suburbs.

Quite a lot of stock can be economically delivered by truck to nearby communities. We will be pleased to make arrangements for this service at prevailing rates. Delivery by truck insures safe and prompt arrival, and stock invariably reaches the purchaser in better condition.

We guarantee the safe arrival of all goods sent by us whether express, freight or parcel post. This guarantee is made with the distinct understanding that unfavorable reports be made within three days and only after proper notation is made on trans portation company's delivery ticket if damaged packages are received.

PARCEL POST-The postal limitations of size and weight make it impractical to send heavy orders this way but we ship this way wherever possible. We make a flat charge of ten per cent to cover the postage. We expect you to send postage with your order if it is to come to you by parcel post. We will appreciate receiving the ten per cent amount.

ERRORS-We do make errors in the rusl of shipping season. We will make them good if advised promptly on receipt of order, and will appreciate your co-operation in this respect. Delay in so advising makes it impractical to check the faulty handling and this makes adjustments all the more difficult.

GUARANTEE TO GROW-At prices we sell stock, it is not guaranteed to grow. We do guarantee it to be first class stock and to reach you in good condition. In case it is not, if you will advise, we will adjust any claim. Unfavorable weather, poor soil, failure to prune properly, improper

planting, and other things may cause even the healthiest plant to die and, of course, we cannot guarantee against all those conditions, when a combination or any one of them may cause failure.

TRUE TO NAML-We expect to deliver every plant true to name and description and if any plant proves untrue we will replace with another of the right kind or refund the purchase price. Beyond this we do not assume any liability. However, our replacements are negligible as we exercise the ntmost care in planting, propagating, digging and keeping our plants true to name.

SUBSTITUTIONS-Sometimes we do liun out of a variety and take the liberty of substituting unless advised by the patron "No Substitutions." Frequently we are able to improve selections but do not attempt changing a list without instruction. In all cases when substitution is made we will mark the labels correctly.

AGENTS - We have no fight against those doing honest business but we have NO AGENTS out representing our organization. Our responsibility is direct to the customer. Annually we are misrepresented by tree peddlers and agents who have no responsibility whatever.

\section{FEED YOUR PLANTS WITH FERTILIZERS}

\section{BONL MEAL}

A fertilizer for all purposes being safe and effective. No danger of burning the foliage or doing root injury when using this. Fine for lawns, too, requiring $10 \mathrm{lbs}$. to 250 square feet. When in doubt of what to use try Bone Meal for safety and results.

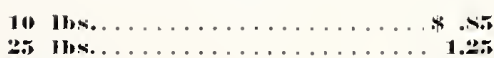

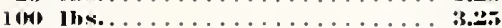

\section{VIGOHO}

A specially prepared plant food containing all the elements necessary to grow flowers, lawns, shrubs or vegetables. Can be sown like grass seed and is clean and odorless. A nationally known product that is giving excellent results. It is inexpensive, costing from $10 \mathrm{c}$ to $20 \mathrm{c}$ for each 100 square feet. Apply 4 lbs. over this area in spring and Fall. complete direc10 lb.s. tions in every bag.

ito ins.

$\$ 1.001$

1140 lbs.

i.7.

\section{PEAT MOSS}

Is a brown colored virgin soil rormed by the decay of moss and ease weed seed and is perhaps the best "soil conditioner" ever discovered. A bale will cover 300 quare feet one inch deep. May paded in. A leaflet describing its many uses is available. Per bale................10

\section{SHEEP MANURE (Pulverized)} The standard animal manure, quickest to give results and can be alpplied as a top dressing without fear of injury. Results are immediate and application should be made two or three times per year. Equally le used daily in safety in liquid form if necessary using $1 \mathrm{lb}$. to 5 111 llow.

iii) ins. gallons of water

SULFATE OF AMMONIA

Used for its nitrogen. A very effective fertilizer for all plants in which a large leaf development or rapid growth is desiled. Tends to create an acid re-action on soil. "Water in" after applying. 1 lb. to 50 square feet is recommended. Use in very weak solution on newly set plants.

11) Hos.

בIII IIs.

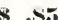

IIII) HI.:. $1 . .70$

We have satisfied thousands and thousands of customers in our 89 years of service. 


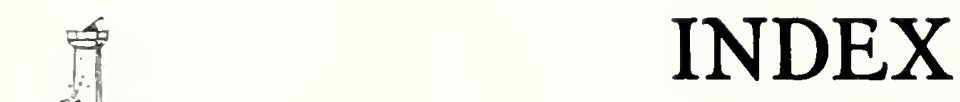

Page

Abelia.........., 19, 23

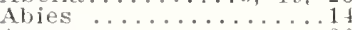

Acer

Adam's Needle..........

Allspice .................

Almond Flowering....

Ampelopsis $\ldots \ldots \ldots \ldots \ldots 35$

Anchusa $\ldots \ldots \ldots \ldots \ldots \ldots . .34$

Anemone ........... $42-43$

Apricots $\ldots \ldots \ldots \ldots \ldots \ldots+45$

Aralia

Arbor vitae ..........

Arbutus, Bush.....19, 25

Arrow viood ..........

Arundo $\ldots \ldots \ldots \ldots \ldots 22,26$

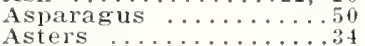

Astilbe $\ldots \ldots \ldots \ldots \ldots \ldots . \ldots 44$

\section{B}

Baby's Breath ......34 Baptisia ...6. 192534 Beard Tongue.......... Beautyberry ….... 6 Beauty Bush $\ldots \ldots \ldots \ldots 2$ Benzoin ............ Berberis ....6, $19,25,32$ Betula ............21, 28

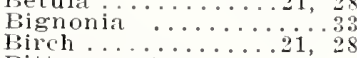
Bittersweet ............. Blackberries .......... Blanket Flower ......35 Bleeding Heart $\ldots \ldots \ldots 34$
Boston Ivy $\ldots \ldots \ldots \ldots$ Boxton 1vy $\ldots \ldots \ldots \ldots \ldots . .19$ Broad-leaved EverBridal wreath .......

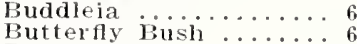
Butterfly Bush ....... 6
Buxus ..........

\section{C}

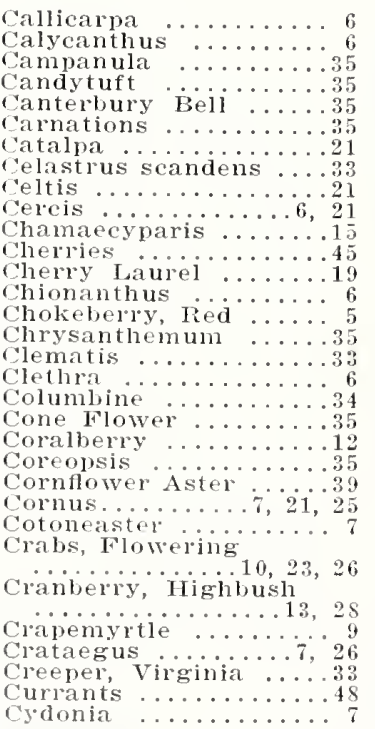

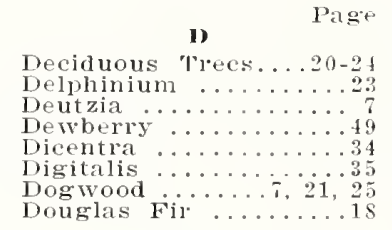

Elder .............. 1 I Elaeagnus …2.24, $26,2 \frac{7}{7}$ Eulalia …… Euonymus...8, $19,26,33$
Evening Primiose . . Evergreens ......
Exocholda.. .19

\section{F}

False Indigo .........34 Flax $\ldots$. Fing Aimond.... Flowering Cherry $\ldots \ldots 23$ Flowering Crab.10, 23,26
Flowering Dogwood. 25 Flowering Peach.

Flowering Quince.

Flowering Thorns

Firethorn

Forsythia .......8, 26

Foxglove $\ldots \ldots \ldots \ldots \ldots 35$

Fruit Department...41-49

Funkia partment...41-49

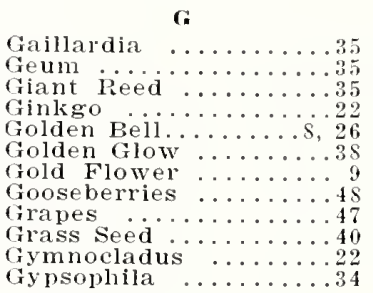

Gymnocladus $\ldots \ldots \ldots 22$
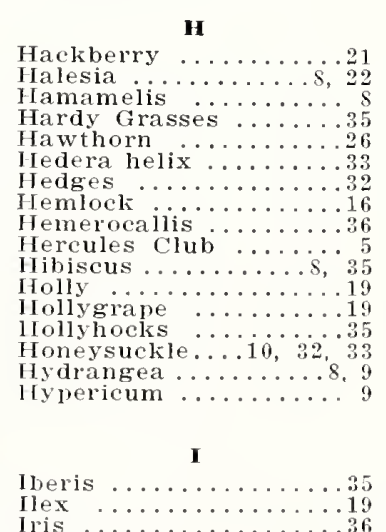

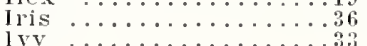

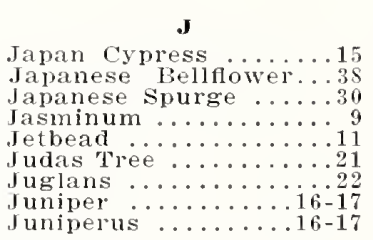

k Page

Kentucky Coffee Tree. 22 Kerita

Koelreuteria

Kolkwitzia $\ldots \ldots \ldots \ldots \ldots 27$
Kudzu $\ldots \ldots \ldots \ldots \ldots$

\section{I.}

Lagerstroemia

Larkspur

Lathyus ....

Laurocerasus ..................

Lemon Lily ........36

Lespedeza ......... 9

Ligustrum ........ 32

Lilac

Linden

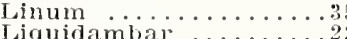

liriodendron..$\ldots \ldots \ldots 22$

Locust ........ I0, 32,31

\section{$\mathbf{M}$}

Magnolia ......10, 23, 27 Mahonia............. 10, 19 Maiden Hair......... Mallow Marrels........ 30,235 Malus .......

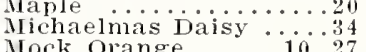
Mock Orange......10, 27 lulberry ...........23

\section{$\mathbf{N}$
Ninebark $\ldots \ldots \ldots \ldots \ldots 11$}

Oak $\quad$ o

Genothera $\ldots \ldots . . .24$

Ornamental Shrubs. 5-13 Orllamental vines ...

\section{Pachysandra}

Pachysandra ..........36 Painted Daisy .............. Peach, Flowering...... 54 Pearl Bush......... 8 8 Fears $\ldots \ldots \ldots \ldots \ldots \ldots .46$

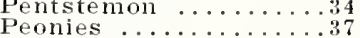
Peonies $\ldots \ldots \ldots \ldots .348$ Periwinlie

Phlox

Philadelphus....... 10,27

Physocarpus.

Picea

Pine

Pinus

Planetree

Plantain Lily

Platanus.

Platycodon

Plums.

Poppies

Populu

Polygonum

Potatoes $\ldots \ldots \ldots . .39$ Priver............ Prunus ......... 11 , $2: 3$ Pseudotsuga $\ldots \ldots \ldots \ldots$ Is Purple Bush ciover.... ? Pussy willow ....... I I Pussy Willow ......

Pyrethrum ..........

Quereus a

Quince ..............

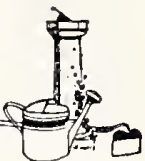

Raspberries ${ }^{\text {It }} . \ldots \ldots \ldots .49$ Raspberries ......... 4 ! Red Hot Poker........ Phodoty pos ............11 Rhubarb $\ldots \ldots \ldots \ldots \ldots 50$ Rhus..........11, 24 Roses.......11, 29, 30,31 Rose of Sharon ...... 8 Rudbeckia $\ldots \ldots \ldots 35,38$
Russian olive....... 7

Salix . . . . .

Salix ........... 24 Scabiosa $\ldots \ldots \ldots \ldots 11$ Sea Lavende ..........

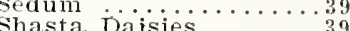
Shasta Daisio Silver Beil............. 22 Silver Lace vine..........33 Snowball .............

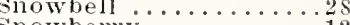
Snowberry $\ldots \ldots \ldots \ldots \ldots 12$ Sorbus G........... Sour Gum .............

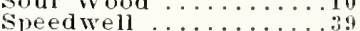

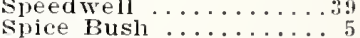
Spice Bush $\ldots \ldots \ldots 12,28,35$ Spluce ............ is

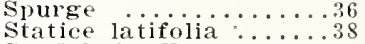
St. John's wort....... 9 Stokesia ............ Stonecrop ..........39 Strawberries .......48 Styrax $\ldots \ldots \ldots \ldots \ldots \ldots \ldots, 28$ Sweetgum .........22 Sweet Pea............39 Sweet Pepper Bush....6

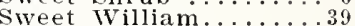

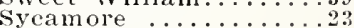
Symphoricarpos ....... Syringa $\ldots \ldots \ldots \ldots \ldots 13$

\section{$\mathbf{T}$}

Tamarix $\ldots \ldots \ldots \ldots \ldots 13$ Taxus $\ldots \ldots \ldots \ldots \ldots$ s Thuja .............14-15 Tilia

Trailing irytle.........

Trees, Deciduous... . $20-24$

Tritoma

Trumpet vine ...........3.

Tufted Pansies .......

Tulip Tree...............

Tlmus......24, 26,27 $\mathbf{V}$

Yarnish Tree.......22

Veronica
Viburnum Vines

Violas $\ldots \ldots \ldots \ldots \ldots \ldots \ldots$

rilginia creeper ........ IV

Wahoo ........... 19

Walnut $\ldots \ldots \ldots \ldots \ldots 22$ Wayfaring rree ...... White Fringe ........ Willow ............. 24 Winterereeper $\ldots \ldots \ldots 33$ Winter Jasmine ........ Wisteria .............

Witch Hazel .........8

Yew $\ldots \ldots \ldots \ldots \ldots 18$ 
REMITTANCE WITH

ORDER, OR C. O. D.

SEE CATALOG.

\section{HILLENMEYER NURSERIES \\ LEXINGTON, KENTUCKY}

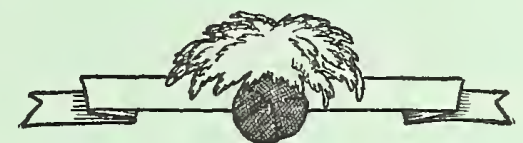

\begin{tabular}{|c|c|}
\hline 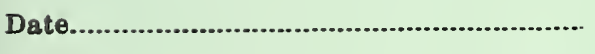 & Forward by \\
\hline
\end{tabular}

NAME $\left\{\begin{array}{l}\text { Mr. } \\ \text { Mrs. } \\ \text { Miss }\end{array}\right\}$

Amount

Enclosed

Check......

Money Order.

Exp. Order... .

Drat. . . . . .

Cash........

stamps......s

Street-Box or Rural Delivery

Ship to if Dif-

ferent from $P$. O

Post Office.

State.

County.

If Out of a Variety, we Sabstitute a Similar kind Unless Notified Otherwise. All orders Subject to Catalog Conditions.

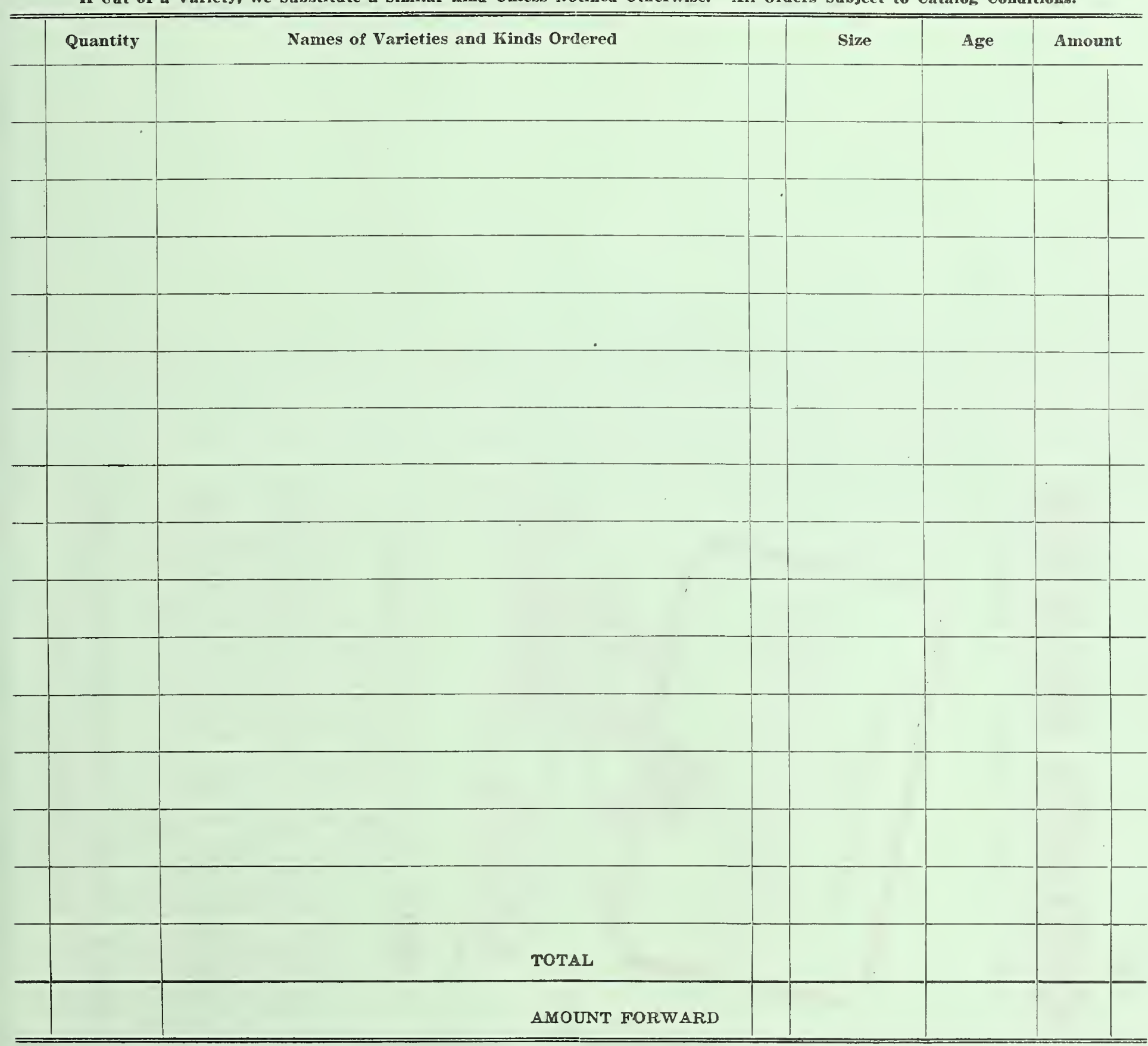


Please Do not Write Anything but Your Order on Order Sheet. Write Letters on a Separate Sheet of Paper

Quantity
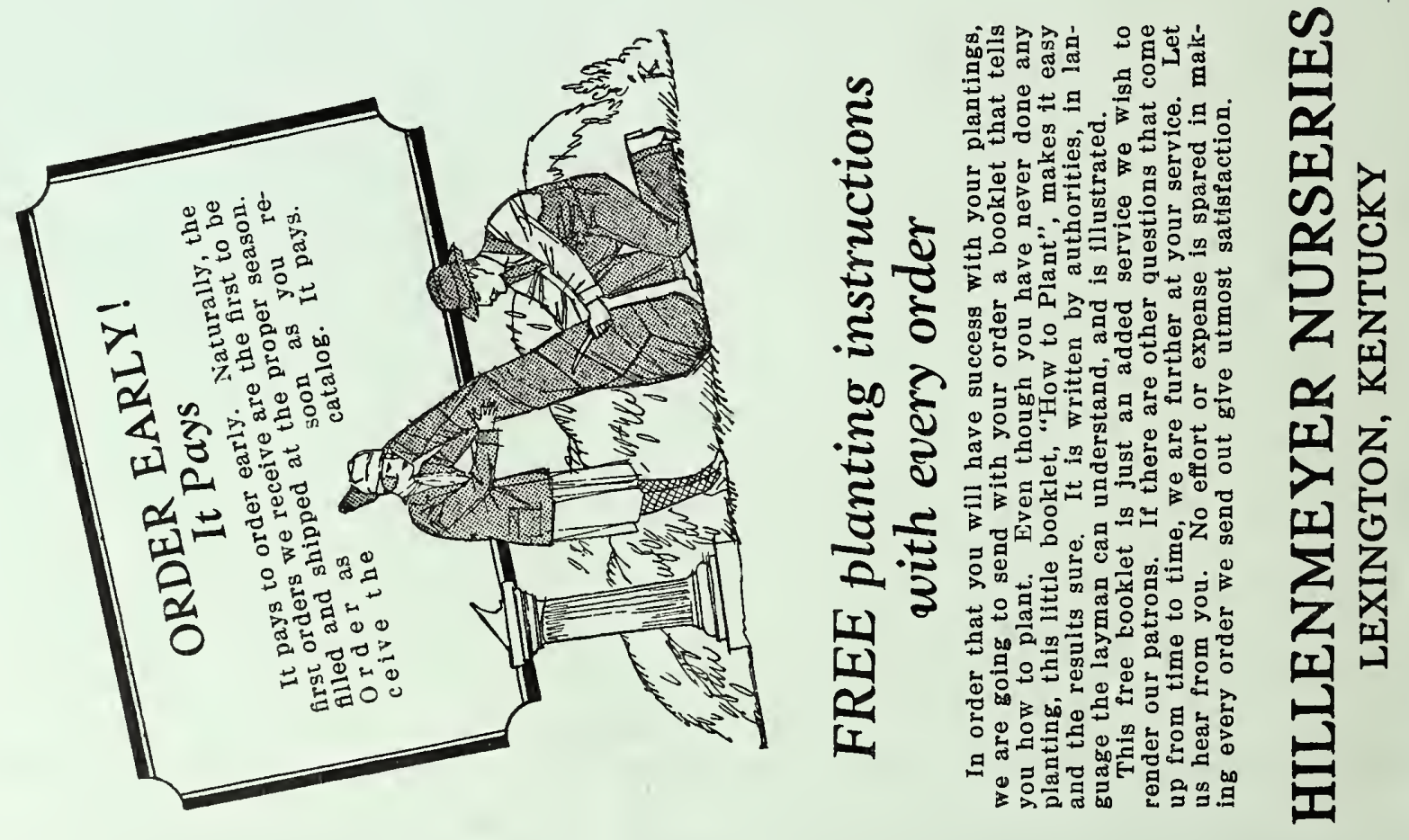


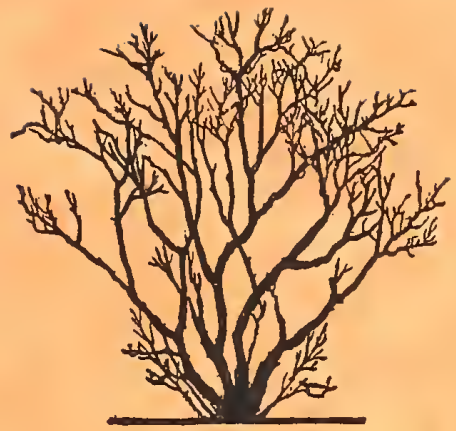

A

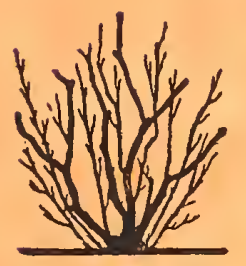

B

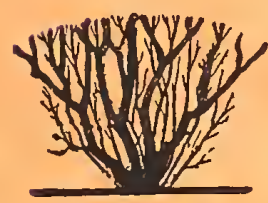

D

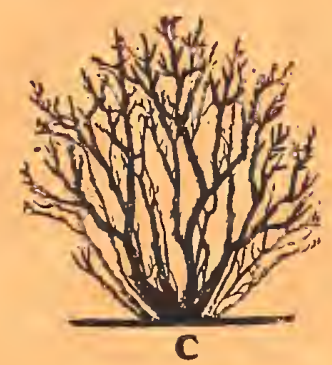

C

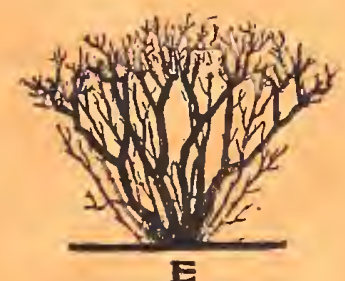

HOW OLD SHRUBS

The object of pruning old shrubs is to keep them shapely and to preserve the blooming wood. The general rule is that those shrubs that bloom in the spring are best pruned within two weeks after they are through blooming. The later blooming things like Hydrangeas, Altheas and terminal blooming varieties are better pruned in the winter or early spring.

With the general idea in mind of cutting out the old and dead wood and the general shaping and renewal of the plant the pictures shown here will be of interest.

A-A familiar, overgrown top heavy shrub, flowers being at the tops on the old wood.

B--The same shrub renewed properly. Note the severity and general shaping of the plant.

C-This same shrub after two seasons growth. Note the even and shapely development.

D-How some "experts" prune. No possible future for such a plant. Compare with B and see the difference.

E-This shows the development after shrub has been pruned as in figure $\mathrm{D}$. Compare this with $\mathrm{C}$ and you will note you have a "two story" plant and very little better than $\mathrm{A}$.

\section{SUCCESS with PLANTS}

Success with plants does not all depend on the nursery stock, nor entirely on the time of the year. You must have your soil in good physical condition and fertile enough so that the plants may grow vigorously.

Upon receipt of the plants do not expose their roots to drying air. If they are to be kept for a time, unwrap the bundle, dip or sprinkle well with water and bury the roots in moist ground (preferably in the shade) to conserve the vitality. If wooded plants are received in shriveled condition, bury the tops for a few days to revive them.

After the tree and shrub holes are filled in, don't leave them to take care of themselves. Note various cultural hints throughout the catalog that tell you how to keep them growing vigorously. The after care until they become established is all important.

Sod may be left around the older trees but when young it is best to keep it cut away. It takes good ground to grow sod and over the roots of young trees it simply robs them of moisture and food. Keep out all weeds and grass until they become established.

Trees and particularly shrubs become mis-shapen. Pruning instructions are given in the catalog or we will help you if asked.

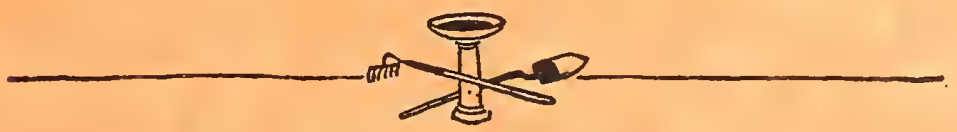

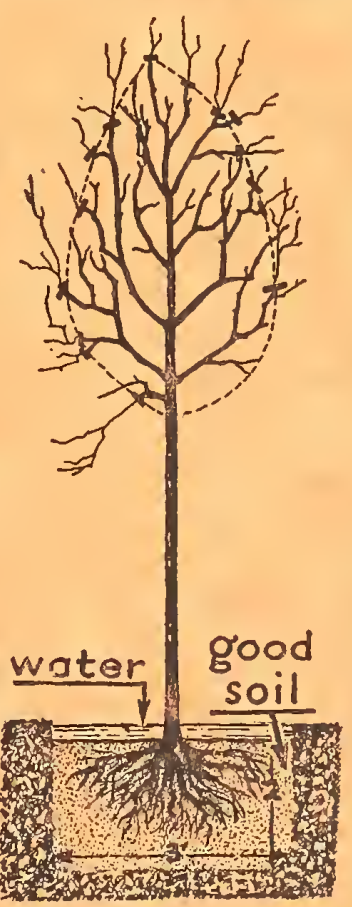

How to Plant Trees

1. Dig hole plenty large.

2. Spread roots out naturally.

3. Use good top soil about roots.

4. Trim back tops as indicated.

5. Settle soil with water. 


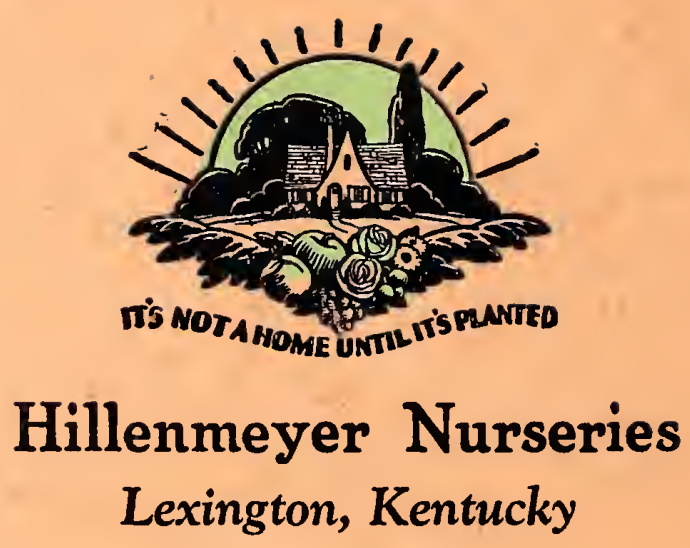

